\title{
Channel Patterns and
}

\section{Terraces of the Loup Rivers}

in Nebraska

GEOLOGICAL SURVEY PROFESIONAL PAPER 422-D

Prepared as part of the program

of the Department of the Interior

for development of the

Missouri River basin
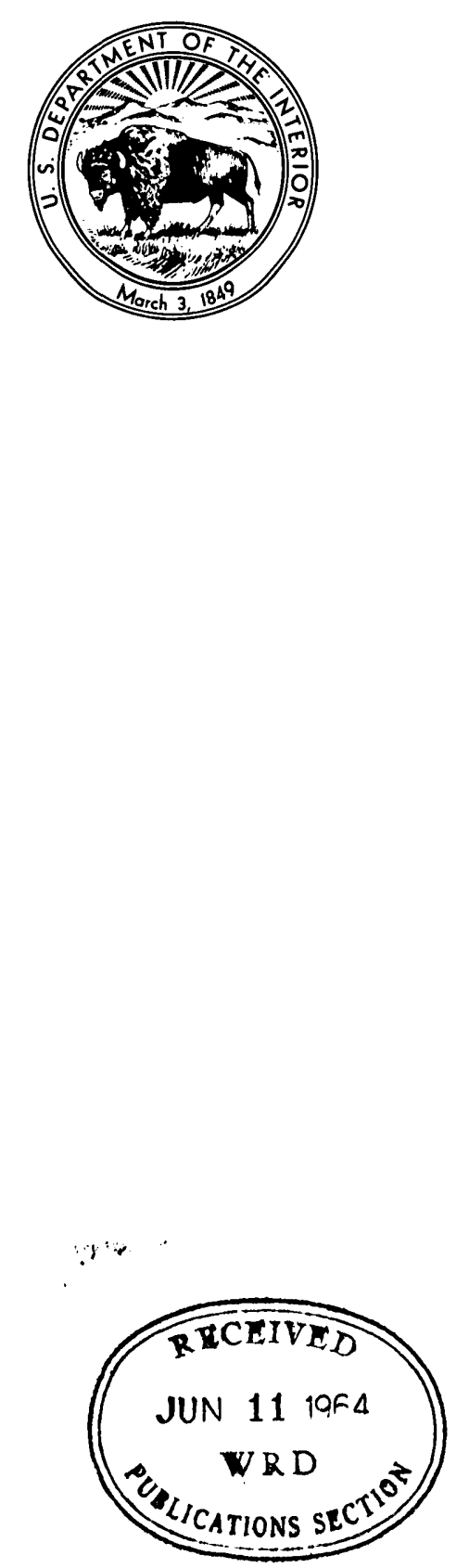



\section{Channel Patterns and}

Terraces of the Loup Rivers

in Nebraska

By JAMES C. BRICE

PHYSIOGRAPHIC AND HYDRAULIC STUDIES OF RIVERS

GEOLOGICAL SURVEY PROFESSIONAL PAPER 422-D

Prepared as part of the program

of the Department of the Interior

for development of the

Missouri River basin

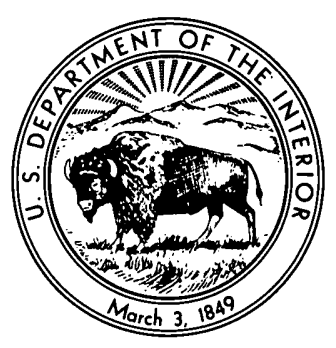

UNITED STATES GOVERNMENT PRINTING OFFICE, WASHINGTON : 1964 


\section{UNITED STATES DEPARTMENT OF THE INTERIOR}

STEWART L. UDALL, Secretary

GEOLOGICAL SURVEY

Thomas B. Nolan, Director

For sale by the Superintendent of Documents, U.S. Government Printing Office

Washington, D.C. 20402 


\section{CONTENTS}

Abstract $\ldots \ldots \ldots \ldots \ldots$

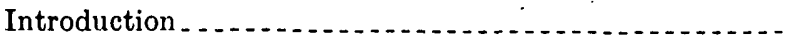

Pleistocene and Recent deposits.....................

North Loup River valley near Elba. . . . . . . . . . . .

North Loup River valley near Burwell ... . . . . . . . .

North Loup River valley downstream from Brewster -

North Loup River valley upstream from Brewster...

South Loup River valley near Cumro... . . . . . . . . .

Summary of Pleistocene and Recent geologic history -

Geologic influences on the longitudinal river profiles.....

Influence of rock resistance ......................

Influence of regional slope and relief ...............

The Middle Loup River at Dunning . . . . . . . . . . . . . .

Hydraulic factors in relation to width . ...........

Hydraulic factors in relation to braiding...........

Hydraulic factors in relation to a confluence........

\begin{tabular}{|c|c|}
\hline Page & The Middle Loup River at Dunning-Continued \\
\hline D1 & Summary of hydraulic factors in relation to channel \\
\hline 1 & pattern \\
\hline 2 & Observations on the formation of sandbars, islands, and \\
\hline 3 & valley flats \\
\hline 5 & Measurement and description of channel patterns \\
\hline 5 & Meandering and sinuosity \\
\hline 6 & Braiding \\
\hline 8 & 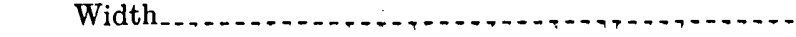 \\
\hline 8 & Channel patterns of the Loup Rivers................ \\
\hline 9 & Relation of selected hydraulic factors to channel pattern \\
\hline 10 & Bank erodibility $\ldots \ldots \ldots$ \\
\hline 12 & Discharge $_{1}$ \\
\hline 14 & Bed material and suspended-sediment concentration. \\
\hline 14 & Water temperature \\
\hline 15 & Longitudinal river slope and valley slope................. \\
\hline 21 & cited ................ \\
\hline
\end{tabular}

Page

D21

23

25

25

27

31

31

32

32

35

37

38

39

40

\section{ILLUSTRATIONS}

Figure 1. Map of Loup River drainage basin

2. General topographic and stratigraphic rela

3. Generalized geologic section along northwest side of Coopers Canyon near Elba and Middle Loup River valleys

4. Cross section in Coopers Canyon near Elba $\ldots \ldots \ldots+\ldots$

5. Geologic section of north side of North Loup River valley near Burwell

6. Stratigraphic diagram of valley fill of the Elba terrace and valley fill of Peporian age exposed in cut bank of North Loup River about 5 miles downstream from Brewster.

7. Cross section of North Loup River valley 6 miles upstream from Brewster

8. Longitudinal river profile, valley profile, and Elba terrace profile, North Loup River

9. Longitudinal river profile and valley profile, Middle Loup River

10. Longitudinal river profile and valley profile, South Loup River

11. Location of sections on a reach of the Middle Loup and Dismal Rivers near Dunning .

12. Cross profiles of Middle Loup River at Dunning

13. Mean depth, mean velocity, local slope, and effective area in relation to effective width at sections $B, C_{2}, E$, and A, Middle Loup River at Dunning

14. Cross profiles of section A, Middle Loup River at Dunning

15. Maximum depth, mean velocity, local slope, and effective area in relation to water width at half mean depth, section A, Middle Loup River at Dunning.

16. Effective area and local slope in relation to effective width for sections upstream and downstream from con fluence of Middle Loup and Dismal Rivers

17. Aerial photograph and tracing of photograph, North Loup River, about 1 mile downstream from gaging station near St. Paul.

18. Small lobe-shaped dunes on

19. Straight reach of North Loup River, same locality as figure 18 .

20. Delineation of meander belt, axis of meander belt, and channel arcs for measurement of sinuosity and symmetry.-

21. Delineation of a reach of the Buyuk Menderes River, Turkey, for measurement of sinuosity and symmetry ....

22. Reaches that illustrate different values of the braiding index $\ldots \ldots$

23. Reaches that illustrate different values of the sinuosity index

24. Longitudinal river profile and valley profile, Calamus River.

25. Diagrammatic relation of sinuosity index to width and bank erodibility, Calamus River

26. Width in relation to mean annual discharge and average maximum daily discharge for different channel patterns.

27. Suspended-sediment concentration in relation to temperature and discharge, sections A, E, and B, Middle Loup River at Dunning

28. Velocity in relation to temperature and discharge, sections $A$ and $E$, Middle Loup River at Dunning........

29. Reach slope in relation to the average maximum daily discharges for meandering and braided reaches........ 


\section{TABLES}

TABLES 1-2. Values of hydraulic factors at-

1. Section A, Middle Loup River at Dunning, Nebr

2. Gaging stations in the Loup River basin 


\title{
CHANNEL PATTERNS AND TERRACES OF THE LOUP RIVERS IN NEBRASKA
}

\author{
By JAMES C. BRICE
}

\begin{abstract}
The North, South, and Middle Loup Rivers drain an area of about 12,000 square miles in central Nebraska. The North and Middle Loup, which rise in the Sandhills, have notably constant discharges because much of their flow is derived from ground water. Moderate sinuosity is characteristic of the South Loup whereas the North and Middle Loup have low sinuosity (except in their upper courses) and tend to be braided. The rivers are bordered by well-defined terraces which are described and interpreted historically as a background for explaining the morphology of the modern rivers. Valley-fill deposits ranging in age from Kansan to Recent are exposed along the rivers, and the fill underlying the youngest major terrace is assigned an age of about 10,000 jears on the basis of three carbon-14 age determinations. The rivers are probably slowly degrading, as the lowest terraces are cut on older fill.
\end{abstract}

Along the Middle Loup near Dunning, a decrease in channel width at constant discharge is accompanied by a decrease in effective area and local slope and by an increase in mean depth and mean velocity. In a braided section, bars submersed to a depth equal to or less than half mean depth arf considered equivalent to emersed bars, and the width of the braided section is expressed as the width of flowing water at half mean depth. The effect of braiding at a wide section is to decrease the width of flowing water, and the changes in hydraulic variables that accompany braiding are similar to the changes that accompany flow from a wide single channel to a more narrow single channel.

The long river profiles are less steep than the long profile of the Great Plains, owing mainly to the sinuosity of the rivers. The Great Plains profile is nearly straight, and the river profiles are straight for most of their length. The slopes of meandering reaches generally are less steep than the slopes of braided reaches of similar discharge, but local slope correlates more closely with the width of flowing water than with any other aspect of channel pattern. The slope of the long river profiles shows little or no change at the confluence of major tributaries, and it does not show any significant correlation with downstream increase in discharge, which is evidently accommodated mainly by changes in cross section. Slope is regarded as a partially independent variable.

Channel patterns are quantitatively described, for geomorphic purposes, by a braiding index and a sinuosity index. The greater sinuosity of the South Loup, in comparison with the lower courses of the North Loup and Middle Loup, is attributed to the higher concentration of silt and clay in its suspended load. Probably, the silt and clay promotes sinuosity as it becomes incorporated in bank materials and increases the cohesiveness of banks. Within the Sandhills, the North
Loup, Middle Loup, and their tributaries tend to be sinuous despite a very low concentration of silt and clay in the suspended load; however, swamp vegetation is common along the stream courses, and it probably promotes sinuosity by increasing bank resistance. In general, where banks are of sand and easily erodible, wide shallow channels tend to develop. Braiding takes place in wide shallow channels by the growth and stabilization of longitudinal sandbars, which probably originate from breaching of transverse bars and dunes. Sinuous reaches are generally narrower than braided or straight reaches of similar discharge. Width, although highly variable locally, increases downstream approximately as the 0.5 power of bank-full discharge. The downstream relation of width to discharge is affected by a downstream increase in variability of discharge.

\section{INTRODUCTION}

The Loup River basin (fig. 1) occupies all of central Nebraska. The part of the basin considered in this report has an area of about 12,000 square miles. Of this area, about 4,500 square miles is mantled with loess and contributes directly to surface runoff, and about 7,500 square miles is mantled with dune sand and does not contribute directly to surface runoff. (See fig. 1.) Annual rainfall averages about 20 inches in the eastern part of the basin and about 15 inches in the western part.

The purposes of this report are to describe the channel patterns of the Loup Rivers quantitatively and to determine the factors that have had the greatest influence on the development of these patterns. Among the factors considered were the gradients and deposits of ancestral rivers. Terraces and valley-fill deposits of late Wisconsin and Recent age were studied, and the geologic history of the Loup Rivers was outlined. River widths and channel patterns were measured on aerial photographs, and long profiles were prepared from topographic maps. Detailed measurements on the Middle Loup and Dismal Rivers-made by the Geological Survey in connection with investigations of sediment transport-were analyzed and related to channel pattern.

Fieldwork, which was done in the summer of 1958, consisted mainly of an investigation of terraces and terrace deposits, and the movement of dunes and bars in the river channels was also observed. 
Rivers of the Loup basin are especially suitable for a study of channel patterns and other aspects of river morphology. Different reaches of the North and Middle Loup Rivers represent meandering, braided, straight, or sinuous channel pattems; and the South Loup River is meandering. Gaging stations are well distributed along the rivers (see fig. 1), and the period of record for most of these stations is adequately long. The North and Middle Loup Rivers have in their upper courses notably constant discharges because most of their flow is derived from ground water rather than from surface runoff. Reasonably complete data on suspended-sediment load are available, and investigations of total load have been made in a turbulence flume at Dunning. Topographic maps published between 1951 and 1955 are available for most of the basin; these have a scale of $1: 24,000$ and a contour interval of 10 feet. Other parts of the basin are covered on recently published topographic maps that have a scale of 1:62,500 and a contour interval of 20 feet. Aerial photographs, taken in the 1930's and again in the 1950's, are available.

This report was written under the direction of D. M. Culbertson, district engineer at Lincoln, Nebr. Three carbon-14 age determinations were made by Meyer

\section{OF THE LOUP RIVERS IN NEBRASKA}

Rubin. B. R. Colby, M. Gordon Wolman, and S. A. Schumm critically read the manuscript and offered many helpful suggestions.

\section{PLEISTOCENE AND RECENT DEPOSITS}

Pleistocene stratigraphic units that were distinguished in the Loup River basin are shown in figure 2. The basin is underlain by the Ogallala Formation (Pliocene), which crops out at widely scattered localities along the sides of the main valleys. The Ogallala is composed of alluvial gravels, sands, and silts, from which much of the Pleistocene valley fill has been derived. The oldest Pleistocene deposits observed during the present investigation are correlated with the Kansan Glaciation on the basis of their stratigraphic position beneath two buried soils, of which the upper was identified as the Sangamon and the lower as the Yarmouth. The Loveland Formation (Illinoian) on the upland consists of dune sand and loess which commonly are found in alternate layers. Outcrops of the Sangamon soil are common along the valleys of minor tributaries and along roadcuts in the upland. Along the main valleys, the Sangamon soil is developed on silt, sand, or gravel that is presumably of Illinoian age.

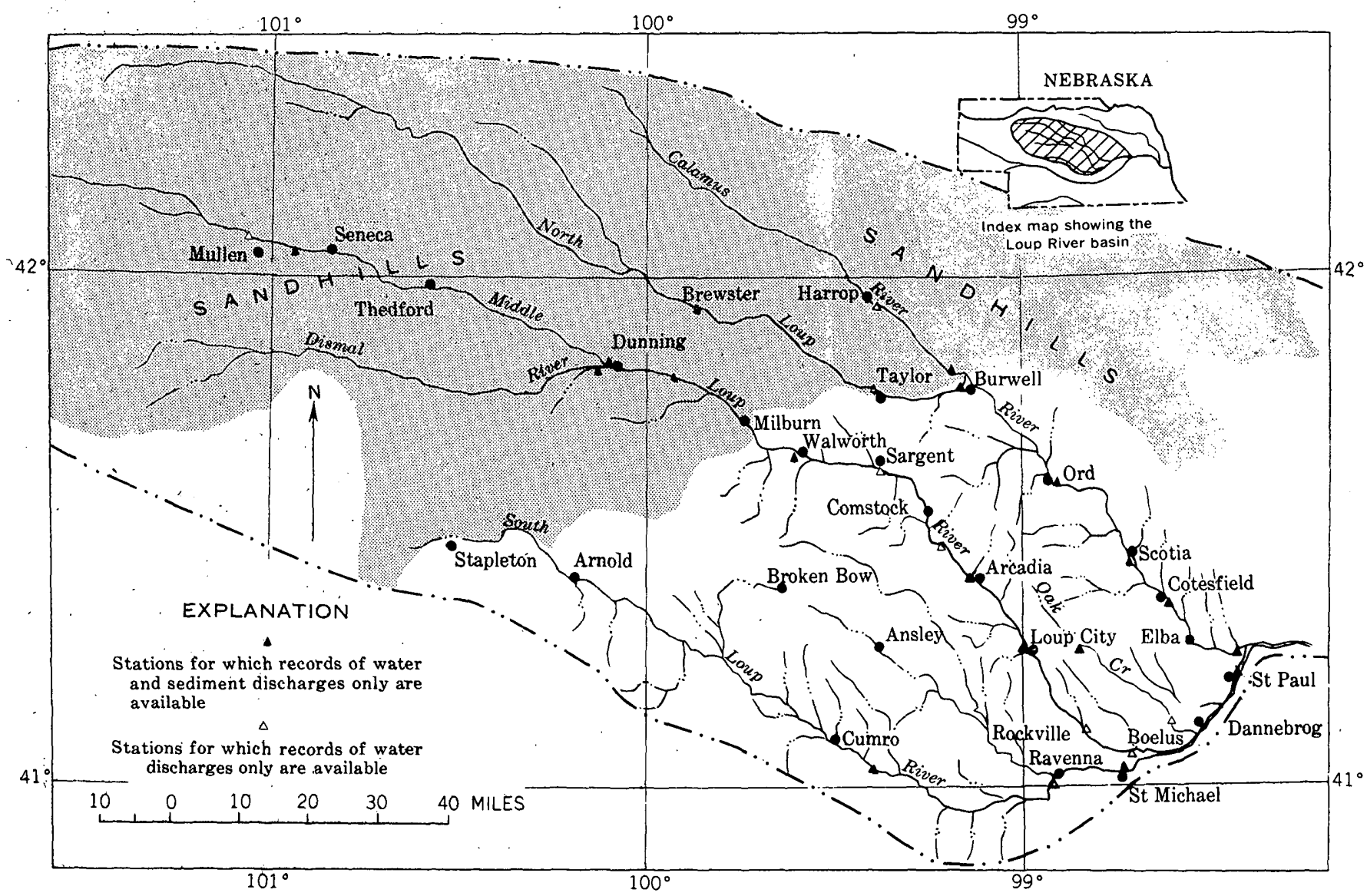

FIGURE 1.-Map of Loup River dralnage basin. 
Peorian Loess of Wisconsin age mantles the southern half of the Loup River basin. The upland loess extends down the valley sides and merges with a contemporaneous valley fill of Peorian age which consists mostly of silt in minor tributary valleys and of silt, sand, and gravel in the main valleys. (See figs. 2, 3, 4.) The physiographic expression of this valley fill of Peorian age, here called the Kilgore terrace, has been mostly obliterated by erosion, but a few distinct remnants of the Kilgore terrace can be seen along the South Loup River near Cumro.

The most conspicuous and extensive terrace in the main valleys stands $20-40$ feet above river level, and many broad, flat remnants of this terrace occur along the lower 100 miles of the North and Middle Loup Rivers. This terrace is here called the Elba terrace because the town of Elba is built on its surface and because the underlying valley fill is well exposed in the walls of a canyon southeast of Elba. (See figs. 3, 4.) Carbon-14 age determinations indicate that deposition of the valley fill of the Elba terrace began about 10,000 years B.P. Several minor terrace deposits of late Recent age stand along the main streams at heights ranging from a few feet to 15 feet above river level.

\section{NORTH LOUP RIVER VALLEY NEAR ELBA}

About 0.6 mile southeast of Elba, the Elba terrace is deeply trenched by an intermittent stream that descends from the upland and flows in a canyon northwestward across the terrace and into the North Loup
River. (See fig. 3.) Most minor tributaries of the river, both intermittent and permanent, have cut shallow valleys into the terraces that border the river; in the canyon southeast of Elba is one of the few deep cross sections to be found. This canyon, although unnamed on the Elba quadrangle sheet, was called Coopers Canyon by Miller and Scott (1955), and this name is used here. The entrenchment of Coopers Canyon is perhaps explained by the fact that the canyon meets the river on the outside of a meander bend where the meander has made a steep cut into the Elba terrace about 30 feet above river level. Successive shifts of the river against the mouth of the intermittent stream probably formed a succession of headcuts that advanced rapidly upstream during times of heavy runoff and thus formed the canyon. Because the history of Coopers Canyon is not representative of stream history in the Loup River basin, the minor late Recent terrace deposits in the canyon have no regional significance.

The valley fill exposed in the nearly vertical walls of Coopers Canyon was described in detail by Miller and Scott (1955). The thickness of exposed valley fill is about 40 feet, of which the lower $12-15$ feet is white crossbedded sand and the upper 23-25 feet is silt. Within the silt are several humic zones, which Miller and Scott interpreted as soils, developed during different interglacial episodes of the Pleistocene. The lowest and most conspicuous of these humic zones was named by Miller and Scott the Coopers Canyon gley soil. They attributed this soil to weathering during

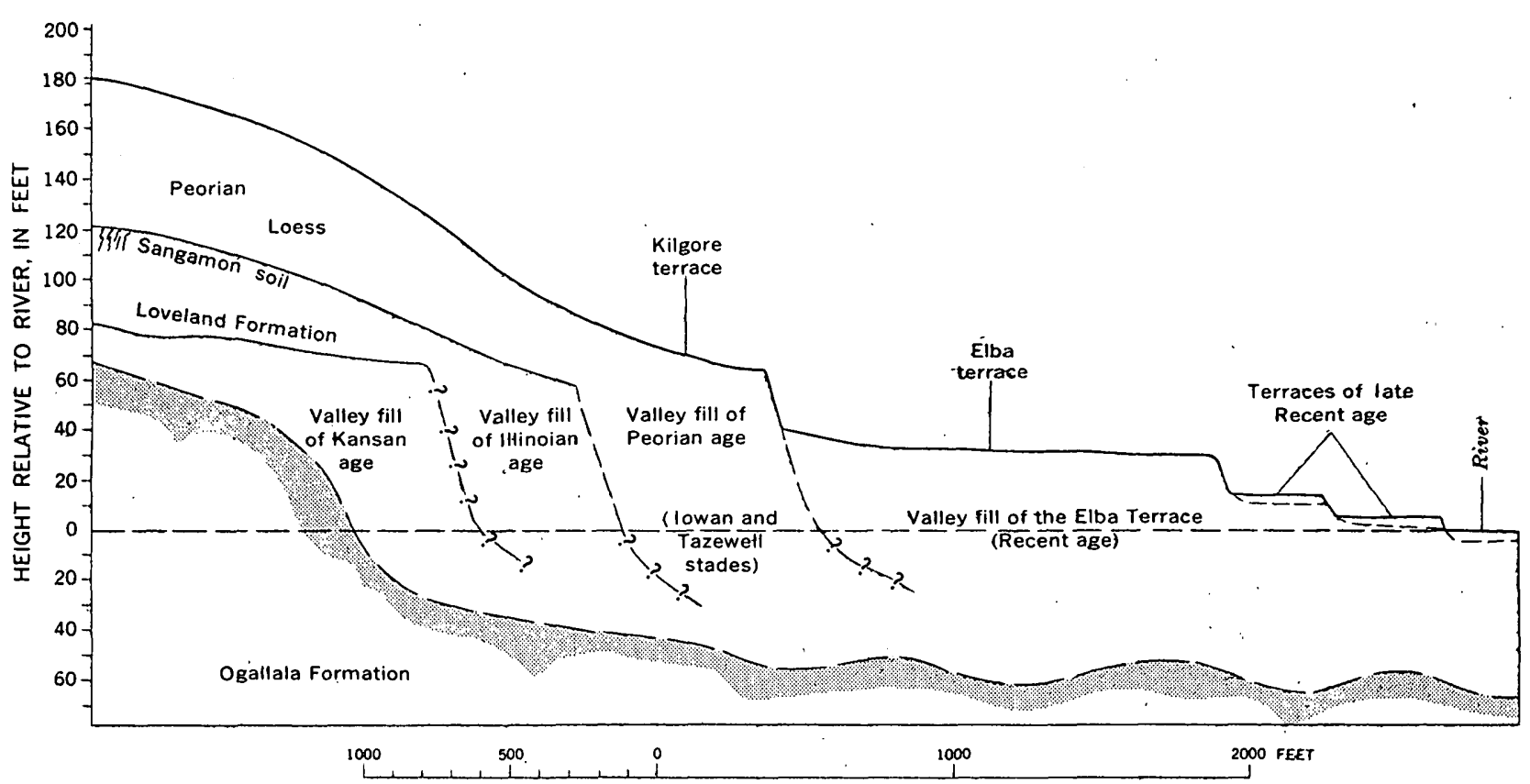

Froure 2.-General topographic and stratigraphic relations of valley flls in the North, South, and Middle Loup River valleys. Dashed lines are inferred contacts. 


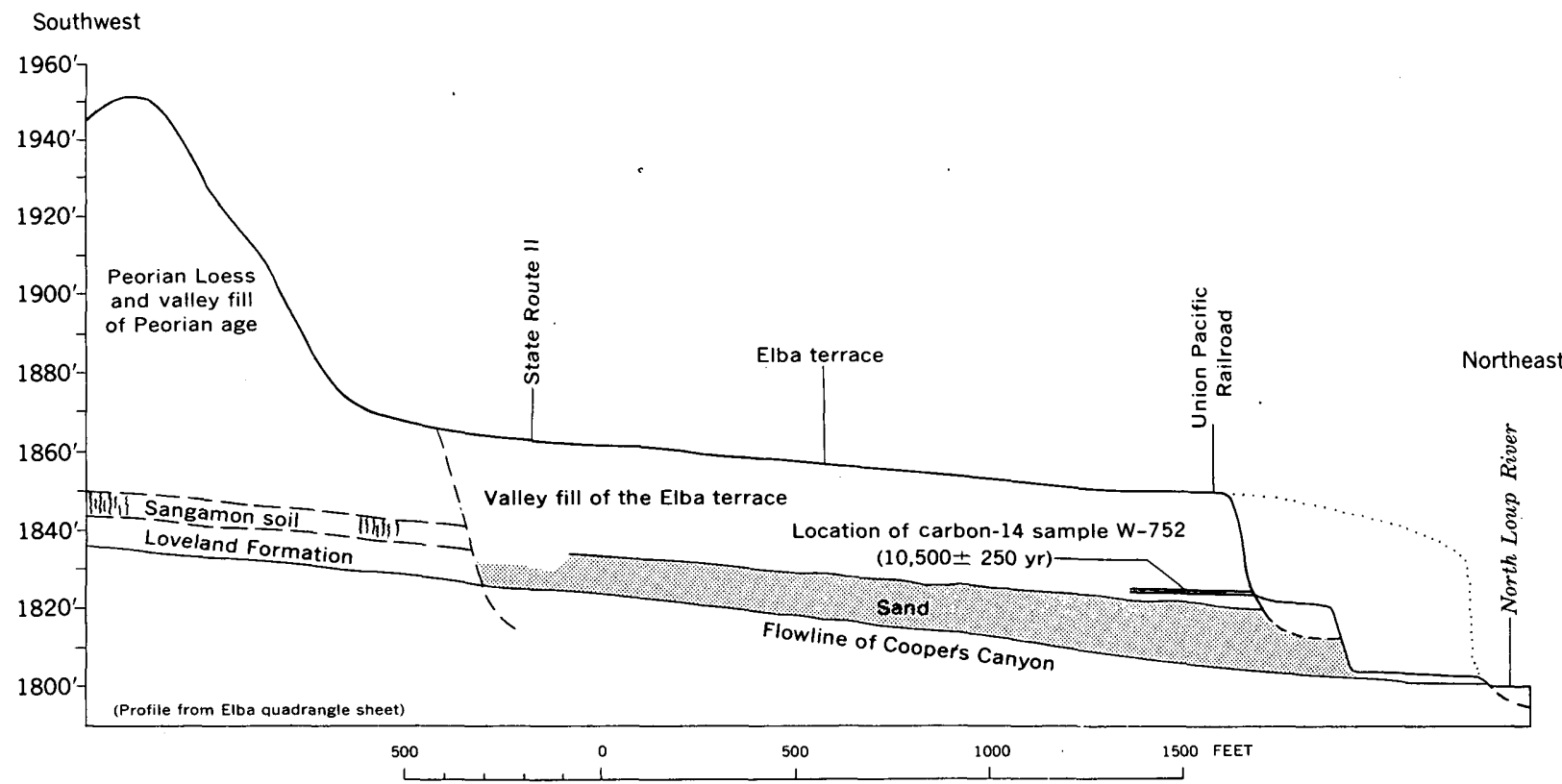

Figure 3.-Generallzed geologic section along northwest side of Coopers Canyon near Elba. Dotted line Indicates Elba terrace profile just southeast of canyon. Dashed lines are inferred contacts.

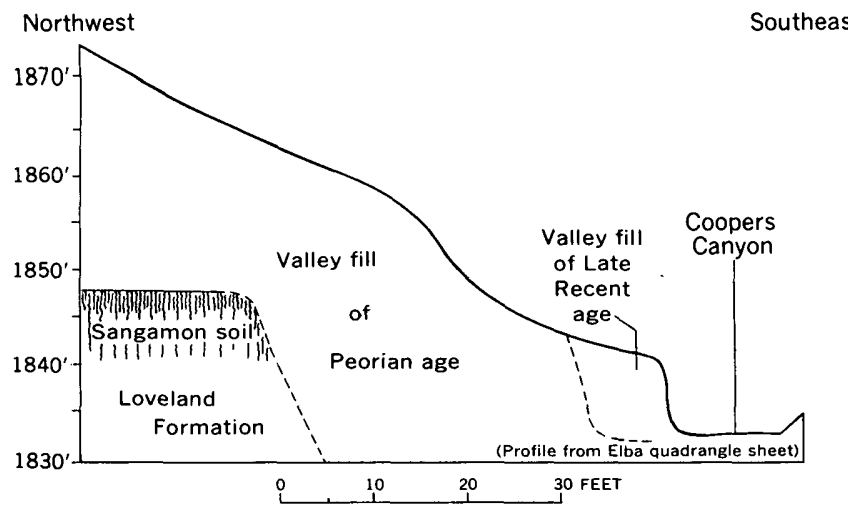

Frgure 4.-Cross section in Coopers Canyon near Elba. Section is 1,100 feet upstream from bridge on State Route 11.

the entire interval between the end of the Kansan Glaciation and the beginning of the Cary Stade of the Wisconsin Glaciation.

In 1958 the Coopers Canyon gley soil was examined in detail by the writer at several places along the canyon walls, particularly on the northwest wall 100 feet upstream from the railroad bridge that crosses the canyon. Here the soil consists of a band of gray silty clay about 1 foot thick underlain by a band of calcareous silty sand in which snail shells are so abundant that they give the sand the appearance of a coquina. A collection of large and apparently unaltered snail shells from the calcareous silty sand yielded a carbon-14 age of $10,500 \pm 250$ years (U.S. Geol. Survey lab. No. W-752). As the snail-bearing layer is only about 1 foot above the sand that forms the base of the exposure and as the crossbedding of the sand indicates rather rapid deposition, the sand probably is not much older than 10,000 years. Miller and Scott (1961, p. 1284) published a revision of their previous interpretation (1955) of stratigraphy in Coopers Canyon. They now consider all the alluvium and soils in the high terrace (here named the Elba terrace) as "*** younger than the Two Creeks interstadial."

Along Coopers Canyon upstream from the point at which the canyon enters the upland, the Elba terrace is absent, probably because it has been removed by lateral erosion. The sides of the canyon are composed of Peorian Loess, of valley fill of Peorian age, and of Loveland Formation overlain by Peorian Loess; set against these sides are minor valley fills younger than the Elba. About 1,100 feet upstream from the bridge where State Route 11 crosses Coopers Canyon, the Sangamon soil is well exposed in the north side of Coopers Canyon; the top of the soil is about 15 feet above the canyon bottom, and at one end of the exposure the soil is truncated by valley fill of Peorian age. (See fig. 4.) The appearance of the Sangamon soil at this locality is typical of its general appearance throughout Nebraska, except that no $\mathrm{C}_{\mathrm{ca}}$ horizon has developed. The Sangamon soil that has developed in upland areas is commonly a soil complex (some of the horizons are repeated vertically); and the 
Sangamon soil that has developed on valley fills, like the Sangamon soil in Coopers Canyon, may represent only part of this complex. The Sangamon soil in Coopers Canyon consists of a darkgrayish-brown (10YR 4/2 moist) humic zone 2 feet thick underlain by a zone of clay enrichment 6 feet thick. The parent Loveland Formation consists of light-yellowish-brown (10YR 6/4 moist) silt underlain by sand of the same color.

\section{NORTH LOUP RIVER VALLEY NEAR BURWELI}

Pleistocene deposits ranging in age from Kansan to Wisconsin are well exposed in the sharply dissected valley side of the North Loup River 2 miles north of Burwell, Nebr. In the NE $1 / 4 \mathrm{NE} 1 / 4$ sec. 11, T. $21 \mathrm{~N}$, R. 16 W., the Sangamon soil forms a conspicuous band on a steep-sided ridge (see fig. 5); and ashy silts crop out at the base of this ridge. Although the Yarmouth soil does not crop out in this ridge, it is well exposed 700 feet west of the ridge; there it is developed on about 4 feet of ashy silt. The ashy silt is underlain by gravel which has been excavated for road building. Although the thickness of the Peorian Loess is only about 20 feet at this locality, it increases rapidly to about 70 feet a few hundred yards to the north.

About 3 miles east of Burwell, the uplands north of North Loup River is trenched by Jones Canyon, which is steep sided and deep. In the upper reaches of this canyon, in the NE1/4 sec. 9, T. 21 N., R. 15 W., a thickness of 90 feet of Peorian Loess is exposed; the total thickness of the Peorian here is even greater, as the base is not exposed.

\section{NORTH LOUP RIVER VALLEY DOWNSTREAM FROM BREWSTER}

The valley fill of the Elba terrace and the valley fill of Peorian age are well exposed in a deep cut on the outside of a meander bend of the North Loup River near the center of sec. 5, T. 22 N., R. 21 W., about 5 miles downstream from Brewster. (See fig. 6.) A peat bed within the valley fill of the Elba terrace abuts sharply against both sides of a residual ridge of valley fill of Peorian age, and a radiocarbon determination on a sample of the peat (U.S. Geol. Survey lab. No. W-755) yielded an age of $8,400 \pm 250$ years B.P. The surface of the Elba terrace, which is locally buried by dune sand, stands about 20 feet above the water level of the river. A lower terrace surface, which stands about 10 feet above water level, has been cut on valley fill of the Elba terrace; the peat bed within the Elba extends continuously beneath this lower surface.

The valley fill against which the valley fill of the Elba terrace abuts is 45 feet thick and consists of poorly sorted sand and gravel throughout; it is identified as valley fill of Peorian age only on the basis of stratigraphic and topographic position. Rapid deposition of this. valley fill is indicated by the absence of buried humic zones, the absence of clay or peat beds, and the presence of large-scale crossbedding in the gravel beds.

The following stratigraphic section of dune sand and valley fill of the Elba terrace applies to the cutbank shown on the left side of figure 6 , near the con-

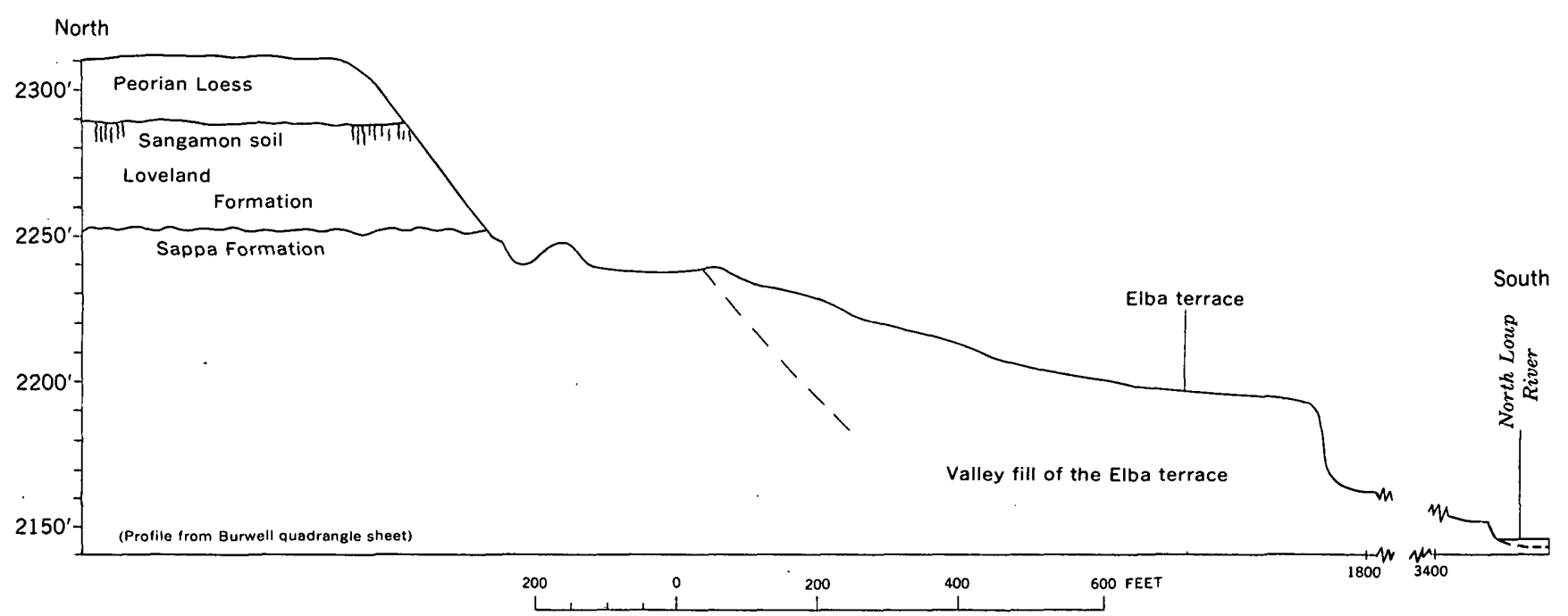

Froure 5.-Geologic section of north side of North Loup River valley near Burwell. 
tact between the Elba. valley fill and valley fill of Peorian age:

Measured section of Elba Terrace about 5 miles downstream from Brewster

Sand, fine-grained, white, aeolian . .....

Humic zone in silty, clayey sand; black (10YR 2/1 moist)

Sand, medium- to fine-grained, yellowish-

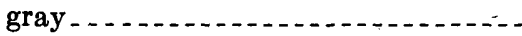

Clay, sandy, medium-gray

Humic zone in sand; black (10YR 2/1 moist)

Sand, light-gray; mottled by filled worm burrows . . . . .

Sand, medium- to fine-grained, yellowish-

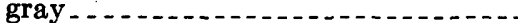

Sand interbedded with peaty clay and sand. Unit grades horizontally into bed of peat $3 \mathrm{ft}$ thick which contains abundant upright Equisetum stems ...

Sand, medium-grained, white; contains laminae of black clay

Sand and gravel, poorly sorted, crossbedded. ................................. at $41 \mathrm{ft})$

Water level of North Loup River

\section{NORTH LOUP RIVER VALLEY UPSTREAM FROM BREWSTER}

In the vicinity of Pitt Bridge, which crosses the North Loup River 6 miles upstream from Brewster, the Elba terrace forms an extensive flat about 30 feet above water level on the south side of the river, and a succession of lower terraces forms flats on the north side of the river. The most extensive of these lower terraces stands about 12 feet above water level, and other less extensive terraces stand at 4 feet and at 2 feet above water level. About 1,000 feet downstream from the bridge, a section across the 4-foot and the 12foot terraces is exposed in a meander cut. A peat bed crops out near water level under the 4-foot terrace surface and extends continuously under the 12-foot terrace surface. (See fig. 7.) The 4-foot terrace was evidently cut on the fill that contains the peat bed. The age of $9,000 \pm 250$ years B.P., obtained on a log from the peat bed (U.S. Geol. Survey lab. No. W750 ), indicates that the fill on which both the 4-foot and the 12-foot terraces are cut is the valley fill of the Elba terrace. Where W-750 was collected, the fill underlying the 12 -foot terrace is as follows:

Measured section of fill underlying 12-foot terrace 6 miles upstream from Brewster

Surface soil, very pale brown $(10 Y R 8 / 4$ moist); weak humic zone developed on fine-grained sand .................

Sand, fine-grained, white; mottled by - numerous filled worm burrows in upper part

Humic zone, dark-gray $(10 Y R \quad 4 / 1$ moist) ; developed on fine-grained sand . Sand, medium- to fine-grained, white, crossbedded; contains streamers of small pebbles and a few thin layers of dark clay ............................

Peat, dark-brown, rubbery; contains abundant Equisetum stems and a few small logs.......................

Sand, medium-gray, silty ............ (Water level of river at $11 \mathrm{ft}$ )

$\begin{array}{rr}\text { Depth (feet) } & \begin{array}{c}\text { Thickness } \\ \text { (feet) }\end{array} \\ 0-1.2 & 1.2 \\ & \\ 1.2-3.2 & 2.0 \\ \text { 3. 2-3.5 } & .3\end{array}$

3. $5-9.5 \quad 6.0$

9. 5-10.5 $\quad 1.0$

10. $5-11.0 \quad .5$

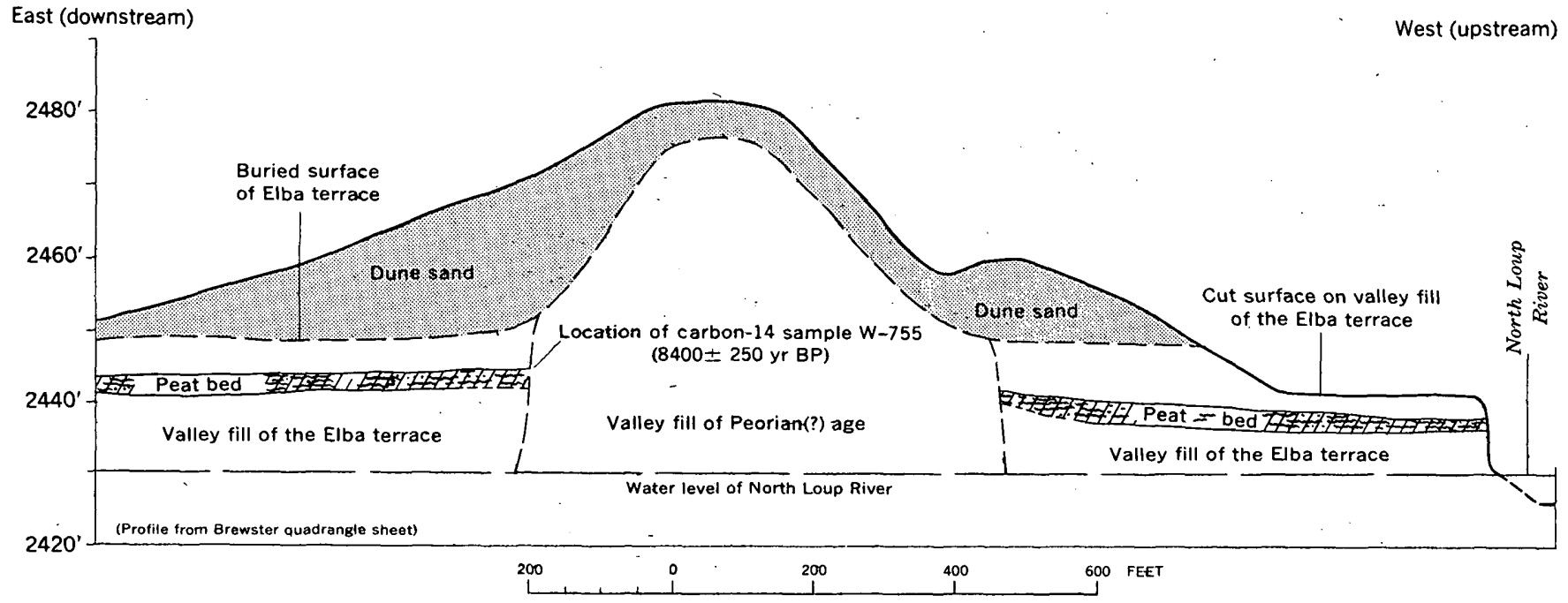

Figure 6.-Stratigraphlc diagram of valley fll of the Elba terrace and valley fll of Peorian age exposed in cut bank of North Loup River about 5 miles downstream from Brewster. 
PHYSIOGRAPHIC AND HYDRAULIC STUDIES OF RIVERS

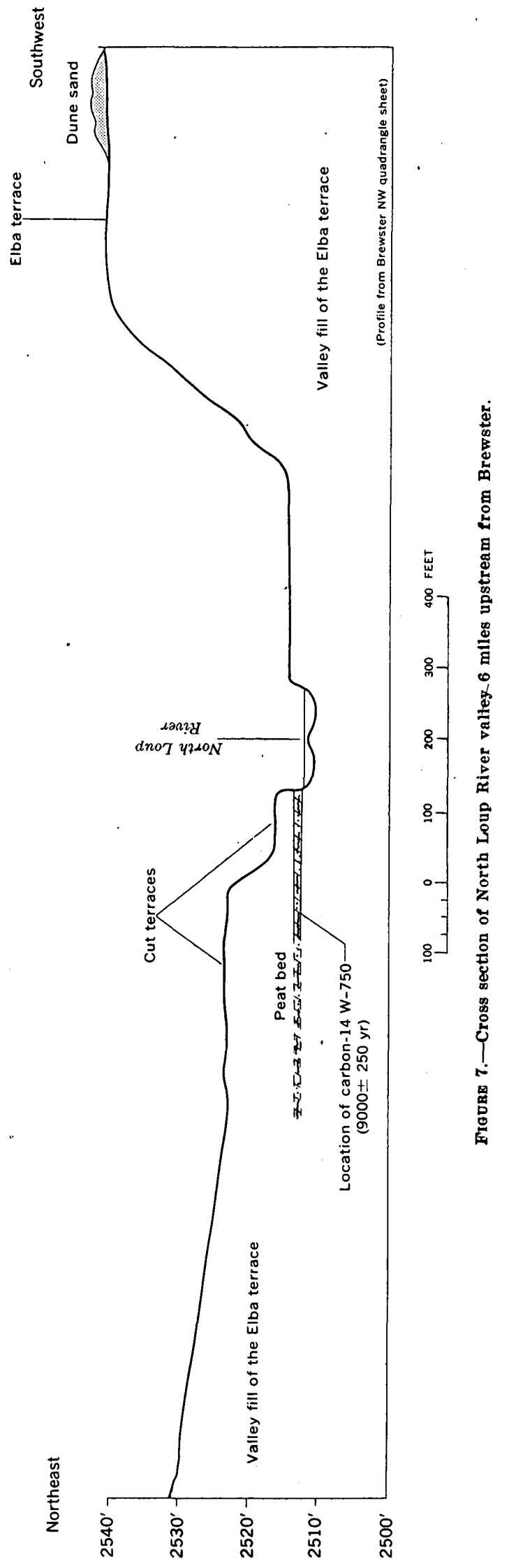




\section{SOUTH LOUP RIVER VALLEY NEAR CUMRO}

An extensive terrace standing 30-40 feet above river level in many places along the South Loup River is correlated with the Elba terrace of the North Loup River on the basis of height, degree of dissection, and stratigraphic relation with older valley fills. The fill of the Elba terrace is well exposed along the South Loup River at several localities upstream and downstream from Cumro. Silt and fine sand are the main constituents of the fill; however, the proportion of these is not uniform from place to place, and no uniform gradation from coarse sediment at the base of the fill to fine sediment toward the top was observed.

Along the South Loup River near Cumro, remnants of a terrace standing $60-80$ feet above river level were observed. This terrace is here called the Kilgore terrace because sections of the terrace fill and remnants of the terrace surface can be seen along Kilgore Creek, which is about 3 miles downstream from Cumro. Where sections of the fill underlying the Kilgore terrace are exposed along the South Loup River, as at Satoria, the fill consists mainly of waterlaid sand and silt. The fill underlying the Kilgore terrace is considered to be valley fill of Peorian age, contemporaneous with Peorian Loess on the upland, because the Kilgore terrace slopes up and merges with the upland without any break in topography. Moreover, the fill underlying the Kilgore terrace is the only fill observed that is older than the valley fill of the Elba terrace but younger than the Loveland Formation.

Minor terraces at various elevations below the Elba terrace surface appear in the vicinity of Cumro and generally along the South Loup River. These minor terraces could not be correlated from place to place along the river, and their variability in height above river level suggests that they are cut terraces rather than fill terraces. Downcutting by the South Loup River is indicated by the presence of abandoned channels that stand at different heights above the present river level and below the level of the Elba terrace.

\section{SUMMARY OF PLEISTOCENE AND RECENT GEOLOGIC HISTORY}

The valleys of the Loup Rivers were originally incised into the Ogallala Formation prior to Kansan time, perhaps as early as the late Pliocene. Exposed Kansan deposits are sparse along the present valleys, and the rivers have probably shifted their courses greatly during the Pleistocene. The valley fill of Kansan age at Burwell consists mainly of gravel and sand, and it filled the bedrock valleys to a height of about 80 feet above present river level. The valley fill of Kansan age was probably incised before depo- sition of the valley fill of Illinoian age, the top of which stands about 60 feet above present river level; however, no stratigraphic evidence of such incision was found.

After the development of the Sangamon soil, the main valleys were incised at least to the present river levels, and the upland was deeply gullied. Incision of the main valleys is indicated by the position of valley fill of Peorian age, which crops out near the level of the present rivers. At upland roadcuts, steep-sided hillocks cut in the Loveland Formation and buried by the Peorian Loess can be distinguished. The hillocks commonly are capped by the Sangamon soil, and on their buried slopes detached slabs of Sangamon soil are commonly incorporated in the base of the Peorian. The origin of these slabs is puzzling, but probably they were detached by erosion from near the top of the slope and then, after sliding some distance downslope, were incorporated in the accumulating Peorian Loess. The Peorian Loess accumulated to a maximum depth of about 50 feet on the upland near Ord and to a depth of about 90 feet on the upland near Burwell, and the valley fill of Peorian age accumulated in the main valleys to a height of 60-80 feet above the present river level. Scattered remnants of the surface of the valley fill of Peorian age are preserved, and this surface is here called the Kilgore terrace.

Deposition of the Peorian Loess and valley fill was followed by deep incision in the main valleys, inasmuch as the surface of the next younger valley fill (that of the Elba terrace) stands about 30 feet below the surface of the Kilgore terrace and the thickness of the valley fill of the Elba terrace is at least 30 feet. This incision in the main valleys was accompanied by extensive gully and drainage development in the upland. Nearly all the present tributaries, except for gullies of late Recent age, are bordered by remnants of the Elba terrace and, therefore, existed before deposition of the valley fill of the Elba terrace.

Deposition of the valley fill of the Elba terrace in the valleys of intermittent tributaries was accompanied by extensive grading of the valley sides, which slope smoothly down to the surface of the fill. Along the largest permanent streams, grading of valley sides is less notable, probably because these streams continued to steepen their valley sides by lateral planation during deposition of the valley fill of the Elba terrace. Minor buried soils are common in the valley fill of the Eliba terrace, particularly in the upper part; but the number, degree of development, and position of these soils vary from place to place. The soils, which have poorly developed profiles, probably formed during short intervals, of perhaps no more than a few hundred years each, when deposition of the valley fill 
of the Elba terrace was temporarily halted. The lateral extent of each soil appears to be local rather than general; differences in soil characteristics over short lateral distances probably resulted from differences in drainage that existed during soil development. Close spacing of minor soil and humic zones in the upper part of the valley fill of the Elba terrace suggests slow and intermittent deposition of this upper part. Three carbon-14 age determinations on valley fill of the Elba terrace along the North Loup River indicate that deposition began somewhat earlier than 10,500 years B.P. and was still in progress 8,000 years B.P. Development of buried soils in the upper part of the fill and grading of valley-side slopes must have required a long period of time; hence, incision of the fill and dissection of the associated graded slopes are assigned a more recent date, perhaps 2,000 or 3,000 years B.P.

Late Recent terrace deposits, ranging in height from a few feet to 15 feet above present river level, are attributed to lateral cutting rather than to filling because they are mainly underlain by valley fill of the Elba terrace. The Loup Rivers have been degrading their channels continuously during late Recent time, perhaps for the past 2,000 or 3,000 years, and are probably degrading their channels at present.

Dune sand covers much of the Loup River basin; however, time did not permit a study of the dunes. H. T. U. Smith (1955) published a brief description of the development of dune forms in the Nebraska Sandhills. The general northwest-southeast trend of the dune ridges shows clearly on aerial photographs, as do the remarkable longitudinal furrows that run the full length of many dune ridges along their crests. The dune ridges are roughly parallel to the prevailing wind direction. The troughs between ridges and the furrows on top of the ridges are probably erosional in that both begin as rounded blowouts and progress downwind, killing the grass in front of them and leaving behind them a furrow, much as a finger leaves behind a furrow as it is pushed across the surface of sand. Mantling of the Peorian Loess by dune sand is conspicuous along the north side of the North Loup River near Burwell; therefore, the Sandhills must have been extended considerably in this vicinity since Peorian time. The Peorian Loess is, however, remarkably free of interbedded dune sand.

\section{GEOLOGIC INFLUENCES ON THE LONGITUDINAL RIVER PROFILES}

The slope and direction of flow of a river are initially determined by the geologic setting in which the river becomes established. Geologic setting includes not only the resistance of the rocks traversed by the river but also the regional slope of the land surface. For modern rivers that flow in valleys made by ancestral rivers, geologic setting includes the gradients and deposits of the ancestral rivers. Rubey $(1952$, p. 135) pointed out that a river flowing on a predetermined gradient may more nearly or more readily attain equilibrium by the development of a wide, shallow - cross section than by the development of a flatter gradient. Development of a flatter gradient might be inhibited by resistant consolidated rock or by gravel beneath the river bed. Development of a wide, shallow cross section would be promoted by easily erodible river banks.

Geologic influences on the long profile of a river can be evaluated by relating the river profile to the regional slope, to the valley gradients of ancestral rivers, and to the distribution of different rock units traversed by the river. Inasmuch as the Loup Rivers are flowing mainly on the deposits (valley fill of the Elba terrace), of an ancestral river, the modern rivers have been influenced both by the lithology of the fill of the Elba terrace and by the gradient of the Elba surface. Similarly, the ancestral Loup Rivers were doubtless influenced by the regional slope of the Great Plains and by the lithology of the underlying Ogallala Formation.

Longitudinal river profiles and valley profiles were prepared for the North Loup (fig. 8), Middle Loup (fig. 9), and South Loup (fig. 10). Profiles of the North Loup from altitudes of 1,745 to 2,500 feet were measured on Geological Survey topographic maps, scale $1: 24,000$, contour interval 10 feet; and from altitudes of 2,500 to 3,200 feet, on Geological Survey topographic maps, scale 1:62,500, contour interval 20 feet. Profiles of the Middle Loup from altitudes of 1,7452,560 feet were measured on 1:24,000-scale Geological Survey topographic maps having a contour interval of 10 feet; and from altitudes of 2,560-3,300 feet, on 1:62,500-scale Geological Survey topographic maps having a contour interval of 20 feet. Profiles of the South Loup from altitudes of 1,880 to 1,982 feet were measured on 1:24,000-scale Geological Survey topographic maps having a contour interval of 10 feet; and from altitudes of 1,982 to 3,000 feet, on $1: 250,000$-scale Army Map Service maps having contour intervals 50 or 100 feet. For the river profiles, horizontal distances along the stream were measured with a map measurer. For the valley profiles, horizontal distances were measured along a line drawn through the inflection points of curves in the stream, and altitudes were taken on the streambank at an inflection point. Between any two points of given elevation, the ratio of valley slope to stream slope is a measure of the 
sinuosity of the stream; indeed, sinuosity may be defined in this way (Lane, 1957, p. 98). The regional slope of the Great Plains, which is shown for comparison with the profiles, was measured on Army Map Service maps (scale, 1:250,000; contour interval, $100 \mathrm{ft}$ ) over the same section of the Great Plains as that crossed by the Loup Rivers. A straightedge was laid perpendicular to the trend of the contour lines that indicate the regional slope of the plains. The prevailing elevation of the upland in the area marked by the east end of the straightedge was subtracted from the prevailing elevation at the west end, and the horizontal distance (about 150 miles) was measured along the straightedge.

\section{INFLUENCE OF ROCK RESISTANCE}

At some places, the channels of the Loup Rivers may be cut into the Ogallala Formation. Certain lithologic units of the Ogallala, particularly the carbonate-cemented sandstone, are moderately resist- ant to channel erosion. The conspicuous bulge in the long profile of the South Loup (fig. 10) between Cumro and Ravenna is attributed to resistant bedrock although no outcrops were observed in the river channel. Information from drilling and from gravel pumping indicates that the channels of the Loup Rivers generally are underlain not by the Ogallala Formation but rather by several tens of feet of alluvial gravelly sand.

From place to place along all the Loup Rivers, gravel for road building is pumped from beneath the river channel or from low terraces along the river. However, test drilling has shown no commercial deposits of gravel for long distances along the rivers. For example, no gravel has been found along the South Loup between Arnold and Ravenna. Test drilling at gravel-producing localities has shown that the thickness and distribution of gravel are sporadic even within an area of a few acres.

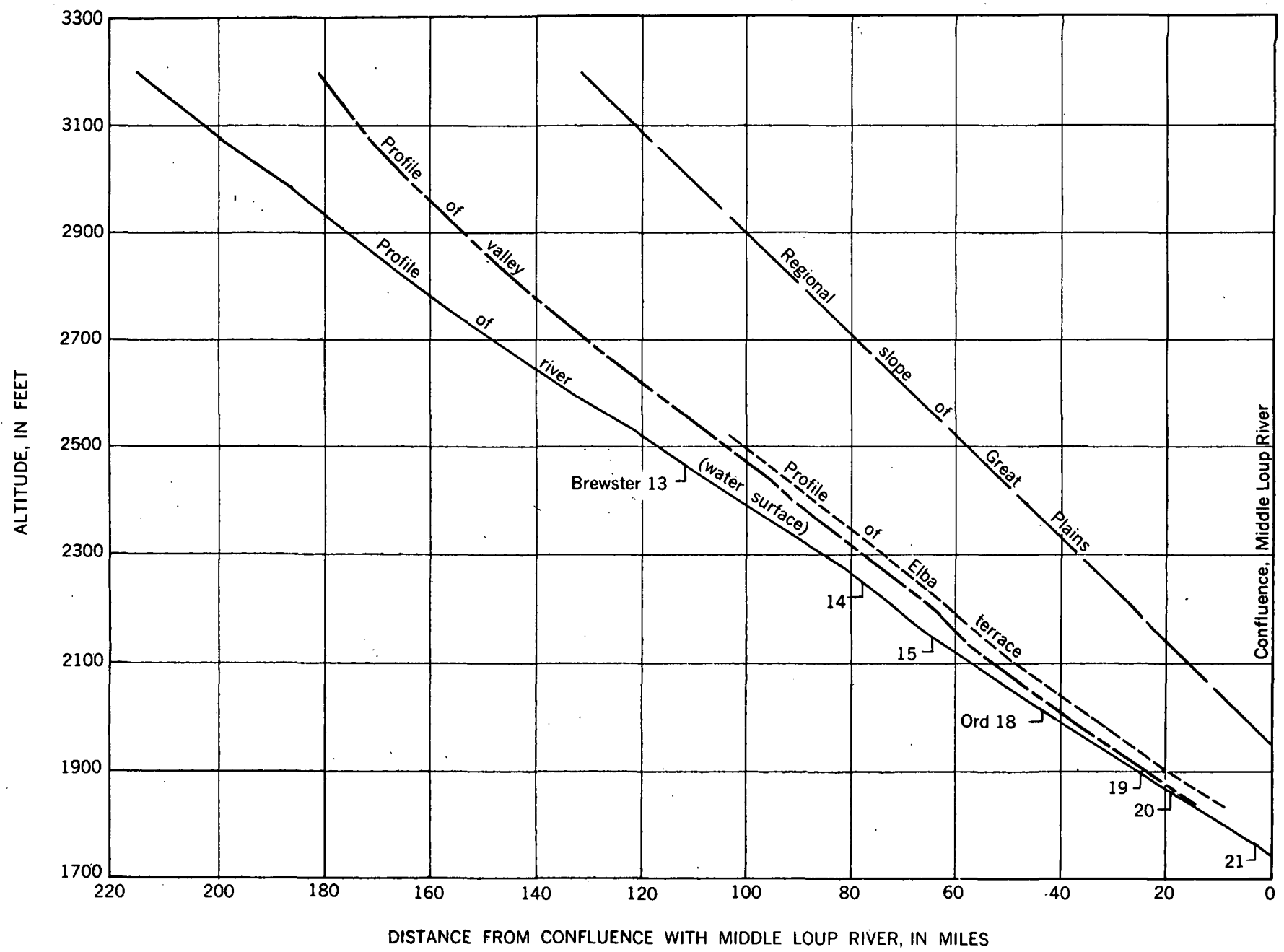

Froure 8.-Longitudinal river profle, valley profle, and Elba terrace profile, North Loup River, Nebr. Reglonal slope of Great Plains ts shown for comparison. Numbers refer to gaging stations in table 2. 
Gravel is pumped from depths as great as 40 feet, and nearly all this gravel is less than 1 inch in diameter. Coarser gravel, which is rejected by the Nebraska Highway Department, is separated by screening. The rejected gravel probably represents less than 2 percent of the total sand and gravel pumped, and it consists mostly of pebbles less than 2 inches in diameter; although cobbles as much as 6 inches in diameter were seen, they represent less than 5 percent of the rejected gravel. Competency of the Middle Loup to transport pebbles as much as 1 inch in diameter is indicated by the occasional observance of such a pebble in the artificial turbulence flume at Dunning.

Gravel deposits do not seem to be concentrated beneath the bed of the river, but rather they seem to be interbedded with sand and silt down to the maximum depths reached by the pumps. Most of the commercial gravel deposits are probably within the valley fill of the Elba terrace. Gravel lenses in the fill of the Elba terrace were probably derived from older gravel deposits exposed upstream. Some commercial deposits are within older valley fills (of Kansan, Illinoian, or Peorian age) that have been recently exposed by lateral migration or by downcutting of the rivers. The sporadic lateral and vertical distributions of the gravel as well as its small size indicate that gravel has not prevented the rivers from adjusting their gradients by incision.

In general, the valley fills of ancestral rivers are easily erodible and permit the development of wide, shallow cross sections. Nearly everywhere the river banks are formed by terraces cut in late Recent time which are underlain by valley fill of the Elba terrace. This fill consists dominantly of sand along the braided North Loup and Middle Loup and of silty sand along the meandering South Loup.

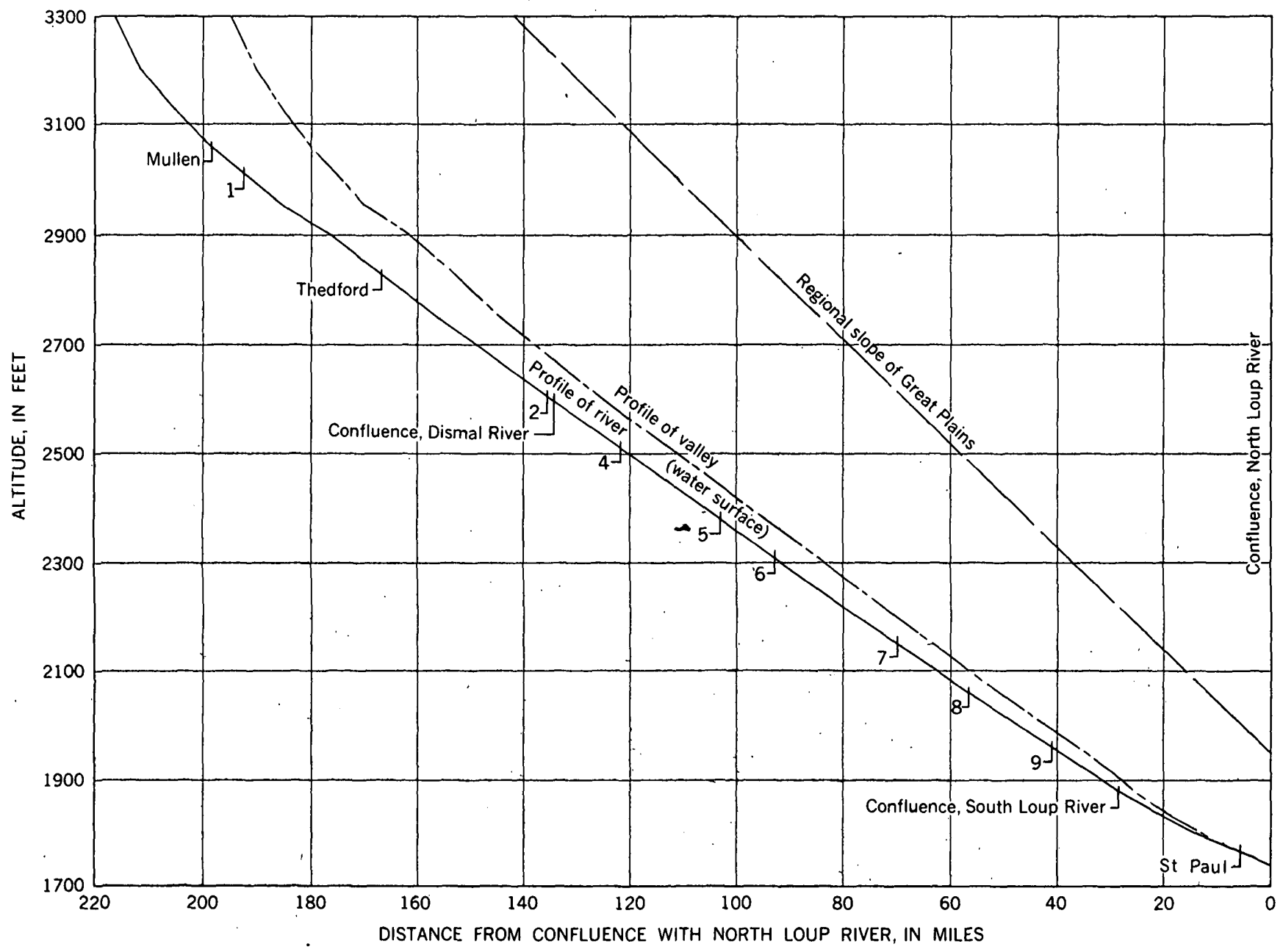

Fioure 9.-Longitudinal river profile and valley profle, Middle Loup River, Nebr. Reglonal slope of Great Plains ts shown for comparl8on. Numbers refer to gaging stations in table 2. 


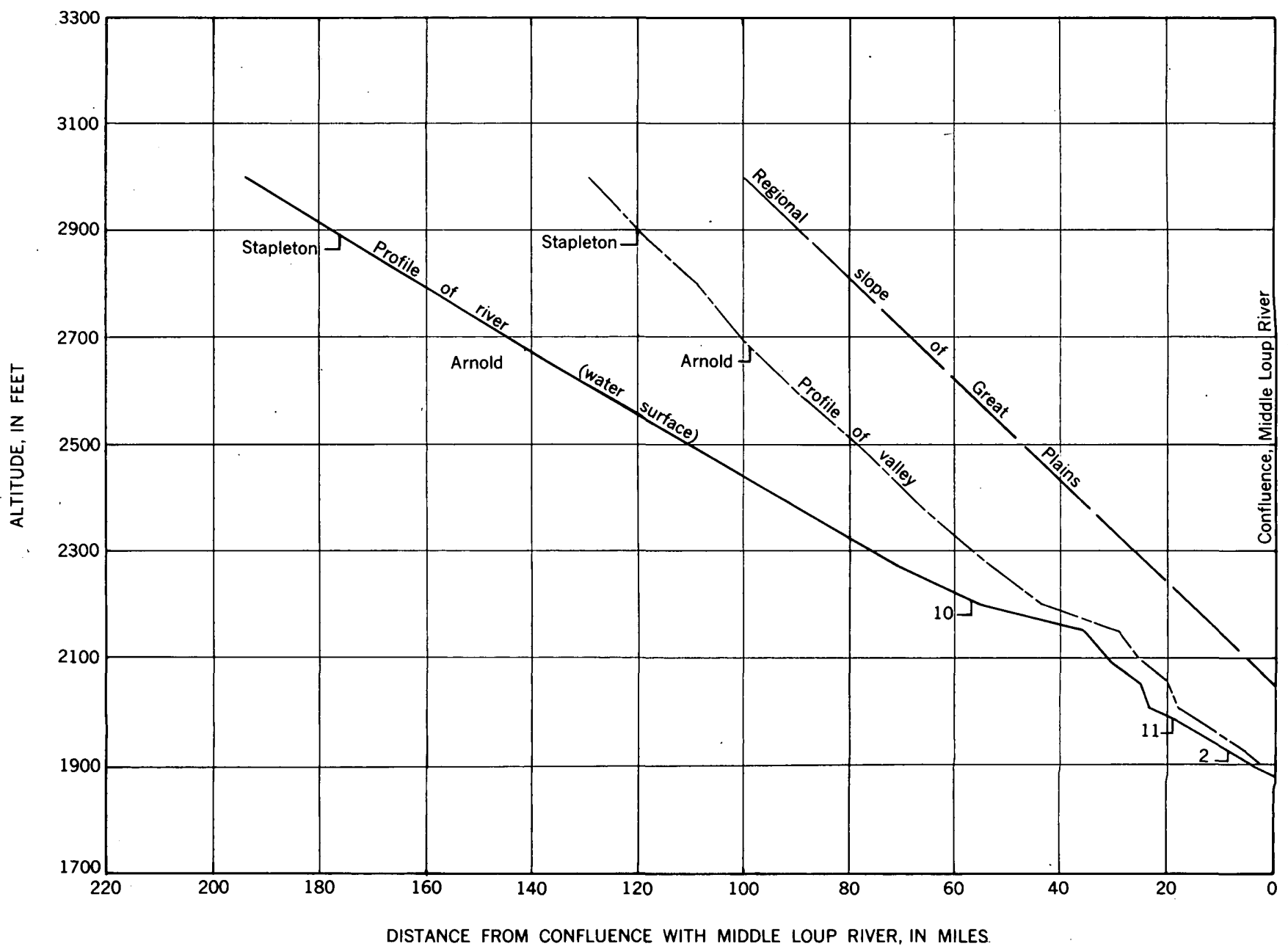

Figure 10.-Longltudinal river profile and valley profile, South Loup River, Nebr. Regional slope of Great Plains is shown for comparison. Numbers refer to gaging stations in table 2.

\section{INFLUENCE OF REGIONAL SLOPE AND RELIEF}

The influence of regional slope and relief on the long profiles of rivers can be shown either by comparing the profiles of rivers in mountainous regions with the profiles of rivers on plains or by noting the profile changes along a single river as it flows across different physiographic provinces. For example, the profile of the Arkansas River in the Rocky Mountains upstream from Canon City, Colo., is steep and irregular; it is nearly straight across the Great Plains, but it flattens across the Interior Lowlands and flattens still more as the river traverses the structural trough of the Arkansas Valley and enters the Gulf Coastal Plain. Miller (1958) investigated the characteristics of streams that flow across resistant rocks in mountainous areas onto unconsolidated deposits of the Rio Grande depression. He concluded that channel slope is " $* * *$ a partially independent variable, determined by inherited conditions that the stream can gradually modify, but only within certain limits."
In accounting for the shape of long river profiles, many writers give insufficient attention to the influence of regional slope. However, Rubey (1952, p. 135) stressed the significance of regional slope in his discussion of the long profiles of the Missouri and Platte Rivers. He noted that the Missouri River, from about 2,000 miles upstream from Great Falls, Mont., to its mouth, flows at an approximately uniform distance below the older uplands that border it. He remarked that " $* * *$ one is forced to believe either that the discharge and load of the present Missouri River are such that they almost exactly fit the slopes of these old upland surfaces $* * *$ or, as seems more likely, that the profile of the present stream has been greatly influenced by the slope of the earlier surfaces on which it began its work." Also, he suggested that the Platte River flows on a preexisting slope on which it has attained equilibrium by development of a very shallow cross section rather than a flatter gradient. 
The direction of the Loup River courses is closely related to the direction of slope of the Great Plains. In this part of Nebraska the surface of the Great Plains dips about S. $75^{\circ}$ E. at about 9.5 feet per mile $(0.0018 \mathrm{ft}$ per $\mathrm{ft})$. The upper courses of both the North Loup and the Middle Loup trend about S. $70^{\circ}$ E.-that is, almost directly down the dip of the Plains. Beyond the Sandhills, the courses of the two rivers remain generally parallel but swing southward to about S. $40^{\circ} \mathrm{E}$. In its upper course the South Loup trends S. $60^{\circ}$ E., but between Cumro and Ravenna it swings northward and trends slightly north of east. The trend of the Calamus River is generally uniform at about S. $55^{\circ} \mathrm{E}$.

The river slopes and the valley slopes of the Loup Rivers are similar although somewhat less steep than the slope of the Great Plains. (See figs. 8, 9, 10). The slopes are less steep owing to the sinuosity of the rivers and their valleys rather than to the incision below the surface of the Great Plains. In fact, the manner of incision of the rivers tends to make their slopes steeper than the slope of the Great Plains because the incision is deeper in the lower courses than in the headwaters. For example, the upper reaches of the North Loup (in the Big Galls quadrangle) are incised to a depth of about 100 feet below the surrounding upland whereas the lower reaches, near the confluence with the South Loup (about 215 river miles downstream), are incised to a depth of about 200 feet below the upland. The long profiles of the Loup Rivers and the profile of the Great Plains are alike in being nearly straight. Although the profile of the North Loup flattens at its lower end and steepens at its upper end, the straightness of most of the profile can be demonstrated by laying a straightedge along it. The profile of the Middle Loup, which is nearly straight from the headwaters to the confluence with the North Loup, has an average slope of about 0.00125 as compared with a slope of 0.0018 for the Great Plains.

One explanation for the similarity between the profiles of the Loup Rivers and the profile of the Great Plains is that all are a result of gradation by eastward-flowing streams of similar hydraulic characteristics. There is, however, no convincing evidence that the eastward slope of the Great Plains is fundamentally a result of stream gradation. Instead, the surface of the Great Plains may have been merely flattened originally by subaerial processes generally, then tilted eastward by tectonic movements related to Cenozoic uplift of the Rocky Mountain region. As shown by geologic sections across Nebraska (Condra and others, 1950 , fig. 8), the fluvial formations of Cenozoic age (Chadron, Brule, and Ogallala Formations)

719-579 O-64-3 were deposited generally parallel to an erosional surface on rocks of Cretaceous age. A similar relation between the Ogallala and this erosional surface is shown on geologic sections by Frye and others (1956, p. 19), who also presented convincing stratigraphic evidence that the Ogallala does not represent a series of coalescent alluvial fans sweeping eastward from the Rocky Mountains. Instead, the Ogallala represents a series of alluvial fills in shallow eastwardtrending valleys cut in rocks of Cretaceous age; the fills overlapped laterally onto the gently sloping valley sides, buried the interstream divides, and eventually formed a coalescent alluvial plain. But the thickness of the Ogallala does not change greatly from west to east, and its total thickness (about $400 \mathrm{ft}$ ) is insufficient to have much effect on the slope of the Great Plains, which are about 400 miles in breadth. The origin of the eastward slope of the erosional surface on rocks of Cretaceous age remains in doubt, but the overlap of the Ogallala across the Chadron and Brule suggests either a differential tectonic downwarping of the Great Plains or a differential upwarping of the source areas to the west (Frye and others, 1956, p. 50). In addition, the initial eastward dip of the Ogallala probably has been increased by tectonic movements in post-Ogallala time.

The profiles of the Loup Rivers have probably been inherited from the Great Plains profile. Many river profiles are characterized by a downstream decrease in slope which generally is attributed to a downstream increase in discharge or to a downstream decrease in particle size of load. Because average discharge remains nearly constant for long distances along the middle courses of the North Loup and Middle Loup, downstream decrease in slope is perhaps not to be expected. Also, there is very little downstream change in particle size of load for any of the Loup Rivers. However, bank-full discharge shows a rather sharp rate of increase downstream along the North Loup and Middle Loup. Both average discharge and bank-full discharge increase downstream along the South Loup, which has a notably straight long profile. Long profiles of the Loup Rivers are not significantly altered by substantial increases in discharge at the confluence of major tributaries. For example, the average discharge of the Middle Loup is increased by a factor of nearly two below the confluence of the Dismal River; yet, this increase in discharge is not accompanied by any significant change in slope. If, as seems apparent for the Loup Rivers, slope is not changed in response to variations in discharge or channel pattern, then the rivers would have little tendency to modify an inherited slope. Hydraulic adjustment to changes 
in discharge and channel pattern is made mostly by change in cross section.

\section{THE MIDDLE LOUP RIVER AT DUNNING HYDRAULIC FACTORS IN RELATION TO WIDTH}

In their report on sediment transportation, Hubbell and Matejka (1959) presented detailed tables of basic hydraulic data on different sections of the Middle Loup River at Dunning, Nebr. The location of sections discussed herein is as shown in figure 11. Sections $\mathbf{A}$ and $\mathbf{E}$ mark the limits of a reach about 7,900 feet in length. Section A has a bank-full width of about 340 feet, and the channel contains emergent bars during ordinary stages. The bank-full width of section $\mathrm{C}_{2}$ is about 85 feet, and that of section $\mathrm{E}$ is about 150 feet. Section $\mathrm{C}_{2}$ is free of emergent sandbars, but at section $\mathrm{E}$ emergent bars may form near the center of the channel at low flows. The flow at section B is confined by bridge abutments to a width of about 65 feet, but the flow at other sections is not artificially confined, except perhaps by vegetation and by some brush riprap at section $\mathrm{C}_{2}$. Cross profiles of sections $\mathrm{A}, \mathrm{C}_{2}$, and $\mathrm{E}$, measured at a discharge about equal to average discharge, are shown in figure 12. The data for each of these sections permit an analysis of the hydraulic adjustments made by the river at constant discharge as it flows through sections of distinctly different widths.

The relative variation in river width along the reach at Dunning is typical of the variation along many reaches of the North Loup and Middle Loup. The bed and bank materials are nearly uniform along the reach at Dunning; therefore, variations in width cannot reasonably be assigned to variations in particle size of bank materials. Variations in width might be assigned to variations in vegetal growth on the banks; yet, the present vegetation at section $\mathbf{A}$ is similar to that at section E. At both sections, the left bank has a dense growth of willows and other trees whereas the right bank is sodded. Variations in width are perhaps related to past conditions of vegetal growth on the banks. Photographs of the sections are reproduced by Hubbell and Matejka (1959).

Basic data for each section include measurements of discharge $(Q)$, effective width $\left(W_{e}\right)$, effective area $\left(A_{c}\right)$, mean suspended-sediment concentration, local slope, reach slope, and water temperature. Mean velocity was calculated from $Q / A_{e}$ and mean depth

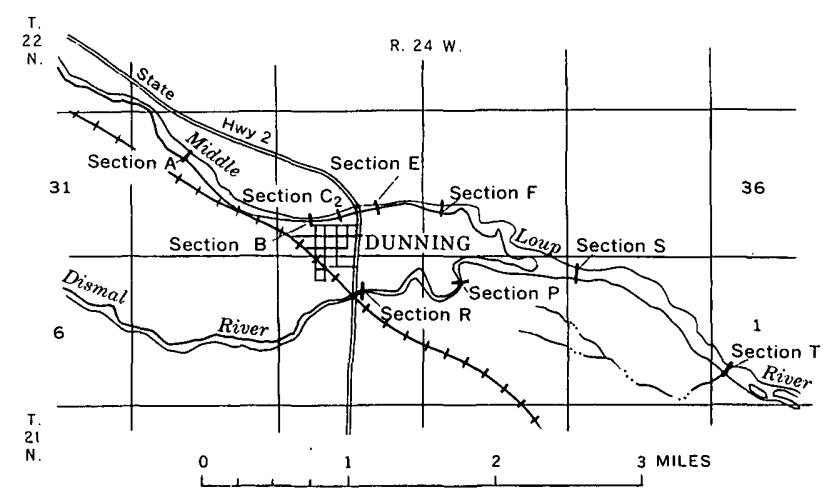

Figure 11.-Location of sections on a reach of the Middle Loup and Dismal Rivers near Dunning, Nebr.

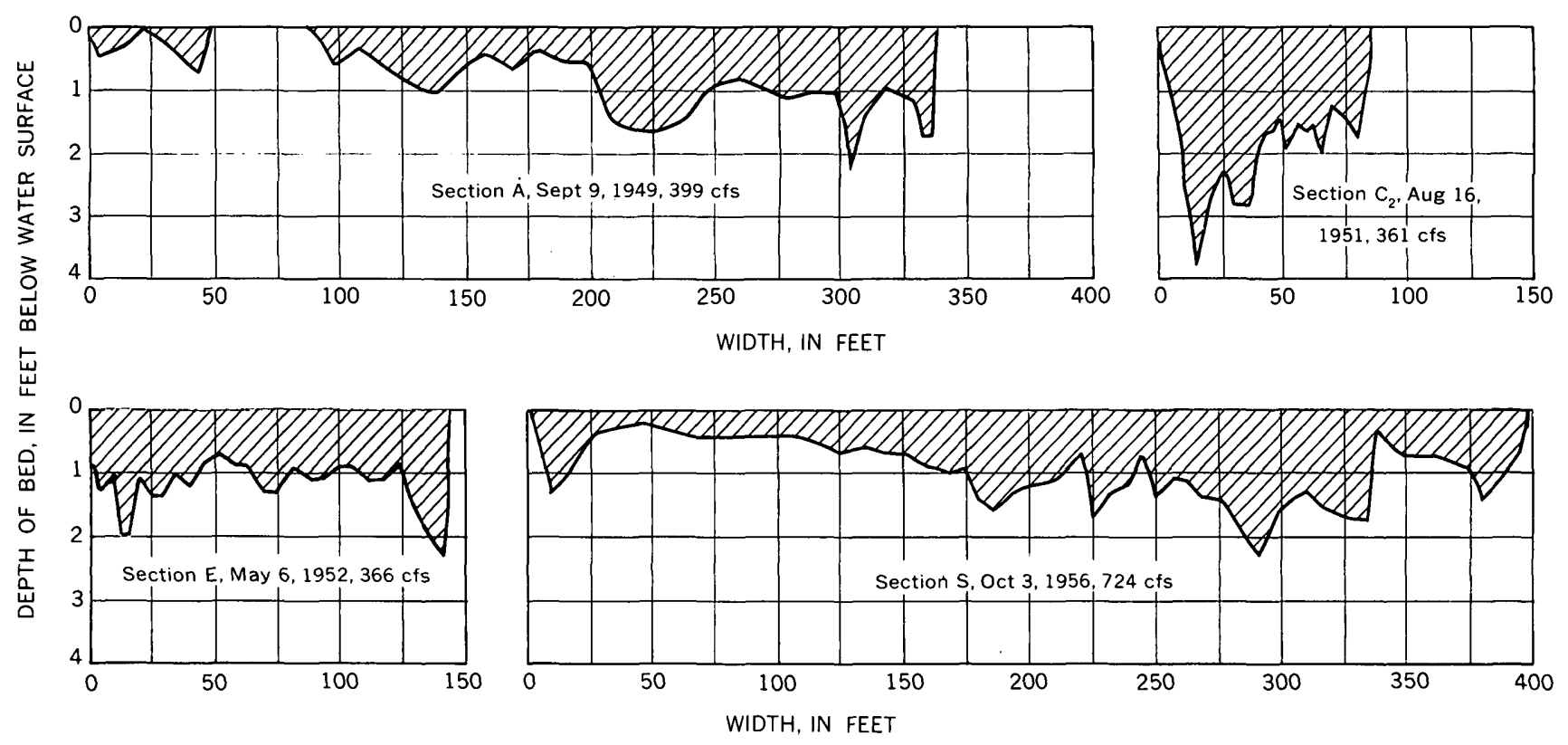

Froure 12.-Cross profiles of Middle Loup River at Dunning, Nebr. Section $A, C_{2}$, and E after Hubbell and Matejka (1959) ; section $S$ after Hubbell (1960). 
from $A_{\theta} / W_{\theta}$. Effective width is defined as the length of a discontinuous line that crosses the channel and that is normal to the direction of flow at every point on the line. Width of sandbars is not included in effective width. Effective area is the sum of the products of effective width and measured depth for each section of a water-discharge measurement. Local slopes were measured with staff gages placed 300 feet upstream and 300 feet downstream from a section. At section $\mathrm{A}$, the slope determined from the readings of these gages is questionable because the slope differed from one individual channel to another and also because transverse flow at the section caused local differences in slope along each bank. The reach slope is based on the difference in water-surface elevation between sections $\mathrm{A}$ and $\mathrm{E}$. For each of the hydraulic properties listed above, except slope, 33 measurements were available for section $\mathrm{A}, 37$ for section $\mathrm{B}, 23$ for section $\mathrm{C}_{2}$, and 49 for section $\mathrm{E}$. Of local slope, 20 measurements were available for section $A, 11$ for section $\mathrm{C}_{2}, 31$ for section $\mathrm{E}$, and none for section $\mathrm{B}$. Some water temperatures were estimated by the writer on the basis of past records of water temperatures for that calendar date, and others were extrapolated from temperature measurements made at another section on the same date.

In figure 13 , mean value of mean depth, mean velocity, local slope, and effective area are plotted, on rectangular-coordinate paper, against effective width at sections $\mathrm{B}, \mathrm{C}_{2}, \mathrm{E}$, and $\mathrm{A}$. The mean values were obtained from measurements grouped according to discharge.

Mean velocity and mean depth decrease as effective width increases whereas effective area and slope increase as effective width increases. Unfortunately, the scope of the data is insufficient to define adequately the form of the equations that would relate effective width to the other variables. Moreover, the effective widths at section $\mathbf{A}$ are not strictly comparable with the effective widths at the other sections because bars, submersed to shallow depth, are commonly present at section $\mathbf{A}$ but are rarely present at the other sections. A bar submersed to a depth of 6 inches, for example, would not influence the effective width at section $\mathbf{A}$, but it would influence the hydraulic characteristics of the channel. A measure of width at section A that is about comparable with the effective width at the other sections is the water width at half mean depth. The mean value of the water width at half mean depth at section $\mathrm{A}$, for discharges of 350 399 and $400-449 \mathrm{cfs}$, is about 215 feet. The points representing these discharges at section $\mathbf{A}$ should probably be moved to the left to an effective width of about 215 feet. At the other sections, the effective width as plotted is about equal to the water width at half mean depth.

The increase in effective area with increasing width at constant discharge has been noted for many other sandbed streams (B. R. Colby, oral communication, 1961). An explanation of this increase must take into account the necessity for continuity in both bed-material discharge and water discharge from section to section, regardless of the width of the section. If only water discharge were involved, many different combinations of hydraulic adjustments might be possible; for example, the cross-sectional area might remain constant, and slope might increase enough to increase average velocity (in spite of decreasing depth). Continuity of bed-material discharge, however, requires a decrease in bed-material discharge per foot of stream width as the stream widens; if the width of the stream is doubled, the discharge of bed material per foot of width must be decreased by half. The decrease in bed-material discharge per foot of width requires a decrease in velocity and an increase in effective area.

The reach slope remains constant at about 0.0013 foot per foot for the whole range of discharges and widths shown in figure 13. This reach slope corresponds to the local slope expected for a discharge of $450-500 \mathrm{cfs}$ at a width of about 225 feet, which is the average width of the reach. Average width of the reach was determined by dividing the surface area of the reach by its length. Average discharge at Dunning is about $385 \mathrm{cfs}$ and bank-full discharge is about $570 \mathrm{cfs}$. The reach slope may therefore be adjusted to a discharge between average discharge and bank-full discharge.

Data were grouped and graphs were prepared to investigate the relation of local slope to discharge and suspended-sediment concentration at sections $\mathbf{A}$ and E. For the range of measurements available, local slope showed no definite relation either to discharge or to suspended-sediment concentration.

\section{HYDRAULIC FACTORS IN RELATION TO BRAIDING}

For a shallow stream of uniform depth that is flowing at bank-to-bank width, the growth of bars or islands in the channel not only divides the flow into braids but also reduces the water width to a value less than bank-to-bank width. The reduction in water width is a measure of the degree of braiding. Section A has well-defined banks, and its bank-to-bank width remained at about 340 feet during the period of measurement (1949-56). The section is in a nearly straight reach of the river; therefore, no tendency for the thalweg to remain near one bank would be expected. At 

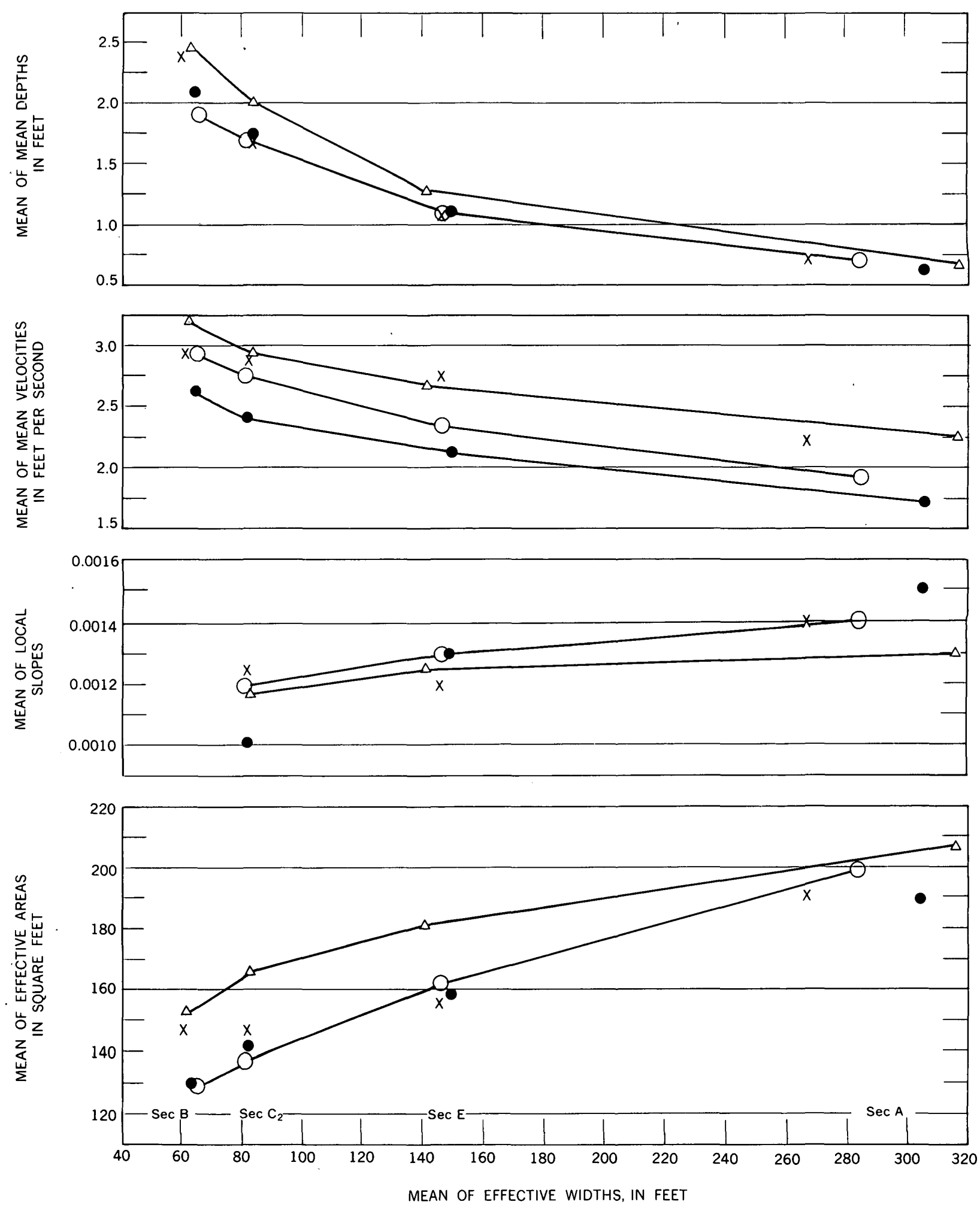

Discharge groups

- 300-349 cfs X 400-449 cfs

350-399 cfs $\triangle 450-500 \mathrm{cfs}$

Figure 13.-Mean depth, mean velocity, local slope, and effective area in relation to effective width at sections $B$, $C_{2}$, E, and A, Middle Loup River at Dunning. 
discharges of $350-500 \mathrm{cfs}$, the width of flowing water would extend from bank to bank if no bars were present, and the effective width would approximate the bank-to-bank width.

To investigate the changes in channel configuration from time to time at section $\mathrm{A}, 30$ cross profiles were plotted (from notes of water-discharge measurements made during the period 1949-56) on a horizontal scale of 40 feet to the inch and a vertical scale of 2 feet to the inch. Seven of these profiles, mostly pertaining to water discharge measurements of $400-449 \mathrm{cfs}$, are shown in figure 14. The position of greatest depth in the cross profile shifts apparently at random through the width of the stream, although there is some tendency for the deeper channels to be near the banks rather than midway between the banks. Cross profiles of the channel on successive days (such as on Aug. 30 and 31,1949 ) show no major changes in configuration, but in a period of 2 weeks the configuration can change completely. For example, compare the cross profile of April 12, 1950, with that of April 25.

The effect of a bar submersed to a depth of a few tenths of a foot is not very different from the effect of an emersed bar on the flow of water through a given cross section. The water velocity in the shallow depth above the submersed bar is low, and the crosssectional area of the stream above shallowly submersed bars is only a small part of the total cross-sectional area. Shallowly submersed bars do not confine the flowing water at the surface of the stream, and their width enters into the measurement of effective stream width only if the water above the bar is nearly motionless.

To evaluate the effect of all bars and islands on such hydraulic variables as effective area and mean velocity, some means of expressing numerically the configuration of the channel cross profile is needed. Many schemes were tried in an effort to derive a single number that would take into account all the irregularities of the cross profile, but none led to a number that was unique for a particular configuration. However, a measure of water width was devised to take into account the effect of bars submersed to shallow depth. This measure is called the water width at half mean depth. It was measured by laying a straightedge across the plotted cross profile at a distance from the water surface equal to half mean depth; the width of bars that intersected the straightedge were excluded, and the increments of water width at this depth were summed.

The choice of half mean depth as a suitable depth at which to measure water width was made by trialand-error measurement on the 30 plotted cross pro- files at section A. Absolute depth was not chosen because such a choice might lead to the statement of a water width of zero for a very shallow cross section. Of the different fractions of mean depth that were tried, half mean depth seemed most appropriate. Inspection of the velocities and cross-sectional area above bars submersed to a depth equal to or less than half mean depth indicated that only a small part of the water discharge is transmitted above such bars, whereas a significant part of the discharge is transmitted above bars submersed to greater depths. Even where bars submersed to a depth equal to or less than half mean depth occupy much of the width of the cross section, only a small percentage of the total discharge is transmitted above these bars. For example, only about 11 percent of the total discharge was being transmitted above the shallowly submersed bars on the cross section dated Sept. 13, 1949 (fig. 14). The.water width at half mean depth is only 54 percent of the effective width measured at the water surface For the 30 cross profiles that were plotted, the mean value of half mean depth is 0.36 foot, the standard deviation is 0.04 foot, and the range is 0.28 to 0.47 foot.

The graphs of figure 15 show effective area, local slope, mean velocity, and maximum depth at section A in relation to the water width at half mean depth. (See table 1.) In addition, points representing mean values of effective area and mean velocity at sections $\mathrm{B}, \mathrm{C}_{2}$, and $\mathrm{E}$ (and mean values of local slope at sections $\mathrm{C}_{2}$ and $\mathrm{E}$ ) are shown for comparison. Maximum depth is not the absolute maximum depth, which is too fortuitous to be significant, but it is the maximum depth above which lies 95 percent of the effective area. It was measured by laying a straightedge across the bottom of the plotted profile, sliding the straightedge upward until it reached the level below which lay 5 percent of the effective area, and then taking the water depth at that level. Mean velocity is computed from discharge divided by effective area. Local slope, which is not available for all the plotted points, is from Hubbell and Matejka (1959, p. 82). Effective area is from the same source and from the original notation of water-discharge measurements.

Curves were fitted to the points applying to section A by the method of least squares; correlation coefficients and fitted curves are shown on the graphs. A linear relation is assumed because the range of data is insufficient to warrant the investigation of more complex relations. The correlation coefficients indicate a significant positive correlation with effective area at the 1-percent level and indicate a significant negative correlation with maximum depth and mean velocity, also at the 1-percent level. No significant 

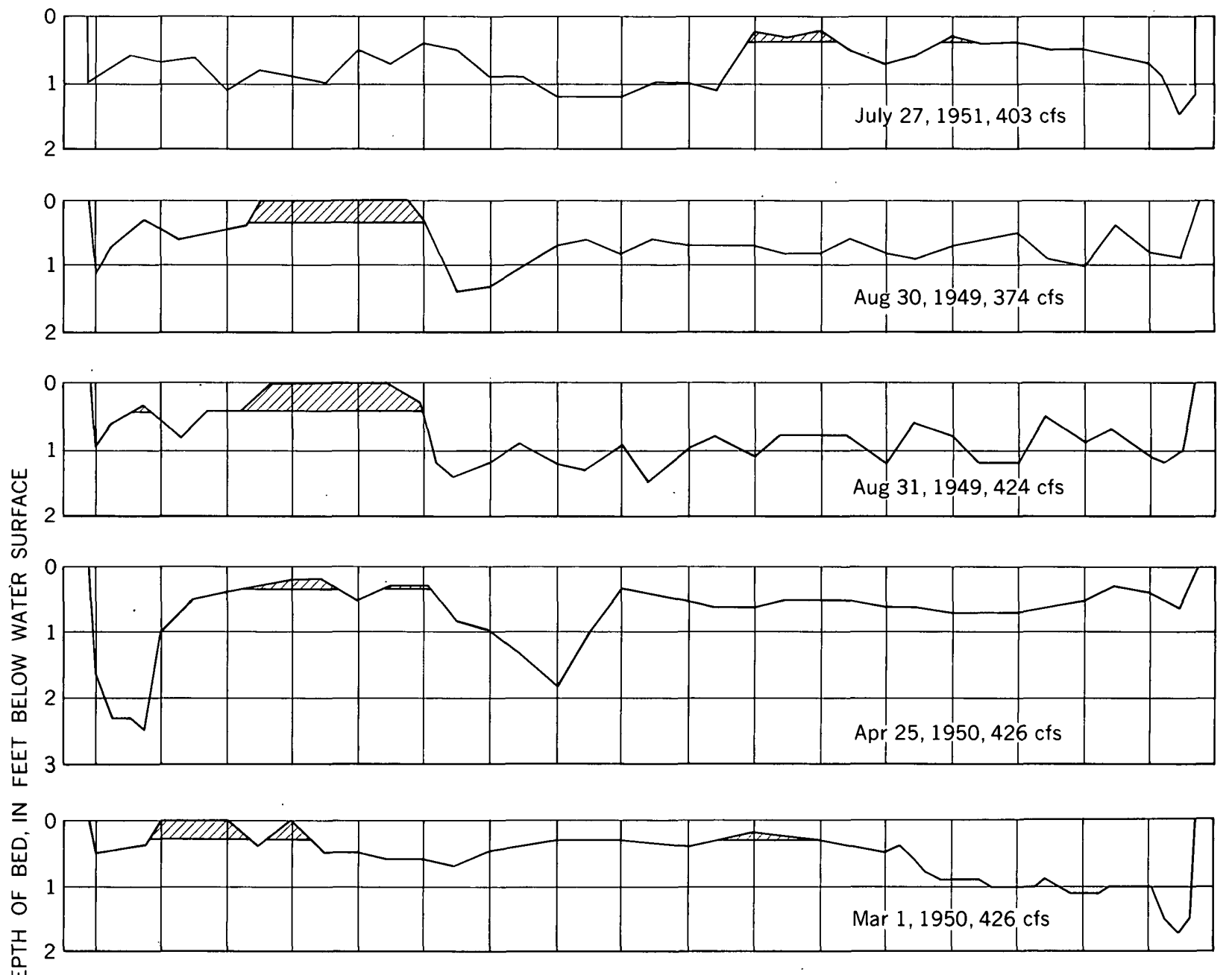
岁
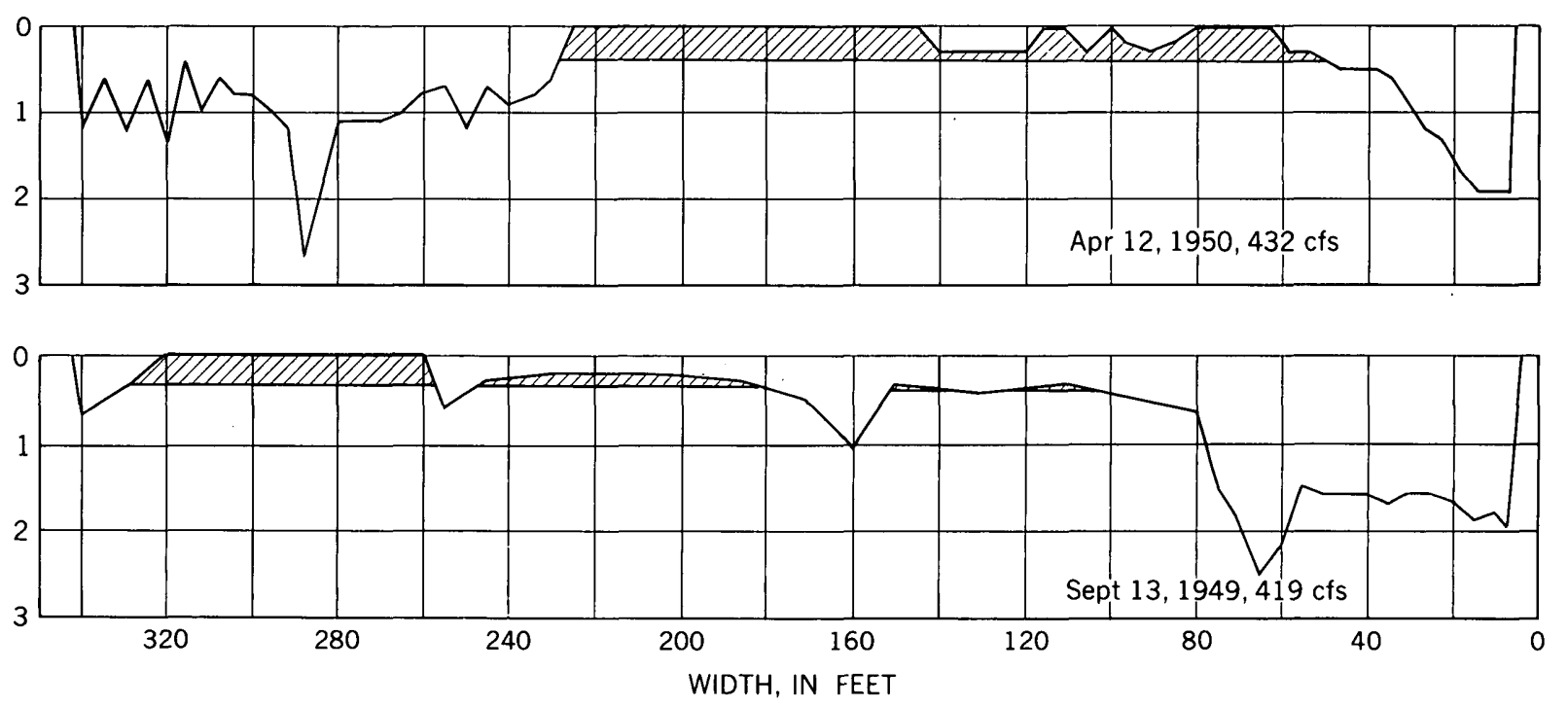

Figure 14.-Cross profiles of section A, Middle Loup River at Dunning. Bar widths that are above half mean water depth are indicated by shading. 
PHYSIOGRAPHIC AND HYDRAULIC STUDIES OF RIVERS
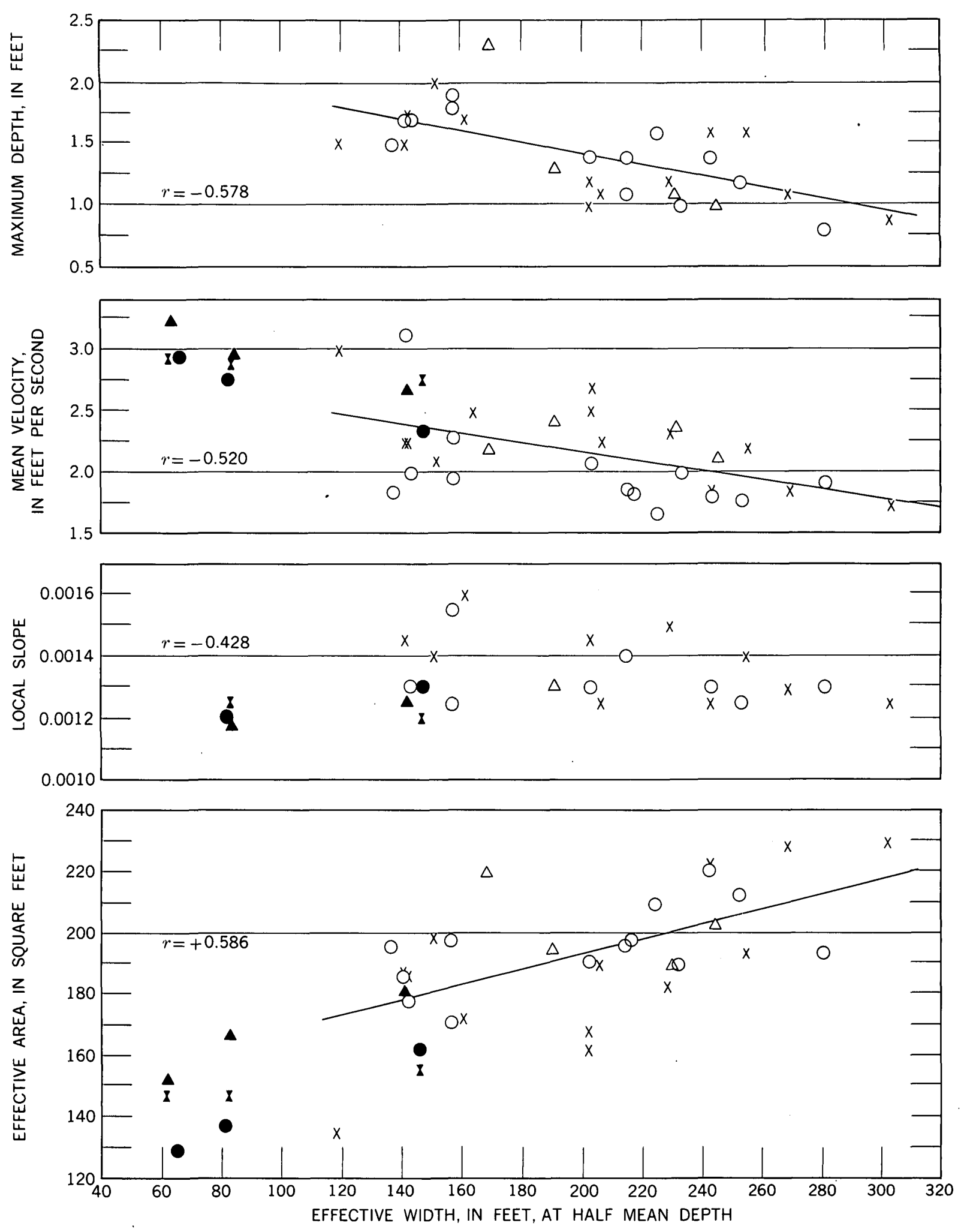

Discharge groups

- $0350-399 \mathrm{cfs} \quad$ × X 400-449 cfs

$\Delta \triangle 450-500 \mathrm{cfs}$

Figurb 15.-Maximum depth, mean velocity, local slope, and effective area in relation to water width at half mean depth, section A, Middle Loup River at Dunning. Mean values for sections $B, C_{2}$, and $E$ as plotted in figure 13 are shown (darker points) for comparison. 
correlation with local slope is indicated at the 5-percent level; therefore, the curve is not shown.

Unlike the points representing mean values at sections $\mathrm{B}, \mathrm{C}_{2}$, and $\mathrm{E}$, the points representing individual measurements at section $\mathrm{A}$ show no alinement according to discharge. This is attributed in part to the fact that significant differences in channel configuration apply to points in the same discharge range; water width at half mean depth is an imperfect measure of channel configuration. In addition, much of the scatter of points is related to differences in water temperature. For example, of the 12 points that lie above the velocity curve, 10 represent measurements made at a water temperature of less than $50^{\circ} \mathrm{F}$, whereas only
2 represent measurements made at a water temperature of more than $50^{\circ} \mathrm{F}$. Of the 14 points below the velocity curve, only 2 represent measurements made at a water temperature of less than $50^{\circ} \mathrm{F}$, and the others represent measurements made at a temperature of more than $50^{\circ} \mathrm{F}$. The mechanism by which water temperature affects velocity in the Loup Rivers is complex in that it involves not only a change in water viscosity but also accompanying changes in suspended-sediment concentration and bed form.

The relations shown in figure 15 indicate that the forming of emersed and shallowly submersed bars in a wide, shallow channel renders the channel hydraulically similar, at least in effective area and mean

TABLE 1.-Values of hydraulic factors at section A, Middle Loup River at Dunning, Nebr.

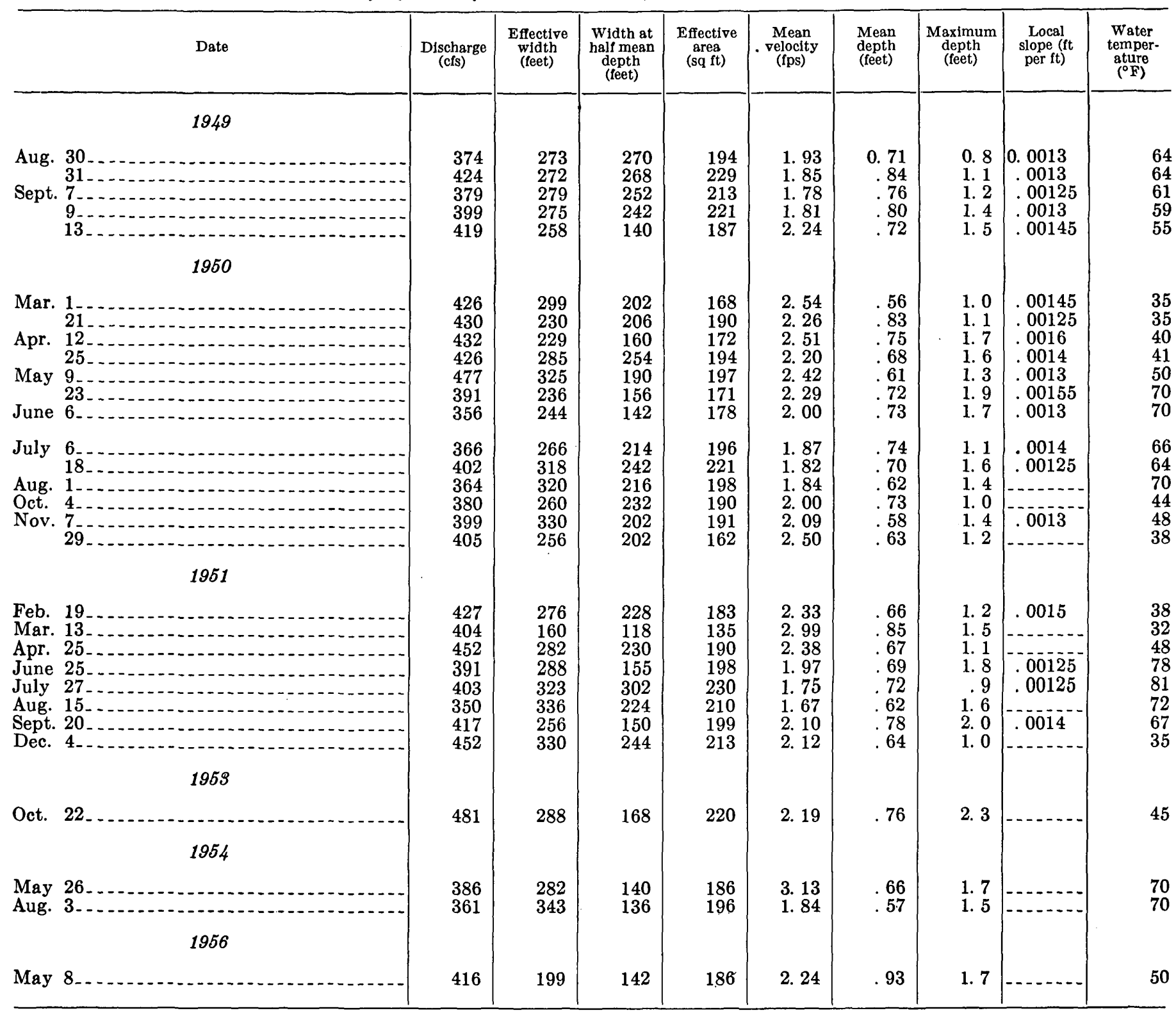


velocity, to a more narrow channel. Also, the greater the width of bars in the channel, the greater is its maximum depth. Because the width of section $\mathbf{A}$ is very great relative to its depth; the effect of banks is insignificant, and two or three channels transmit a given water discharge at approximately the same effective area and mean velocity as a single channel of the same total width.

Although the growth of emersed bars in a channel necessarily causes braiding, a decrease in water width results only if the bank-to-bank width remains constant. If the growth of bars or islands is accompanied by bank erosion, the water width may remain constant or even increase. Also, a reduction in water width can take place without braiding if a single channel is formed. Braiding cannot be equated with a reduction in water width unless a constant bank-to-bank width and the presence of emersed bars or islands are stipulated. The bank-to-bank width at section A, during the period of measurement, passibly remained constant only because the bars were transient.

\section{HYDRAULIC FACTORS IN RELATION TO A CONFLUENCE}

The confluence of the Middle Loup and Dismal Rivers is hydraulically and morphologically similar to the joining of two channels of a braided stream that have been separated by a stabilized alluvial island. In discharge, slope, suspended-sediment concentration, and particle size of load, the Dismal River is similar to the Middle Loup River upstream from the confluence. Therefore, hydraulic adjustments made at the confluence are pertinent to a consideration of adjustments made in a braided stream where channels join or divide.

Measurements made on the same day and at about the same discharge have been given by Hubbell (1960) for six sections on the Middle Loup and Dismal Rivers (see fig. 11); the measurements of water temperature, water discharge, effective area, effective width, and local slope are for all six sections and for 7 different days during 1956. Local slope was measured for a reach 300 feet upstream and 300 feet downstream from each section. In addition, Hubbell reported similar measurements made on 4 days at four additional sections (here designated $\mathrm{S}_{1}, \mathrm{~S}_{2}, \mathrm{~T}_{1}$, and $\mathrm{T}_{2}$ ), which are 300 feet upstream and 300 feet downstream from sections $\mathrm{S}$ and $\mathrm{T}$, respectively. The cross profiles of sections $\mathrm{E}$ and $\mathrm{S}$ are shown in figure 12.

Figure 16 shows the relation of effective area and local slope to effective width for sections upstream and downstream from the confluence. Measurements of effective width and area at each section have been placed into two groups according to discharge and water temperature, and the means of the values within each group are plotted. The upstream sections have been paired and summed as $E$ plus $R$ and $F$ plus $P$, so that the combined discharge of each pair approximately equals the discharge downstream from the confluence. Hubbell (1960, p. 29) used dimensionanalysis and multiple-regression techniques to demonstrate the relations of hydraulic variables at individual sections upstream and downstream from the confluence. The purpose of figure 16 is to show graphically the relations that are considered to be of greatest geomorphic significance. Points in the same discharge group show a linear distribution when plotted on double log paper, and the variables are probably related by a power function. (A power function is also suggested by the distribution of points in fig. 13.) The curves are visually approximated rather than statistically constructed because the scatter of points is small and because no particular significance is attached to the slope value of the curve.

In general, the sum of the widths of the Middle Loup and the Dismal upstream from the confluence is less than the width of the Middle Loup downstream from the confluence. Also, the sum of effective areas for two sections upstream from the confluence is less than the effective area downstream from the confluence. Increase in width at the confluence is probably related to a fortuitous change in bank erodibility, inasmuch as vegetal growth along the banks is generally dense except along the left bank downstream from the confluence (Hubbell, 1960, p. 42). Despite some scatter of points, figure 16 indicates a regular increase in effective area with increase in effective width, regardless of whether effective width applies to the sum of two channel widths or to the width of a single channel. A similar increase in effective area with increasing width has been shown for a single channel (fig. 13).

\section{SUMMARY OF HYDRAULIC FACTORS IN RELATION TO CHANNEL PATTERN}

Among the major aspects of channel pattern are the total width of flowing water and the manner in which this width is distributed in the cross section-whether in a single channel or (as in the braided pattern) in multiple channels. The Middle Loup River at Dunning afforded a good opportunity for investigation of the relation of width, at constant discharge, to other hydraulic variables. The river flows through sections of greatly differing width along a short reach that has no significant downstream increase in discharge. Also, there was available a large number of measurements 
at sections having greatly different widths and a narrow range of discharges. In effect, the variable of discharge was held constant, so that the relation of width to effective area, mean velocity, mean slope, and mean depth could be distinguished. Hydraulic changes that occur when water flows from a wide section to more narrow sections were then compared with hydraulic changes that occur when channel width decreases, owing to braiding, at section A. Also avail- able were detailed measurements of width and other hydraulic variables upstream and downstream from the confluence of the Middle Loup and Dismal Rivers near Dunning. The confluence of these two rivers is considered analogous to the confluence of two channels in a braided stream; therefore, sections upstream and sections downstream from the confluence were compared as to the relation of total width to hydraulic variables.
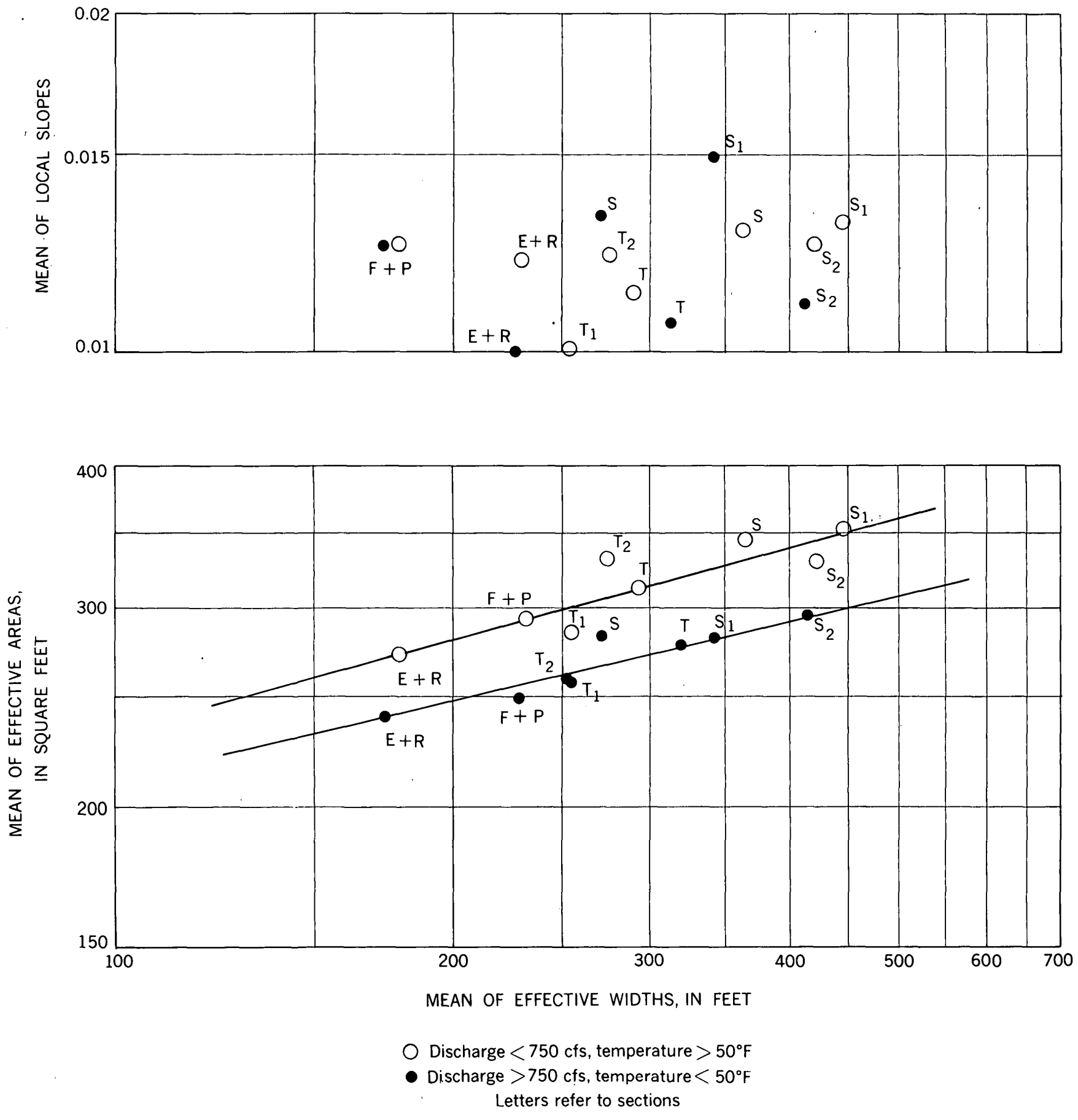

Figure 16.-Effective area and local slope in relation to effective width for sections upstream and downstream from confluence of Middle Loup and Dismal Rivers. 
The conclusions drawn from these investigations are that the effect of braiding at section $\mathrm{A}$ is to decrease the width of flowing water and that the changes in effective area and mean velocity accompanying braiding are similar to the changes accompanying flow from a wide single channel to a narrower single channel. In other words, the effect of braiding on a wide channel is to render it hydraulically similar, at least in effective area and mean velocity, to a narrower single channel. Similarly, if effective width downstream from a confluence is greater than the sum of effective widths upstream from the confluence, effective area is increased and mean velocity is decreased. No definite relation between width and local slope was discerned, partly because the range of data for local slope was less than that for the other variables. Local slope perhaps increases as width increases from section to section; however, no significant correlation was discerned between local slope and braiding at section $\mathrm{A}$ or between local slope and width upstream and downstream from the confluence of the Middle Loup and Dismal Rivers.

\section{OBSERVATIONS ON THE FORMATION OF SANDBARS,} ISLANDS, AND VALLEY FLATS

In laboratory experiments by Leopold and Wolman (1957), braiding began with the deposition of an initial central bar which consisted of coarse particles that could not be transported under local conditions. In natural streams, such a bar may become vegetated and grow into an island, which divides the flow of the stream so that the channel pattern is braided. Bars and islands of the Loup Rivers are built of fine- and medium-grained sand, which is the ordinary bed material of the rivers; their origin cannot be explained as the selective deposition of coarser particles.

As seen on aerial photographs, most submersed bars in the Loup Rivers are either lobe shaped or wedge shaped, and the point of the lobe or wedge is generally oriented downstream. (See fig. 17). A typical bar is about 300 feet long and about 200 feet wide at its widest part. Small lobe-shaped dunes having heights as much as 6 inches and lengths as much as several feet were seen in shallow water on the surface of bars (fig. 18) and elsewhere.
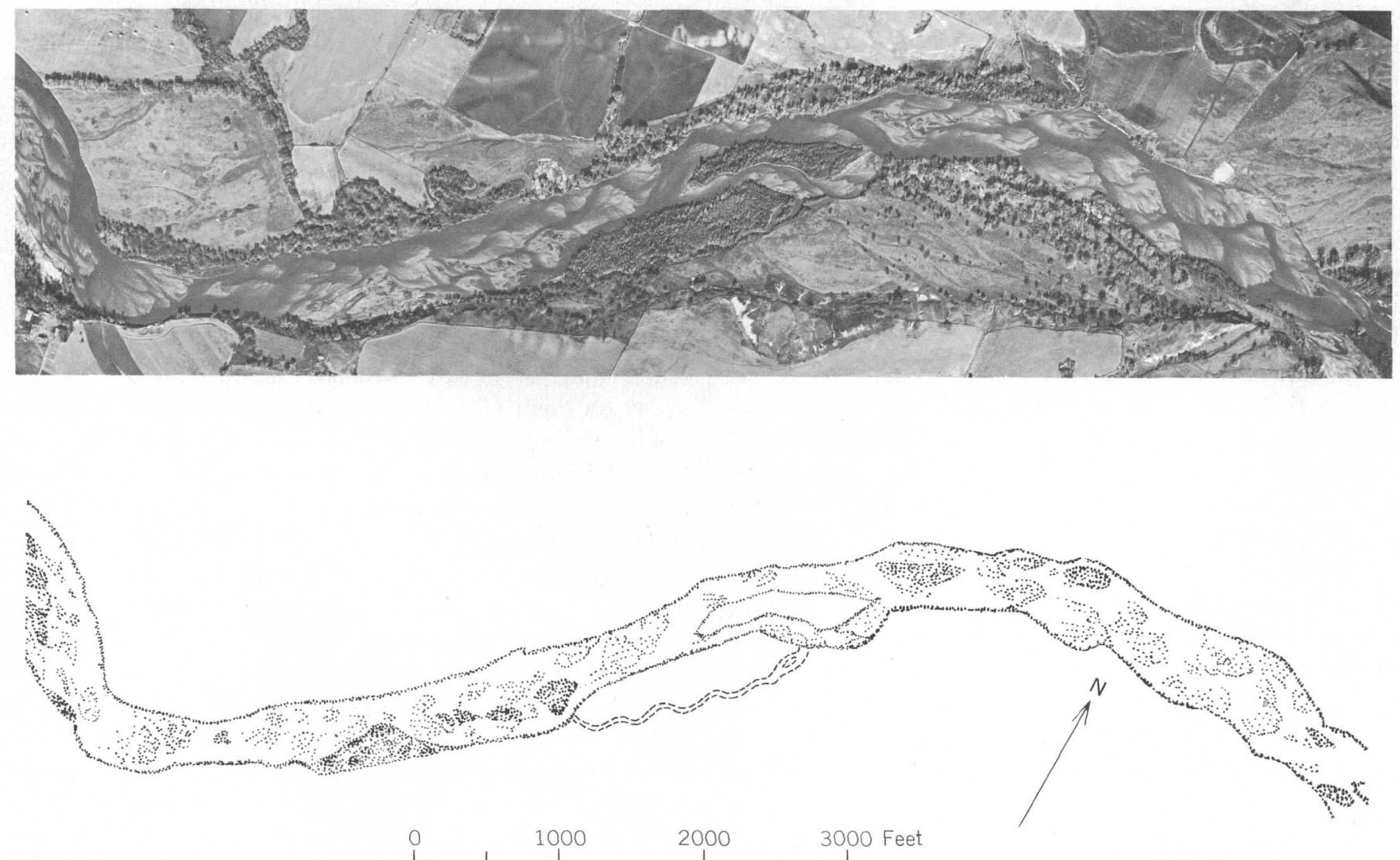

Figure 17.-Aerial photograph and tracing of photograph, North Loup River, about 1 mile downstream from gaging station near St. Paul. On tracing, submersed bars are shown in lightly stippled pattern emersed bars in heavily stippled pattern, and islands are blank. River flows toward right. 


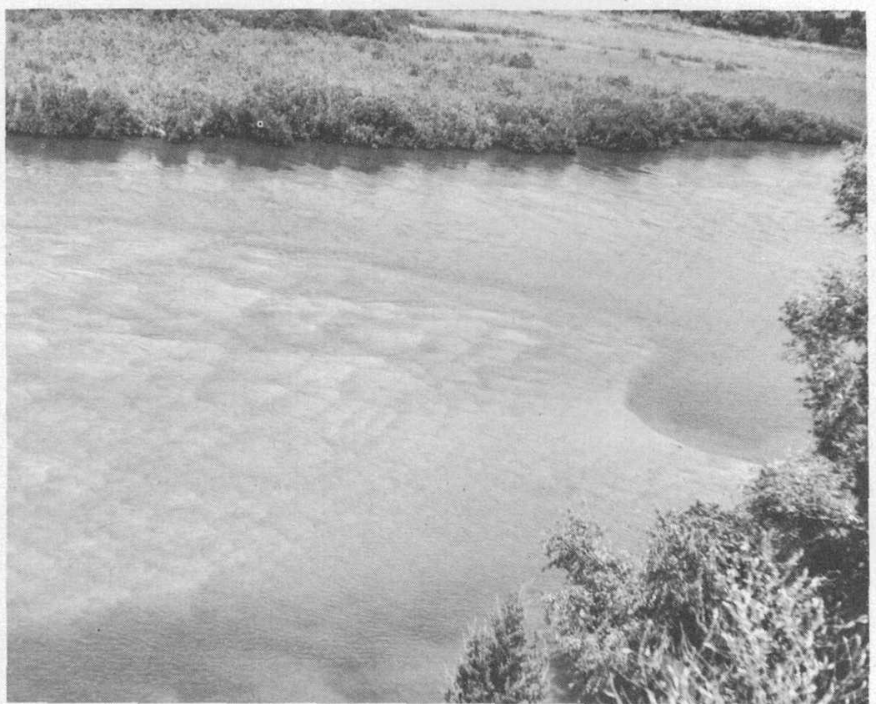

FrgURE 18.-Small lobe-shaped dunes on submersed sandbar in North Loup River 8 miles downstream from Brewster. River flows toward right. Sandbar is being rapidly eroded as salient at lower right migrates upstream.

The large bars and the small dunes probably acquired their similar shapes in the same general way. The forming of small dunes was observed in shallow water at the river edge. First, nearly straight dune ridges several feet long and oriented transversely to the current were formed. The ridges advanced downcurrent and grew rather uniformly in height until the current broke through them in several places, forming scallops from which lobes of sand were built ahead of the original dune ridge. Some lobes increased in height as they were built forward. Increase in height was augmented if a lobe advanced up the backslope of another lobe ahead.

The bar of figure 18 is in a straight, narrow reach of the North Loup River; the reach is shown in the background of figure 19. The bar is not typical of those previously described, but it was studied because the high adjoining bank (Elba terrace surface) afforded a vantage point not found at many places along the Loup Rivers. The channels on either side of the bar are kept clear of sand deposits by high water velocity and by sand boils, which are nearly vertical clockwisemoving eddies that rise from the stream bottom and carry sand in suspension. Erosion of the downstream end of the bar was observed to take place along a deep salient, shown in figure 18 , that moved rapidly upstream.

Many Loup River bars probably originate from sand ridges built across the river bed at right angles to the

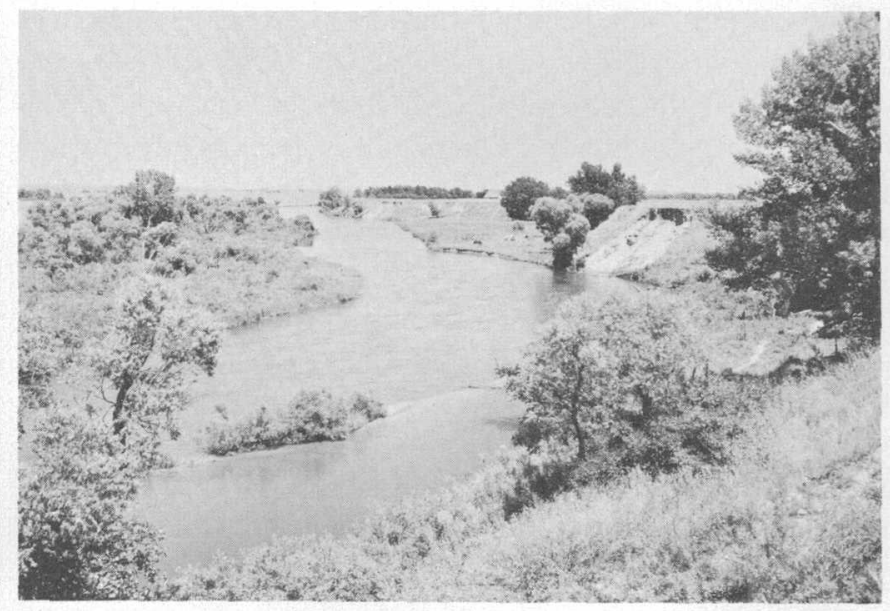

FIgURE 19.- Straight reach of North Loup River, same locality as figure 18. Elba terrace, at right, stands 34 feet above river. Note small willow-covered island in foreground.

prevailing current. Channels are formed where the current breaks through the ridges, and lobe-shaped bars are built in front of these channels. If a lobeshaped bar increases sufficiently in height, the current is diverted around it and forms channels on either side; the bar may continue to grow in the quieter water between these channels by the advance of small dunes on its surface. The downstream end of the bar may become pointed by the convergence of channels on either side, and the bar as a whole may become wedge shaped. Diversion of current around submersed bars creates braided patterns, observable on aerial photographs (fig. 17), that are the same as the patterns made by diversion around emersed bars and islands. Bars are built during a high river stage to heights that are above the water level during an average river stage. Some of these bars emerge when the river recedes, and they then become islands if vegetation grows on them (fig. 19) and prevents their destruction.

The valley flats (flood plains) of the North and Middle Loup Rivers are built by a modification of the lateral accretion process: islands are successively added to the valley flat as the course of the river shifts laterally. Many islands are separated from the valley flat by a single narrow channel that is dry during an average river stage. (See island at lower center, fig. 17.) Aerial photographs show many former islands that have become part of the valley flat by the disappearance of narrow channels which separated them from the flat. A succession of vegetation begins with weeds on recently emersed bars; weeds are replaced by willows as the bar becomes an island; and finally, after the island has become part of the valley flat, the 
willows are replaced by grass. Grassed areas that are still recognizable as former islands are higher than the younger willow-covered islands. This greater height cannot be attributed to a thicker accretion of overbank deposits that accumulated over a longer period of time because overbanks flows are rare in the upper courses of the North Loup and Middle Loup. Moreover, grassed former islands show a succession of heights as much as about 8 feet above present river level. This succession of heights is an indication of degradation by the river.

\section{MEASUREMENT AND DESCRIPTION OF CHANNEL PATTERNS}

According to the usage of Leopold and Wolman (1957), the term "channel pattern" applies to the plan view of a river reach and includes meandering, braided, and straight channels. The channel pattern of a river usually varies from place to place.

\section{MEANDERING AND SINUOSITY}

Leopold and Wolman (1957) computed the sinuosity of a reach as the ratio of thalweg length to valley length. Lane (1957) computed a "tortuosity ratio" as the ratio of the length of the stream channel to the length of the stream measured along the axis of the valley. Many rivers on broad valley floors have meander belts that are curved. For such rivers, the sinuosity that is a function of the size, shape, and repetition of individual channel arcs should be considered separately from the sinuosity that is a function of the curvature of the meander belt. Otherwise, a different measure of sinuosity would be obtained for two reaches whose channel arcs are identical but whose meander belts are differently curved. If the axis of a series of symmetrical sine curves is bent, the sinuosity as measured in relation to a straight line joining the ends of the axis is changed; but the radius of curvature of individual arcs remains the same. Figure 20 illustrates the delineation of the meander-belt axis, which passes through the inflection points of arcs. Individual channel arcs are thus delineated above and below the meander-belt axis. The channel sinuosity of a reach, here called the sinuosity index (S.I.), is the ratio of length of channel to length of meander-belt axis. Where no meander belt can be distinguished, the sinuosity index is the ratio of length of channel to length of valley axis. Sinuosity of a meander belt, if desired, may be determined from the ratio of length of meander-belt axis to length of valley axis.

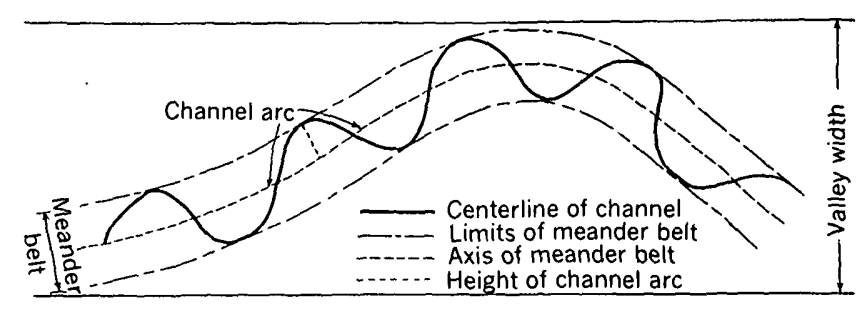

Fiours 20.-Delineation of meander belt, axis of meander belt, and channel ares for measurement of sinuosity and symmetry.

Sinuosity is easy to define and measure, but meandering is difficult to define and measure. A discussion and a definition of meandering are given by Lane (1957), and a summary of the geometry and hydraulics of river meandering is provided by Leopold and Wolman (1960). According to general usage, a meandering stream has a moderate to high degree of sinuosity, and the sinuosity is somewhat symmetrical. In defining meandering, some writers specify a migration of meander bends. Leopold and Wolman (1957) stipulated that meandering reaches have a greater sinuosity than irregularly sinuous reaches and that a sinuosity of 1.5 or greater indicates meandering. However, the use of sinuosity alone is not satisfactory for identification of a meander; on the basis of other criteria, these authors recorded a meander that has a sinuosity of 1.12 (Leopold and Wolman, 1960, p. 792). They reported consistent correlations between meander length and channel width; large rivers have large bends and small rivers have small bends, so that the general aspect of both large and small meandering rivers is similar in plan view.

The symmetry of a reach consisting of several channel arcs depends both on the properties of individual arcs and on the group properties of the sequence of arcs. An individual arc may be described by its mean radius; its form may be described by the ratio of length to height, which is here called the form ratio. The arc length is the length of the meander-belt axis that is intercepted by the arc, and the radius of an arc is approximately equal to half the arc length. Group properties of a sequence of arcs include the statistical variation in arc length, height, and form ratio, the regularity of repetition for arcs of average size and form, and the sinuosity of the meander-belt axis. The average arc height, length, and form ratio may be determined for a reach. The symmetry of the reach may then be compared with an ideal reach that consists of this average arc regularly repeated along a straight line of the same length as the actual meander-belt axis. If the consistency in size, form, and repetition of arcs in this ideal reach is con- 
sidered to be 100-percent symmetry, then the symmetry of the actual reach may be expressed as a percentage of 100 according to the following scheme:

Percentage symmetry of

$$
\begin{aligned}
& \text { arc length } \\
& =100-\frac{100 \text { (mean deviation of length) }}{\text { mean length }} \\
& \text { arc height } \\
& =100-\frac{100 \text { (mean deviation of height) }}{\text { mean height }} \\
& \text { form ratio } \\
& =100-\frac{100 \text { (mean deviation of form ratio) }}{\text { mean form ratio }}
\end{aligned}
$$

The aspect of symmetry that depends on the regular repetition of arcs can be expressed roughly by dividing the number of arcs of approximately average size in the actual reach by the number of arcs in the ideal reach. Arcs in the actual reach whose length does not deviate more than 25 percent from average length may be considered to be of approximately average size. Finally, the sinuosity of the actual meander-belt axis relative to the straight axis of the ideal reach may be expressed as a percentage by dividing the sinuosity into one, which is the sinuosity of a straight line.

In order to evaluate the significance of symmetry in the definition of meandering, measures of symmetry were applied to a reach of the river from whose name the term "meander" is derived-the Maiandros River in Turkey (now named the Buyuk Menderes). This reach, shown in figure 21 , is redrawn from a longer

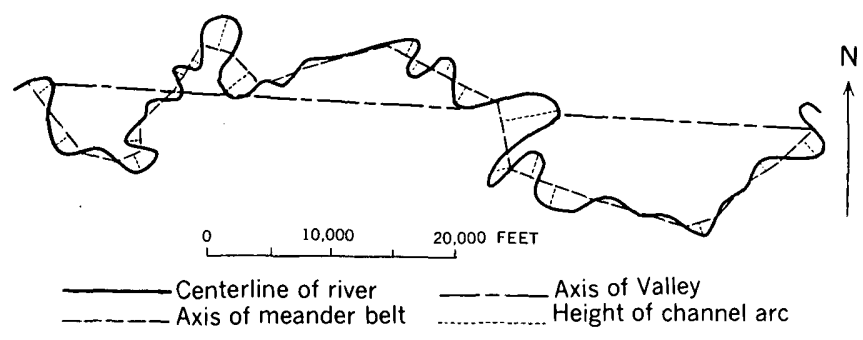

Figure 21.-Delineation of a reach of the Buyuk Menderes River, Turkey, for measurement of sinuosity and symmetry.

reach reproduced by Lane (1957) on a scale of 1 inch to 10,000 feet. Symmetry of the reach is perhaps adequately indicated by the following measures:

Arc length.-mean, 2,600 ft; mean deviation, 800 $\mathrm{ft}$; percent symmetry, 70 .

Arc height.-mean, $1,700 \mathrm{ft}$; mean deviation, 570 $\mathrm{ft}$; percent symmetry, 66 .

Form ratio.-mean, 1.8; mean deviation, 0.6; percent symmetry, 67 .
Repetition of arcs.-number of arcs of approximately average size, 10 ; number of arcs in ideal reach, 33 ; percent symmetry, 30 .

Straightness of meander-belt axis.-sinuosity, 1.3 ; percent straightness, 77.

Sinuosity index of channel.-1.56.

If these measures of symmetry are valid and if this reach is representative of the Buyuk Menderes, then the type example for meandering rivers has a rather low degree of symmetry. If symmetry is to be stipulated in applying the term "meandering" to randomly selected reaches, some arbitrary limit of symmetry will have to be established. No simple and rapid means of expressing symmetry quantitatively is apparent although a great many different ways of expressing symmetry could be devised.

An experiment carried out by Friedkin (1945, p. 15) indicated that a minor lack of homogeneity in bank materials has a pronounced effect on both symmetry and sinuosity. When a small percentage of cement was distributed unevenly through the bank materials, a laboratory river developed low symmetry and a sinuosity index of 1.17, as compared with a high symmetry and a sinuosity of 1.4 for a similar laboratory river in homogeneous bank materials.

In this report, sinuous reaches are described by means of the sinuosity index, and no attempt is made to describe the symmetry of the sinuosity. If the sinuosity index of a reach is 1.3 or greater, the reach is further described as meandering, whether the sinuosity is symmetrical or not. Ideally, a straight reach has a sinuosity index of 1 , but reaches that have sinuosity indices of less than 1.05 are described as straight. Reaches that have sinuosity indices between 1.05 and 1.3 are described as sinuous. The term "meandering" is more satisfactory for the description of a stream course in general than for the description of short randomly selected reaches. The term "meandering" thus is applied to a sinuous stream that has, from place to place along its course, one or a series of symmetrical arcs, the length of which is related to the width of the stream.

The sinuosity index is greatly influenced by the choice of reaches to be measured. Few streams meander continuously along their courses, and very sinuous reaches are usually separated by less sinuous reaches. If the reach to be measured is restricted to the more sinuous parts, then a higher sinuosity index will obviously be obtained than if the reach is extended beyond the more sinuous parts. In this study, reaches were not selected on the basis of channel pattern but on the basis of location at a gaging station. Each 
reach is about 2 miles in length along the stream and extends about 1 mile upstream and about 1 mile downstream from a gaging station. If the sinuosity index of a reach chosen in this way is about 1.3 or greater, the reach is meandering in the sense that seems to be generally accepted. For example, the small-scale rivers considered to be meandering by Friedkin (1945, pls. 33,41 ) have sinuosity indices of 1.25-1.3.

\section{BRAIDING}

Leopold and Wolman (1957) defined a braided river as " $* * * *$ one which flows in two or more anastomosing channels around alluvial island." Friedkin (1945) stipulated that the braided channel is extremely wide and shallow and that the flow passes through a number of small interlaced channels separated by bars. According to Lane (1957), “*** a braided stream is characterized by having a number of alluvial channels with bars or islands between meeting and dividing again, and presenting from the air the intertwining effect of a braid." Also, Lane proposed a genetic classification of braided streams in which the major categories are "braiding due to steep slope" and "braiding due to aggradation." Within each major category, streams are further classified according to whether they are degrading, at equilibrium, or aggrading. The term "multiple channel streams" was proposed by Lane to include not only streams having a distinctly braided appearance but also streams having scattered islands (such as the lower Illinois River). Also included are distributaries on deltas and anastomosing distributaries on deltas and on alluvial fans.

The term "multiple channel" has much merit, but the classification of multiple-channel streams on a purely genetic basis is impractical. The causes of braiding are poorly understood, and a sound descriptive classification is a first step toward understanding braiding. Several descriptive features of probable genetic significance and of use in descriptive classification may be suggested. One such feature is the size of the islands relative to the width of the channel. Small islands are probably formed by the growth of bars in the channel whereas very large islands are more likely formed by diversion and splitting of the channel during overbank discharge, as in the crevassing of the natural levees of delta distributaries. The location of islands near the entrance of minor tributaries probably has genetic significance, as Rubey (1952) suggested. High sinuosity of individual channels of braided streams, together with the presence of lakes and undrained depressions on islands, may be characteristic of low-slope braided streams such as the Upper Mississippi River near Waukon, Iowa.
No scheme for describing quantitatively the braided pattern of a reach or for distinguishing between braided and not braided reaches was found in the literature. Leopold and Wolman (1957) specified that islands develop from bars that emerge and become stabilized by vegetation. The presence or absence of vegetal cover seems to be the only practical criterion for distinguishing an island from a bar in the field and on aerial photographs. As defined here, an island has vegetal cover and is ordinarily emersed during a bankfull stage; a bar has no vegetal cover and is ordinarily submersed during a bank-full stage, but it may be emersed during lower stages. Braiding that changes in pattern with river stage is characterized by bars and is termed "transient." Braiding that remains nearly constant in pattern is characterized by islands and is termed "stabilized." The following ratio, called the braiding index (B.I.), has been found satisfactory for description of channel braiding, either transient or stabilized :

$$
\text { B.I. }=\frac{2 \text { [sum of lengths of islands and (or) bars in reach }]}{\text { length of reach measured midway between banks }}
$$

The braiding index is a measure of the sum of island or bar perimeters in a reach and hence of the increase in bank length that results from braiding. Most islands or bars are narrow, and their perimeters are approximately twice their lengths. Lengths of islands or bars in a reach can be measured and summed in the same operation by use of a chartometer (map measure). The stabilized-braiding index is determined by measuring islands only; the transient-braiding index, by measuring bars only; and the total-braiding index, by measuring both islands and bars or by adding the other two indices. Submersed bars are not measured. Aerial photographs are much more satisfactory than topographic maps for measurement of the braiding index because the braided channel pattern is conventionalized on many topographic maps. Also, the representation of a particular feature in the channel as an island or as a bar depends on the judgment of the cartographer. Bars are not shown on many maps.

The stabilized-braiding index for a particular reach should remain nearly constant for different river stages whereas the transient-braiding index will change greatly with changing river stage. A decision must be made as to which index of braiding - transient, stabilized, or total-most satisfactorily represents the channel morphology of a particular river. For the Loup Rivers, the total-braiding index was used because both bars and islands are characteristic features 
of the river channels. A reach that is both meandering and braided may be described by using both the sinuosity index and the braiding index.

Although the braiding index as defined herein is useful for morphologic description, it has little quantitative hydraulic significance. The braiding index has no consistent relation to water width, which is, as previously shown for the Middle Loup at Dunning, the dimension to which hydraulic variables can be related. The writer was not able to devise a braiding measure that has both morphologic and hydraulic significance.

Distinction between braided reaches and reaches having few islands or bars is arbitrary, but a consistent distinction may be made by means of an appropriate value of the braiding index. For the Loup Rivers, a value of 1.5 for the total-braiding index was selected to distinguish braided from not braided reaches, because reaches having an index of less than 1.5 did not have a braided appearance. The braiding index, like the sinuosity index, is influenced by the choice of reaches: short reaches that are restricted to the vicinity of islands will have a higher braiding index than long reaches sampled at random. Most of the bias that results from the selection of short reaches can be avoided by specifying an adequate reach length in terms of bankfull widths; for example, a reach having a length equal to 10 bank-full widths would probably be satisfactory. The braiding indices shown in table 2 apply to reaches about 2 miles long, extending about 1 mile upstream and 1 mile downstream from each gaging station.

Channel patterns of reaches having different indices of braiding and sinuosity are illustrated in figures 22 and 23. These reaches were selected to illustrate the range of channel patterns of the Loup Rivers and do not correspond exactly to the reaches referred to in table 2.

TABLE 2.-Values of hydraulic factors at gaging stations in the Loup River basin

\begin{tabular}{|c|c|c|c|c|c|c|c|c|c|c|c|c|c|c|c|c|c|}
\hline \multirow[b]{2}{*}{ Gaging station } & \multirow{2}{*}{$\begin{array}{l}\text { A ver- } \\
\text { age dis- } \\
\text { charge } \\
\text { for } \\
\text { period } \\
\text { of } \\
\text { record } \\
\text { to } 1957 \\
\text { (cfs) }\end{array}$} & \multirow{2}{*}{$\begin{array}{c}\text { Num- } \\
\text { ber of } \\
\text { years of } \\
\text { record } \\
\text { to } 1957\end{array}$} & \multirow{2}{*}{$\begin{array}{l}\text { Aver- } \\
\text { age of } \\
\text { maxi- } \\
\text { mum } \\
\text { daily } \\
\text { dis- } \\
\text { charges } \\
\text { (cis) }\end{array}$} & \multirow{2}{*}{$\begin{array}{c}\text { Coeffi- } \\
\text { cient of } \\
\text { devia- } \\
\text { tion, } \\
\text { dis- } \\
\text { charge }\end{array}$} & \multirow[b]{2}{*}{$\begin{array}{c}\text { Mean } \\
\text { width } \\
\text { (feet) }\end{array}$} & \multirow{2}{*}{$\begin{array}{l}\text { Stand- } \\
\text { ard } \\
\text { devia- } \\
\text { tion, } \\
\text { width } \\
\text { (feet) }\end{array}$} & \multirow{2}{*}{$\begin{array}{l}\text { Coeffi- } \\
\text { clent of } \\
\text { varia- } \\
\text { tion } \\
\text { width } \\
\text { (per- } \\
\text { cent) }\end{array}$} & \multirow{2}{*}{$\begin{array}{l}\text { Chan- } \\
\text { nel } \\
\text { slope 1 } \\
\text { (ft per } \\
\text { ft) }\end{array}$} & \multicolumn{3}{|c|}{ Index of braiding } & \multirow[b]{2}{*}{$\begin{array}{l}\text { Index } \\
\text { of sinu- } \\
\text { osity }\end{array}$} & \multicolumn{2}{|c|}{$\begin{array}{c}\text { Suspended sedl- } \\
\text { ment }\end{array}$} & \multicolumn{3}{|c|}{ - Bed material } \\
\hline & & & & & & & & & Total & $\begin{array}{l}\text { Stabi- } \\
\text { lized }\end{array}$ & $\begin{array}{l}\text { Tran- } \\
\text { sient }\end{array}$ & & $\begin{array}{l}\text { Concen- } \\
\text { tration } \\
(\mathrm{ppm})^{2}\end{array}$ & $\begin{array}{l}<0.062 \\
\text { mm } \\
\text { (per- } \\
\text { cent) }\end{array}$ & $\begin{array}{c}<0.062 \\
\text { mm } \\
\text { (per- } \\
\text { cent) }\end{array}$ & $\begin{array}{l}<0.50 \\
\text { mm } \\
\text { (per- } \\
\text { cent) }\end{array}$ & $\begin{array}{l}\underset{\operatorname{mm}}{\text { (per- }} \\
\text { cent) }\end{array}$ \\
\hline $\begin{array}{l}\text { Middle Loup River: } \\
\text { 1. Near Seneca..... } \\
\text { 2. At Dunning.... }\end{array}$ & $\begin{array}{l}201 \\
385\end{array}$ & $\begin{array}{r}4 \\
12\end{array}$ & $\begin{array}{l}308 \\
570\end{array}$ & & $\begin{array}{l}100 \\
160\end{array}$ & & & $\begin{array}{l}0.00137 \\
.0013\end{array}$ & $\stackrel{<0.1}{<.1}$ & $\stackrel{<0.1}{<.1}$ & $\stackrel{<0.1}{<.1}$ & $\begin{array}{l}1.3 \\
1.06\end{array}$ & $\begin{array}{l}1770 \\
8800\end{array}$ & & & & (n) \\
\hline $\begin{array}{l}\text { Dismal River: } \\
\text { 3. At Dunning.... }\end{array}$ & 316 & 12 & 460 & & 80 & & & .0013 & $<.1$ & $<.1$ & $<.1$ & 1.3 & 1940 & & & & \\
\hline $\begin{array}{l}\text { Middle Loup River: } \\
\text { 4. Near Milburn... } \\
\text { 5. At Walworth.... } \\
\text { 6. At Sargent } \\
\text { 7. At Arcadia } \\
\text { 8. At Loup City. } \\
\text { 9. At Rockville..... }\end{array}$ & $\begin{array}{l}786 \\
799 \\
813 \\
799 \\
823 \\
804\end{array}$ & $\begin{array}{r}5 \\
12 \\
5 \\
12 \\
7 \\
2\end{array}$ & $\begin{array}{l}1,250 \\
1,550 \\
1,470 \\
2,580 \\
2,000 \\
4,340\end{array}$ & $\begin{array}{l}0.16 \\
.38 \\
.21 \\
.81 \\
.40\end{array}$ & $\begin{array}{l}345 \\
530 \\
595 \\
320 \\
587 \\
\mathbf{5 8 1}\end{array}$ & $\begin{array}{r}98 \\
229 \\
175 \\
185 \\
155 \\
113\end{array}$ & $\begin{array}{l}28.4 \\
43.2 \\
29.4 \\
57.8 \\
26.4 \\
19.4\end{array}$ & $\begin{array}{l}.00156 \\
.00159 \\
.00135 \\
.00120 \\
.00131 \\
.00127\end{array}$ & $\begin{array}{l}1.0 \\
1.8 \\
2.2 \\
2.5 \\
2.5 \\
2.3\end{array}$ & $\begin{array}{r}.2 \\
.9 \\
.5 \\
1.2 \\
<.1 \\
.4\end{array}$ & $\begin{array}{r}.8 \\
.9 \\
1.7 \\
1.3 \\
2.5 \\
1.9\end{array}$ & $\begin{array}{l}1.05 \\
1.06 \\
1.05 \\
1.07 \\
1.15 \\
1.06\end{array}$ & $\begin{array}{r}4820 \\
4900 \\
1,100 \\
1,250 \\
41,200 \\
1,250\end{array}$ & $\begin{array}{l}17 \\
23\end{array}$ & 0 & 91 & \begin{tabular}{l}
92 \\
\hdashline 99 \\
99
\end{tabular} \\
\hline $\begin{array}{l}\text { South Loup River: } \\
\text { 10. Near Cumro... } \\
\text { 11. At Ravenna.... } \\
\text { 12. At St. Michael... }\end{array}$ & $\begin{array}{l}165 \\
198 \\
248\end{array}$ & $\begin{array}{r}7 \\
12 \\
12\end{array}$ & $\begin{array}{l}1,535 \\
3,645 \\
4,830\end{array}$ & $\begin{array}{r}.91 \\
.81 \\
1.06\end{array}$ & $\begin{array}{l}119 \\
205 \\
209\end{array}$ & $\begin{array}{l}26 \\
63 \\
52\end{array}$ & $\begin{array}{l}23.2 \\
30.7 \\
24.9\end{array}$ & $\begin{array}{l}.00083 \\
.00108 \\
.00096\end{array}$ & $\begin{array}{r}<.1 \\
.5 \\
.5\end{array}$ & $\begin{array}{l}<.1 \\
<.1 \\
<.1\end{array}$ & $\begin{array}{l}.1 \\
.5 \\
.5\end{array}$ & $\begin{array}{l}2.4 \\
1.6 \\
1.4\end{array}$ & $\begin{array}{l}42,100 \\
43,000 \\
63,170\end{array}$ & 81 & 1.0 & 92 & 99 \\
\hline $\begin{array}{l}\text { North Loup River: } \\
\text { 13. At Brewster...... } \\
\text { 14. At Taylor } \\
\text { 15. At Burwell........... }\end{array}$ & $\begin{array}{l}378 \\
448 \\
485\end{array}$ & $\begin{array}{r}6 \\
12 \\
5\end{array}$ & $\begin{array}{r}830 \\
1,120 \\
1,215\end{array}$ & $\begin{array}{l}.29 \\
.41 \\
.46\end{array}$ & $\begin{array}{l}267 \\
270 \\
320\end{array}$ & $\begin{array}{l}98 \\
93 \\
90\end{array}$ & $\begin{array}{l}36.7 \\
34.4 \\
28.1\end{array}$ & $\begin{array}{l}.00119 \\
.00133 \\
.00147\end{array}$ & $\begin{array}{l}.8 \\
1.5 \\
1.6\end{array}$ & $\begin{array}{l}.3 \\
.7 \\
.3\end{array}$ & $\begin{array}{r}.5 \\
.8 \\
1.3\end{array}$ & $\begin{array}{l}1.04 \\
1.03 \\
1.15\end{array}$ & $\begin{array}{l}4510 \\
4600 \\
4680\end{array}$ & $\begin{array}{c}19 \\
23\end{array}$ & .1 & 69 & \\
\hline $\begin{array}{l}\text { Calamus River: } \\
\text { 16. Near Burwell.... } \\
\text { 17. Near Harrop... }\end{array}$ & $\begin{array}{l}288 \\
250\end{array}$ & ${ }_{(8)}^{12}$ & $\begin{array}{l}550 \\
450\end{array}$ & .19 & $\begin{array}{r}170 \\
67\end{array}$ & $\begin{array}{l}43 \\
19\end{array}$ & $\begin{array}{l}25.3 \\
28.4\end{array}$ & $\begin{array}{l}.00109 \\
.00102\end{array}$ & .2 & $\begin{array}{l}.2 \\
.1\end{array}$ & $<.1$ & $\begin{array}{l}1.05 \\
1.6\end{array}$ & ${ }^{4} 360$ & 29 & .1 & 73 & 91 \\
\hline $\begin{array}{l}\text { North Loup River: } \\
\text { 18. At Ord... } \\
\text { 19. At Scotia. } \\
\text { 20. Near Cotesfield.. } \\
\text { 21. Near St. Paul... }\end{array}$ & $\begin{array}{l}826 \\
828 \\
903 \\
888\end{array}$ & $\begin{array}{r}5 \\
12 \\
6 \\
12\end{array}$ & $\begin{array}{l}2,250 \\
4,250 \\
4,300 \\
5,850\end{array}$ & .58 & $\begin{array}{l}453 \\
515 \\
417 \\
501\end{array}$ & $\begin{array}{l}140 \\
125 \\
113 \\
108\end{array}$ & $\begin{array}{l}30.9 \\
24.3 \\
27.1 \\
21.6\end{array}$ & $\begin{array}{l}.00110 \\
.00121 \\
.00120 \\
.00107\end{array}$ & $\begin{array}{l}1.7 \\
1.5 \\
1.2 \\
1.5\end{array}$ & $\begin{array}{r}.4 \\
<.7 \\
<.1\end{array}$ & $\begin{array}{l}1.3 \\
.8 \\
1.2 \\
1.5\end{array}$ & $\begin{array}{l}1.06 \\
1.09 \\
1.04 \\
1.2\end{array}$ & $\begin{array}{r}1800 \\
41,000 \\
11,100 \\
81,430\end{array}$ & $\begin{array}{l}28 \\
62\end{array}$ & $\begin{array}{l}0 \\
2.0 \\
0\end{array}$ & $\begin{array}{l}75 \\
75\end{array}$ & 97 \\
\hline $\begin{array}{l}1 \text { Measured from topo } \\
2 \text { Discharge weighted. } \\
3 \text { A verage of samples. }\end{array}$ & & & & & & & & & & 1 & & & & & & & \\
\hline
\end{tabular}


A.-CALAMUS RIVER NEAR BURWELL. OCT 22, 1949
(TOTAL B.1.. 0.2:S.1., 1.05)

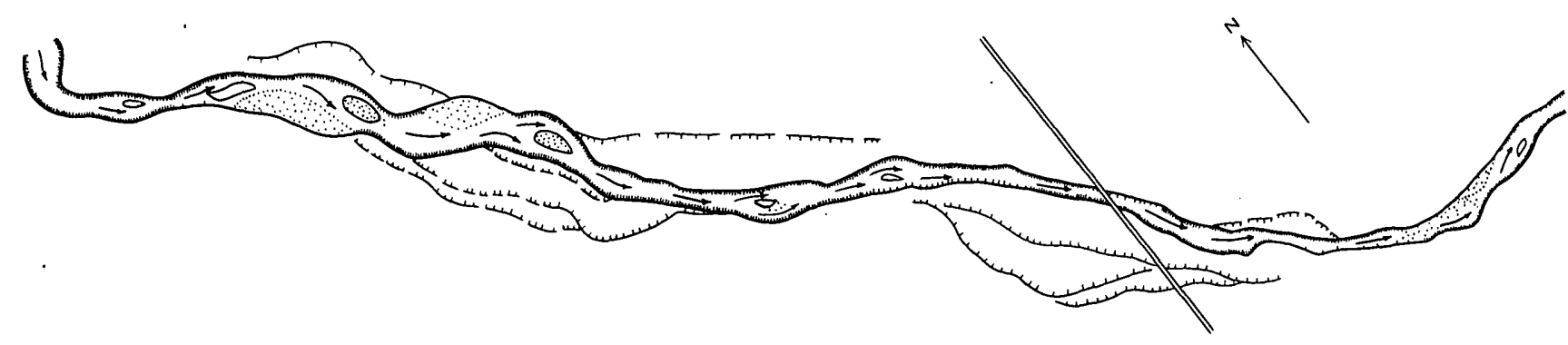

B.-NORTH LOUP RIVER UPSTREAM FROM TAYLOR,
OCT 22.1949 (TOTAL B. I., 1.6:STABILIZED B. I., 1.3;
S.I., 1.1)

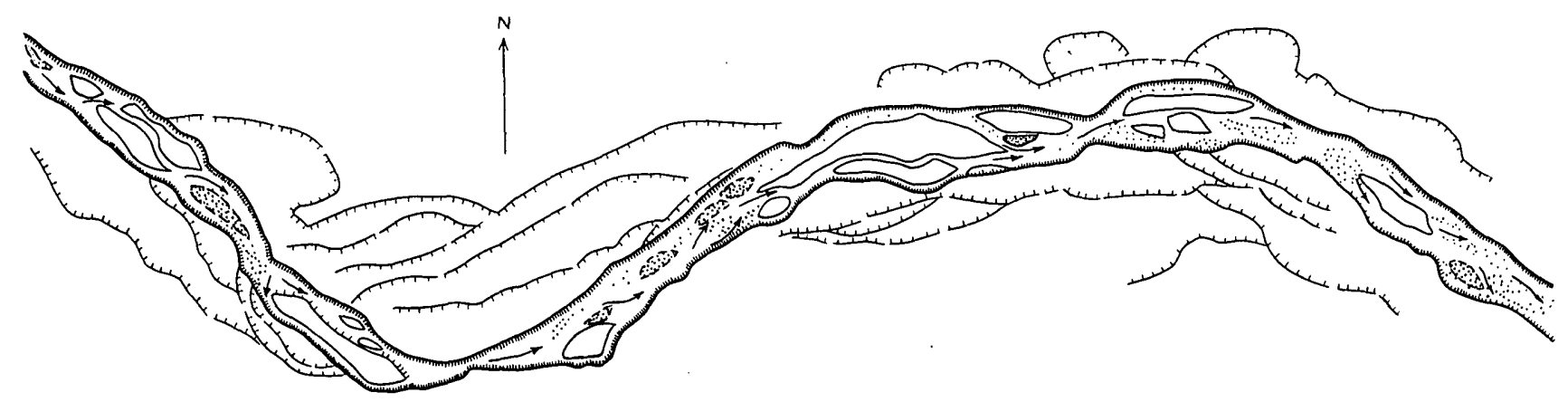

C.-MIDDLE LOUP RIVER UPSTREAM FROM ARCADIA, OCT 24,1949 (TOTAL B. 1., 2.7; STABILIZED B. I.. 1.1:

S. 1., 1.05)
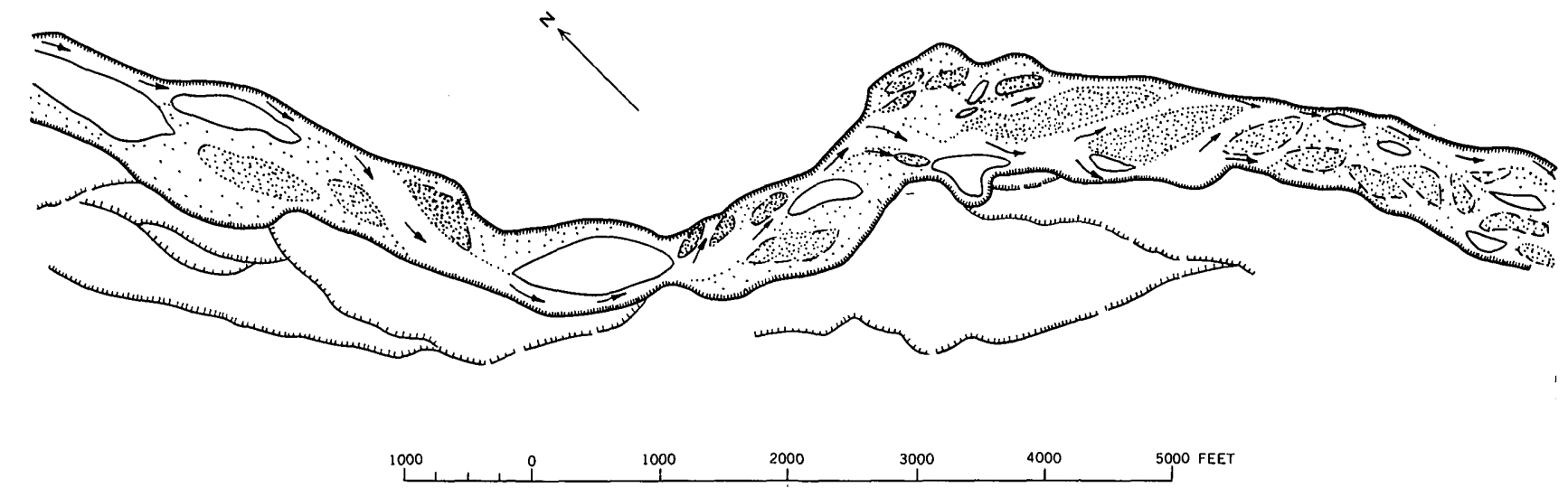

FIGURE 22.-Reaches that lllustrate different values of the braiding index. Sandbars are shown in stippled pattern, islands are blank, and scarps of minor cut terraces are hachured. Traced from aerial photographs. 
A.-CALAMUS RIVER NEAR HARRUP, OCT 28, 1949 (S. I., 1.7; TOTAL B. 1., O.O8)

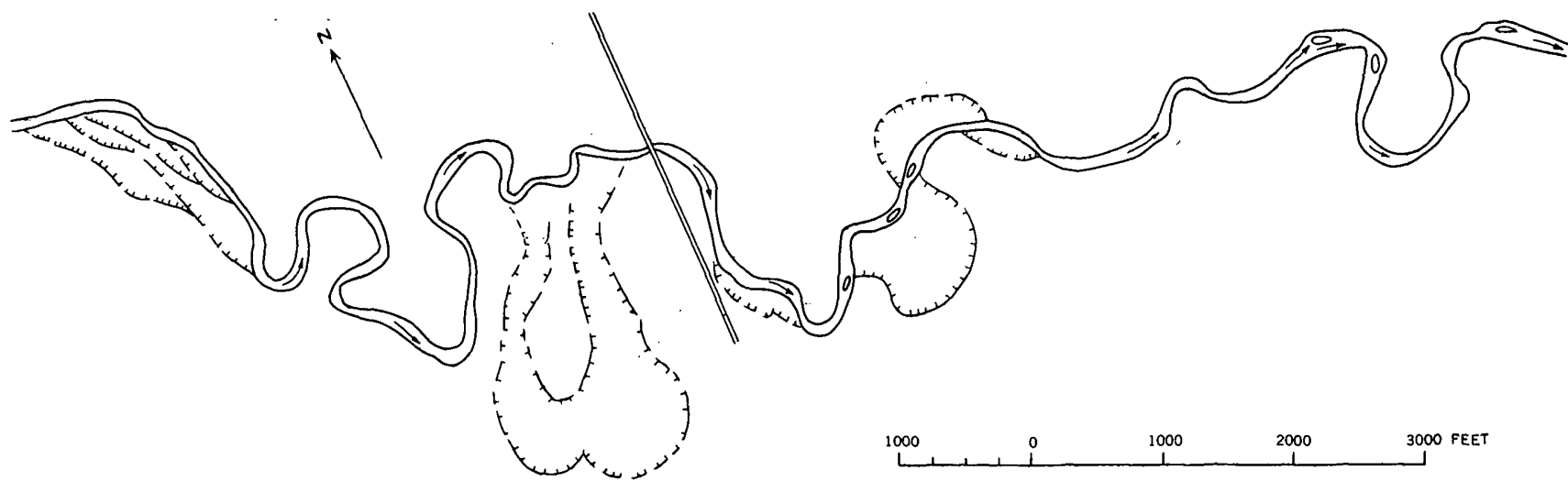

\section{B.-SOUTH LOUP RIVER IN VICINITY OF CUMRO} OCT 11.1949 (S. I., 2.1)

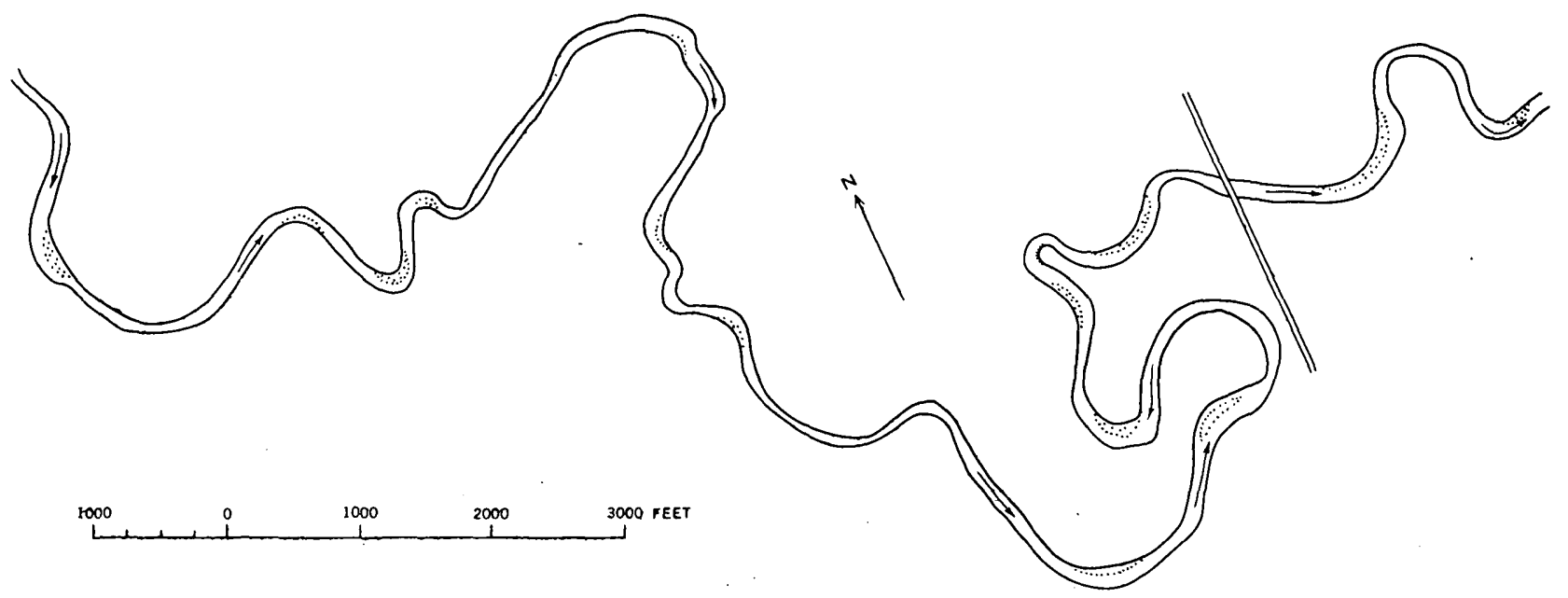

C.-SOUTH LOUP RIVER AT ST. MICHAEL, NOV 8, 1951

(S. I., 1.6; TOTAL B. I., 0.5)

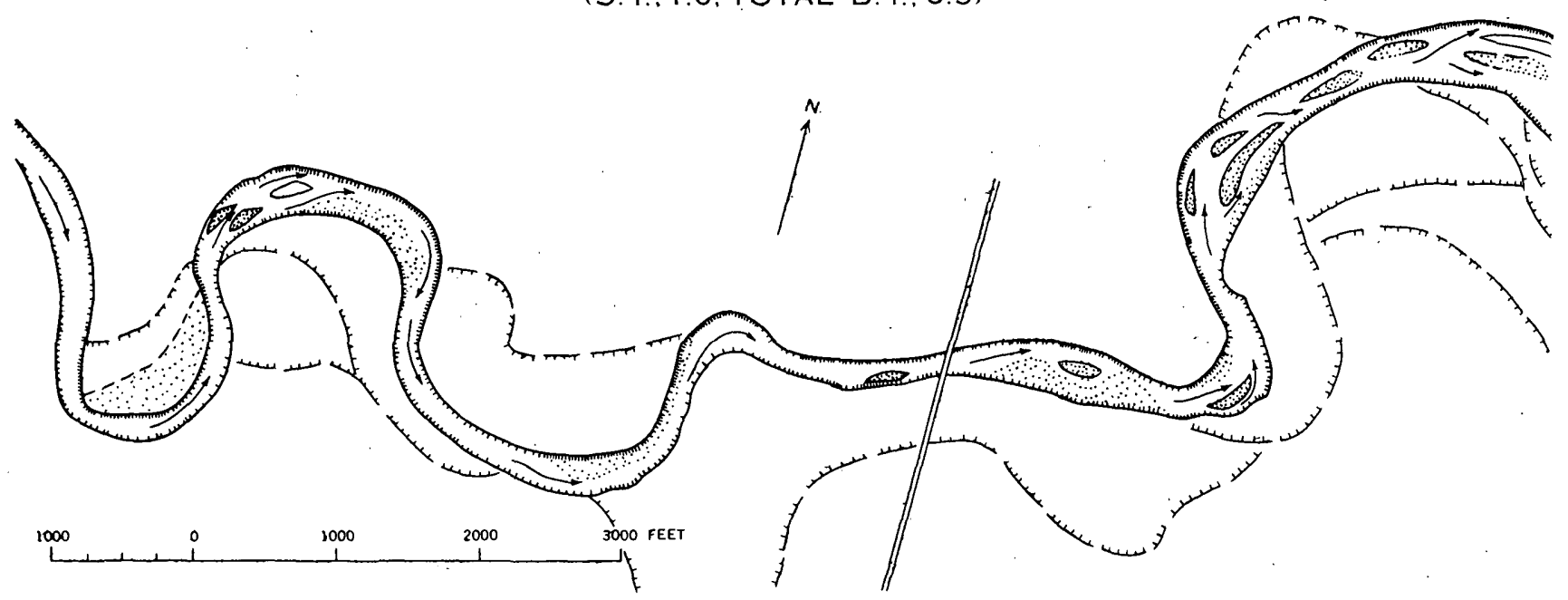

Froune 23.-Reaches that lllustrate different values of the sinuosity index. Sandbars are shown in stippled pattern, islands are blank, and scarps of minor cut terraces are hachured. Traced from aerial photographs. 


\section{WIDTH}

For each of the gaging stations listed in table 2, except Middle Loup River near Seneca, river width at the gaging station, at six sections upstream, and at six sections downstream was measured on aerial photographs. Width of the Middle Loup near Seneca was measured on a Geological Survey topographic map. Sections were spaced about 800 feet apart; therefore, the reach between the end sections was about 9,600 feet in length. Mean width for each 9,600-foot reach was determined from the 13 individual measurements of width. At each section, width was measured between river banks, which are stabilized by vegetation and are clearly shown on the aerial photographs. For braided reaches, the widths of vegetated islands were not included in river width; therefore, the river widths represent the total widths of the stabilized channels. The widths of unvegetated sandbars in the channel, whether emersed or submersed, were included in the measurement of channel width. The widths as measured thus differ from the effective widths reported by Hubbell and Matejka (1959) for the Middle Loup at Dunning; there emersed sandbars were excluded from measurements of width. Coefficients of width variation, as determined by dividing standard deviation by mean width, range from about 19 percent to about 58 percent.

\section{CHANNEL PATTERNS OF THE LOUP RIVERS}

A general impression of the sinuosity of the Loup Rivers may be obtained from figures 8,9 , and 10 by comparing each river profile with the corresponding valley profile. For a given reach, the ratio of valley slope to river-channel slope equals the sinuosity index; and where the two slopes are nearly parallel, the reach is nearly straight. At most places along the North Loup and Middle Loup, no meander belt can be distinguished; and the valley width, which includes the width of the Elba terrace surface, is no more than 20 times the width of the river. The maximum width of the South Loup valley is nowhere more than twice the width of the meander belt. For the Loup Rivers, therefore, slope of meander belt and slope of valley axis are nearly equal.

The North Loup has a sinuosity index of about 1.6 in its upper reaches. This value gradually decreases downstream, and below. Brewster the sinuosity is so low that the valley slope and stream slope are nearly parallel. Symmetrical, well-defined meanders are present only in a short reach near Brewster and in a reach near the confluence with the Middle Loup. Most of the lower 130 miles of the North Loup trends in broad arcs (S.I. $=1.1-1.05$ ) or in nearly straight reaches (S.I. =
1.01-1.05) that commonly meet to form a right-angle bend. Scattered islands divide the channel from place to place, but in general the North Loup is only slightly braided. The reach at Ord (total B.I., 1.7; stabilized B.I., 0.4) is typical of the more braided reaches of the river. For the reaches measured at gaging stations (table 2), the average total B.I. is 1.4 and the average stabilized B.I. is 0.4 .

According to Leopold and Wolman (1957), extremely short reaches of a channel may be straight, but reaches that are straight for distances exceeding 10 times the channel width are rare. They did not specifically define what is meant by a straight channel, but the straight channels in their illustrations show a slight degree of sinuosity. Long reaches that have a sinuosity index of less than 1.01 are fairly eommon along the North Loup and Middle Loup. A reach of the North Loup downstream from Scotia is $2 \frac{1}{2}$ miles long (a distance of about 30 times river width) and has a sinuosity index of 1.01. The straightness of Loup River reaches may be exceptional.

In general, the Middle Loup is somewhat less sinuous than the North Loup and somewhat more braided. Both of these rivers have a low degree of braiding as compared with a river such as the Platte. In a 2-mile reach near the village of Silver Creek, Nebr., the Platte had a total braiding index of about 8 on May 2, 1951. For the reaches measured at Middle Loup gaging stations, the average total B.I. is 1.6 and the average stabilized B.I. is 0.4 . Although a comparison of the North Loup and Middle Loup as represented on Geological Survey topographic maps (scale 1:24,000 issued 1951-55) would indicate that the Middle Loup is much more highly braided than the North Loup, no great difference between the rivers could be seen on the aerial photographs from which the maps were made. The maps were evidently drawn by different cartographers who had different opinions about the representation of a braided stream. The Middle Loup is moderately sinuous in its upper reaches, but the parallelism of its stream slope and valley slope (fig. 9 ) shows that its sinuosity is generally very low. A few symmetrical meander arcs may be seen in the river course near Dannebrog and at Boelus, but otherwise the sinuosity of the Middle Loup shows little symmetry.

The sinuosity of the South Loup is apparent from a comparison of its river slope with its valley slope (fig. 10). Except for the reach between elevations 2,000 and 2,150 feet, which has a steep slope and low sinuosity, the average sinuosity index of the river is about 1.4. The degree of symmetry shown by most reaches is represented by figure $23 B$; but a higher symmetry, 
represented by figure $23 C$, is possessed by a few reaches. Channel arcs gradually increase in size downstream as water discharge and river width increase. (See figs. 23B,C.) Small vegetated islands and emersed bars occur from place to place in the channel of the South Loup, particularly in the lower 20 miles of its course; but the degree of braiding is generally very slight.

Most of the smaller flowing tributaries in the Sandhills (such as Goose Creek, which enters the North Loup upstream from Brewster) are meandering. The Calamus River meanders for most of its course, but the last 7 miles upstream from its confluence with the North Loup is characterized by wide, nearly straight reaches that contain abundant sandbars. In the loessmantled part of the Loup River basin, most tributaries (such as Clear Creek, Oak Creek, and Mud Creek) are meandering, and the meanders seem to be incised.

Channel stability of the North Loup River was studied by comparing aerial photographs made in August 1938 with photographs made in May 1957. Measurements were made on photographs of a reach near Ord, Nebr. Islands in this reach showed no measurable change in size, number, or position during the 19-year interval. The pattern of sandbars was of smaller scale and greater complexity on the 1938 photograph. The outside of a bend had migrated laterally by about 80 feet in 19 years, but the inside of the same bend showed little change. A straight reach showed a maximum of about 50 feet of lateral migration at one place, but at most places the river banks showed little change.

\section{RELATION OF SELECTED HYDRAULIC FACTORS TO CHANNEL PATTERN}

Lane (1957) discussed the factors affecting streamchannel form or shape. He did not specifically define the terms "channel form" and "channel shape," but he used these terms interchangeably to mean the aspects of a stream channel in plan view and in cross profile. Since his paper mainly is on the aspect of a stream channel in plan view, his conclusions about channel form readily apply to channel pattern. According to Lane, the major factors that affect channel form are water discharge, longitudinal slope, sediment load, resistance of bed and banks to scour by flowing water, vegetation, temperature, geology, and work of man. Some of these factors influence channel form directly; some, indirectly. In selecting the fewest factors for adequate differentiation of channel forms, Lane considered not only the relative magnitude of the effect of each factor but also both the feasibility of expressing each quantitatively and the availability of data for each. A major objective of his paper is to show that differences in channel form can be satisfactorily explained by differences in slope, bed-bank material, and average discharge.

The factors described by Lane are undoubtedly the major variables in the determination of channel pattern; and his selection of slope, bed-bank material, and average discharge as adequate variables for explaining channel pattern is reasonable. However, the usefulness of average discharge may depend on its correlation with other measures of discharge (such as bank-full discharge), inasmuch as an average discharge will not move the bed or bank material of many streams (M. G. Wolman, written communication, 1961). The writer regards bank erodibility as the most significant single variable, and bank erodibility depends mainly on the particle size of bank material and on vegetal growth along the banks.

The influence of diversion dams on channel patterns of the Loup Rivers has not been evaluated in this report. Diversion dams for irrigation have been built on the North Loup near Taylor, Burwell, and Ord and on the Middle Loup near Sargent and Arcadia. In addition, the Boelus Power Canal diverts water from the Middle Loup into the South Loup near the confluence of the two rivers. Most of the irrigation works have been built since 1945, although the Boelus Power Canal has been in operation since 1936. Comparison of river reaches immediately upstream from diversion dams with reaches immediately downstream indicates that the diversion has had little effect on previously established bank-full widths or on vegetated islands.

\section{BANK ERODIBILITY}

Loup River banks are typically low and overgrown by grass or other vegetation, but cut banks were found and examined at many localities. The banks of the North and Middle Loup Rivers are dominantly of sand. The sand generally contains streamers of fine gravel. Most cut banks contain a few layers of silty sand; and in several places, layers of dark clayey sand, probably deposited under swampy conditions, were seen. The low banks and point-bar deposits of the South Loup are of silty sand but in many places the Elba terrace deposits, against which the river has cut laterally, are mainly of silt and clay. The generally meandering pattern of the South Loup is attributed to the silt and clay content of its banks; such a content gives these banks a moderate degree of resistance to erosion. In comparison with the North Loup and Middle Loup, the much higher content of particles less than 0.062 millimeter in diameter in the suspended load of the South Loup, as well as the higher suspended-sediment con- 
centration, is considered to be a satisfactory indication of the higher silt and clay content of the South Loup's bank materials.

Schumm (1960) reported a relation between the width/depth ratio of a channel and the silt-clay content of its bed and banks. As the percentage of silt and clay in the bed and banks increases, the channel becomes deeper and narrower. In a later paper (1963), Schumm showed, for some alluvial rivers on the Great Plains, that sinuous channels are characterized by a high percentage of silt and clay in their perimeters. The writer was unable to devise a sampling procedure that would give a significant representation of the silt-clay content of banks along the Loup Rivers. The cohesive effect of silt and clay depends not only on its amount but also on its distribution in the bank materials. For example, silt and clay concentrated in layers gives a very different cohesive effect than would the same amount of silt and clay distributed uniformly through the bank materials.

No attempt has been made to describe quantitatively the influence of vegetation on bank erodibility, but this influence is significant. In the Sandhills, where the water table is high, swamp vegetation grows along the river courses and confines the channels. The meandering of the courses of the Calamus River and minor flowing tributaries in the Sandhills is attributed to the influence of swamp vegetation, which decreases bank erodibility.

The ability of bank materials to confine a stream depends partly on the discharge of the stream. As the discharge of a stream increases, the depth and mean velocity increase, and the banks not only are higher but also are subjected to greater erosive action. For bank materials of a given cohesiveness, a small stream would be expected to have a channel of lower width/depth ratio than a large stream.

The Calamus River is described in detail because it exhibits variations in channel pattern that are attributed to the influence of vegetation on bank erodibility. The major factors that influence channel pattern, except the factor of vegetation, seem to be constant. For a distance of about 7 river miles upstream from its confluence with the North Loup, the Calamus has low sinuosity and is slightly braided (fig. 22A). Farther upstream, the Calamus becomes distinctly meandering (fig. 23A). Discharge measurements for a section near Harrop, which is about 25 miles upstream from the confluence, and for another section near the confluence at Burwell show that discharge over the lower 25 miles of the river course is nearly constant. (See table 2.) Bank materials are derived from dune sand and are uniform from place to place:
Differences in bank erodibility are attributed to differences in vegetal growth along the banks; swamp vegetation is denser along the upper course of the river, probably because of the higher water table. The water table is higher along the upper course of the river because the sand dunes that border the river valley are higher than those along the lower course, which is near the edge of the Sandhills. At some places within the Sandhills, such as near Ashby, Nebr., the water table stands sufficiently high that flat areas between the dunes are marshy or are occupied by lakes.

The long profile of the lower 25 miles of the Calamus is shown in figure 24. The profile was drawn from Geological Survey topographic maps (scale, 1:24, 000; contour interval, $10 \mathrm{ft}$ ), and plotted points represent locations at which successive 10-foot contours cross the river. The slope is about 0.0011 foot per foot for the entire 25-mile river profile except for two minor bulges in the profile. The valley slope is slightly steeper in the upper part of the profile. Sinuosity indices and mean widths were measured on the topographic maps for 15 reaches, each of which is bounded by successive 10 -foot contour lines and represents a 10-foot drop in altitude and a horizontal distance of about 10,000 feet along the river. The reaches range in sinuosity index from 1.01 to 2.1 , and they range in mean width from 50 to 300 feet. The wider reaches, which are within 5 miles of the confluence, are slightly braided (braiding index, about 0.1 ) but contain numerous submersed sandbars.

River slope of the Calamus, as measured on the topographic maps, shows no consistent relation to width nor to sinuosity index. A reach having a mean width of about 50 feet has the steepest slope (0.0016), and another reach having the same mean width has the gentlest slope (0.0008). Along many of the 10,000-foot reaches, the river shows little variation in width, and any significant difference in slope between uniformly narrow reaches and uniformly wide reaches would have been recorded by the 10 -foot contours. Like the Middle Loup at Dunning, the Calamus River evidently adjusts from wide sections to narrow sections not by change in slope but by change in effective crosssectional area. Valley slope, as measured along a line that passes through the inflection points of river bends, also shows no consistent relation to width or to sinuosity index.

Figure 25 shows the relation between width and sinuosity index. Inasmuch as slope and discharge are nearly uniform, width may be regarded as the practical measure of bank erodibility-the wider a section, the more erodible its banks. Low sinuosities are asso- 


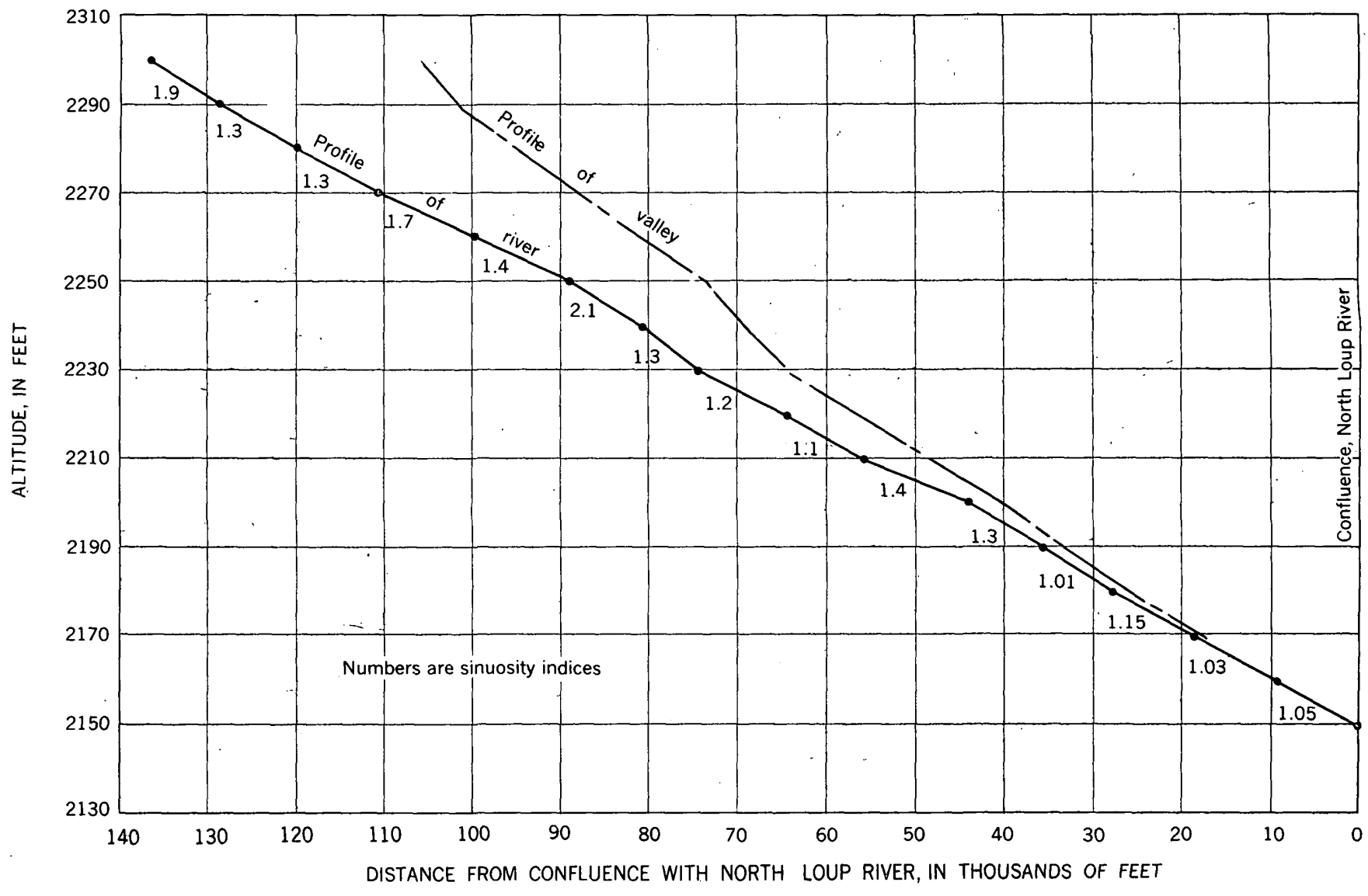

Fiavro 24.-Longitudinal river profle and valley profle, Calamus River, Nebr. Profile extends 25 miles upstream from confluence with North Loup River.

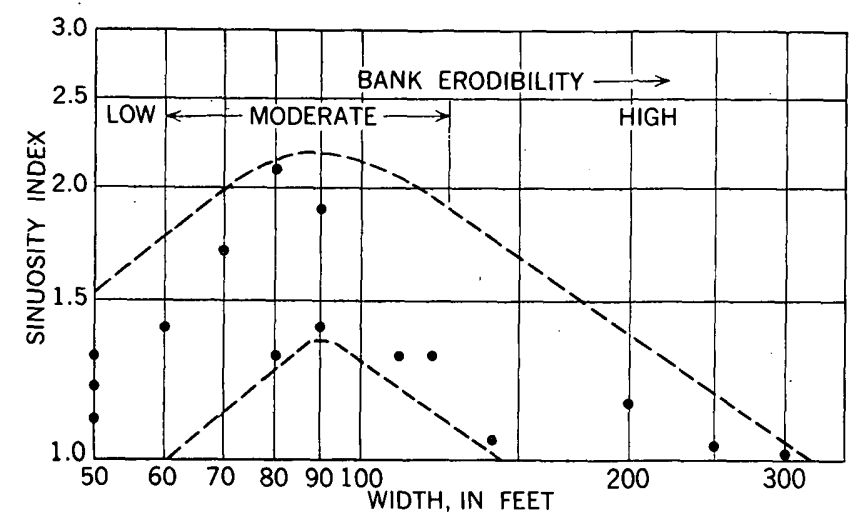

Figure 25.-Diagrammatic relation of sinuosity index to width and bank erodibility, Calamus River. Width is regarded as a practical measure of bank erodibility.

ciated with high and low bank erodibilities, and high sinuosities are associated with intermediate bank erodibilities.

The relations among channel pattern, bank erodibility, and slope along the Calamus River, as interpreted by the writer, are summarized as follows: For a given discharge, channel pattern is determined mainly by bank erodibility and valley slope. Differ- ences in bank erodibility are mainly determined by vegetal growth along the banks. Valley slope is mainly predetermined by regional slope and by the slope of the Elba terrace. A moderate degree of bank erodibility, controlled by swamp vegetation in the upper part of the river segment under consideration, led to the development of a meandering pattern and a moderately narrow width. Along reaches where vegetal resistance to bank erosion was high, the river course is nearly straight and tends to be narrow. Along reaches having low vegetal resistance to bank erosion, as in the lower part of the segment, the river developed a broad, shallow, and somewhat braided course. The general slope of the long river profile is rather uniform, and hydraulic adjustment to local variations in width is mostly made by changes in crosssectional area rather than by changes in slope.

Friedkin (1945) attributed changes in channel pattern along the length of the Mississippi River to differences in bank erodibility. His experiments with small-scale rivers showed that entirely resistant banks led to the development of a deep, narrow channel having a flat channel slope and that less resistant banks 
led to a slowly meandering channel having a moderately flat slope. A braided pattern having steep slopes was developed where banks were very erodible.

Friedkin's conclusions apply satisfactorily to the Loup Rivers except that a braided reach may have an only slightly greater channel slope than a meandering reach of nearly the same discharge. Also, a lush growth of vegetation may serve to confine a stream between otherwise erodible banks.

\section{DISCHARGE}

Leopold and Wolman (1957) tentatively concluded that channel width is mainly a function of discharge and that the quasi-equilibrium width of a channel is determined by bank-full or barely overbank discharges. Width also is related to average discharge. Leopold and Maddock (1953) showed that, for many rivers, width increases downstream as the 0.5 power of average discharge. The Loup River system is exceptional among the eight rivers plotted by Leopold and Maddock, inasmuch as width increases downstream as the 0.75 power of average discharge.

The concept of bank-full discharge is difficult to apply to the upper reaches of the Loup Rivers, which have such constancy of discharge that they rarely attain the bank-full stage. In addition, the Loup Rivers are bordered by a series of low terraces of different heights. The height of the river banks varies from place to place and depends on which terrace level the river has cut against laterally. For an approximation of bank-full discharge, an average of the maximum daily mean discharges for the years of available record during the period 1946-57 was computed for each gaging station. For some stations, only 2 years of record was available for the period. (See table 2.) For those reaches attaining a bank-full or overbank stage, the average of the maximum daily mean discharges agrees reasonably well with the bank-full discharge as estimated from gage heights.

For the Loup Rivers, mean width was plotted against average discharge and also against bank-full discharge. Very different results were obtained from the two plots. Width increases for each river according to the following powers of average discharge: South Loup, 1.8; Middle Loup, 1.3; and North Loup, 0.7. Width increases for each river according to the following powers of bank-full discharge: South Loup 0.6 ; Middle Loup, 0.8 ; and North Loup, 0.45. In general, therefore, bank-full width increases at a greater rate relative to average discharge than to bank-full discharge.

Figure 26 shows the relation of width to mean annual discharge and bank-full discharge for Loup River reaches at the gagin stations listed in table 2 . When all points on the plot are considered, the visually approximated curve for meandering reaches has a slope of about 0.5. The point representing the Middle Loup near Seneca does not fall on this curve. However, the measurements for the Middle Loup near Seneca were made on a topographic map of scale 1:62, 500 whereas measurements for the other reaches were made on aerial photographs. Points representing braided or sinuous reaches and straight reaches are widely scattered; but the widths represented are generally greater than the widths of meandering reaches. Much of the scatter of points is attributed to the pronounced local variation in width that is characteristic of the North Loup and Middle Loup. This variation in width is, in turn, attributed to banks whose erodibility is high insofar as particle size is concerned but whose erodibility is much decreased locally by vegetation.

Variability of discharge is a possible factor in the development of channel pattern and river width. A rought measure of variability of discharge was obtained by relating the discharge for the month having the highest flow during a water year to the discharge for the month having the lowest flow. For the period 1946-57, averages were computed for the maximum monthly discharges and for the minimum monthly discharges. The mean deviation of the average monthly maximums and minimums (relative to the average discharge for the period of record) was divided by the average discharge to give a coefficient of deviation of discharge. (See table 2.) An accurate variability index, such as that proposed by Mitchell (1957), requires the use of flow-duration curves, which are not available for the Loup Rivers.

For the Loup Rivers, no direct relation between variability of discharge and channel pattern is apparent, but variability of discharge may have a significant effect on increase in width with downstream increase in discharge. The channel pattern of the Calamus River changes greatly along the last 25 miles of its course despite the fact that variability of discharge is low and constant. The reach having the highest coefficient of deviation of discharge (1.06 for the South Loup River at St. Michael) is meandering, and many reaches in the upper Middle Loup that have low coeffcients of devaition (probably less than 0.2) are also meandering. Downstream increase in width with increasing average discharge-higher for the Loup Rivers than for other rivers plotted by Leopold and Maddock (1953)-may perhaps be attributed to the downstream increase in variability of discharge shown by the Loup Rivers (table 2). River width increases not only with downstream inerease in all measures of 


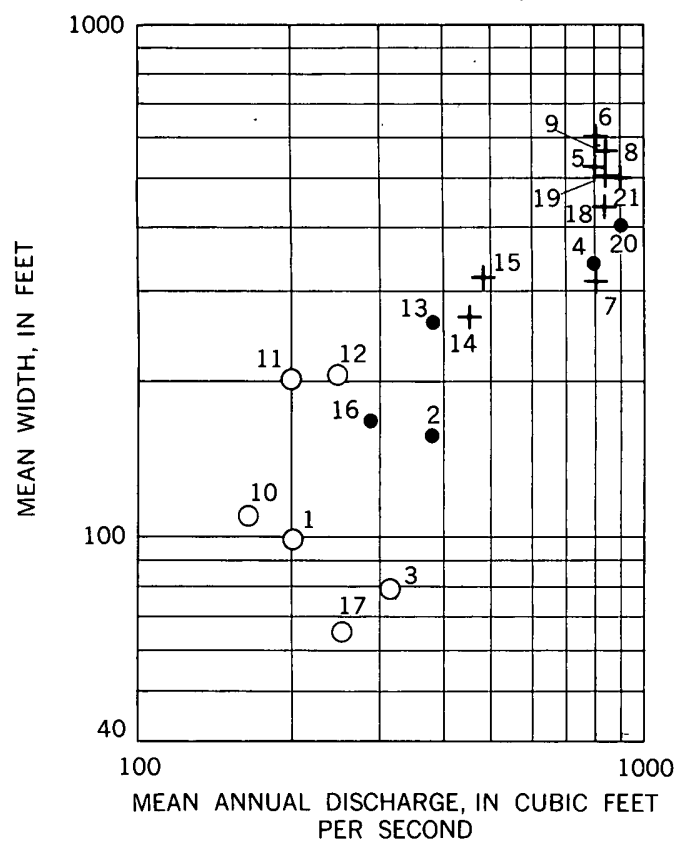

+ Braided reach, total B. I. $\geq 1.5$

- Reach having B.I. $<1.5$, S. I. $<1.3$

O Meandering reach, S. I. $\geq 1.3$

$\uparrow$ Standard deviation of width

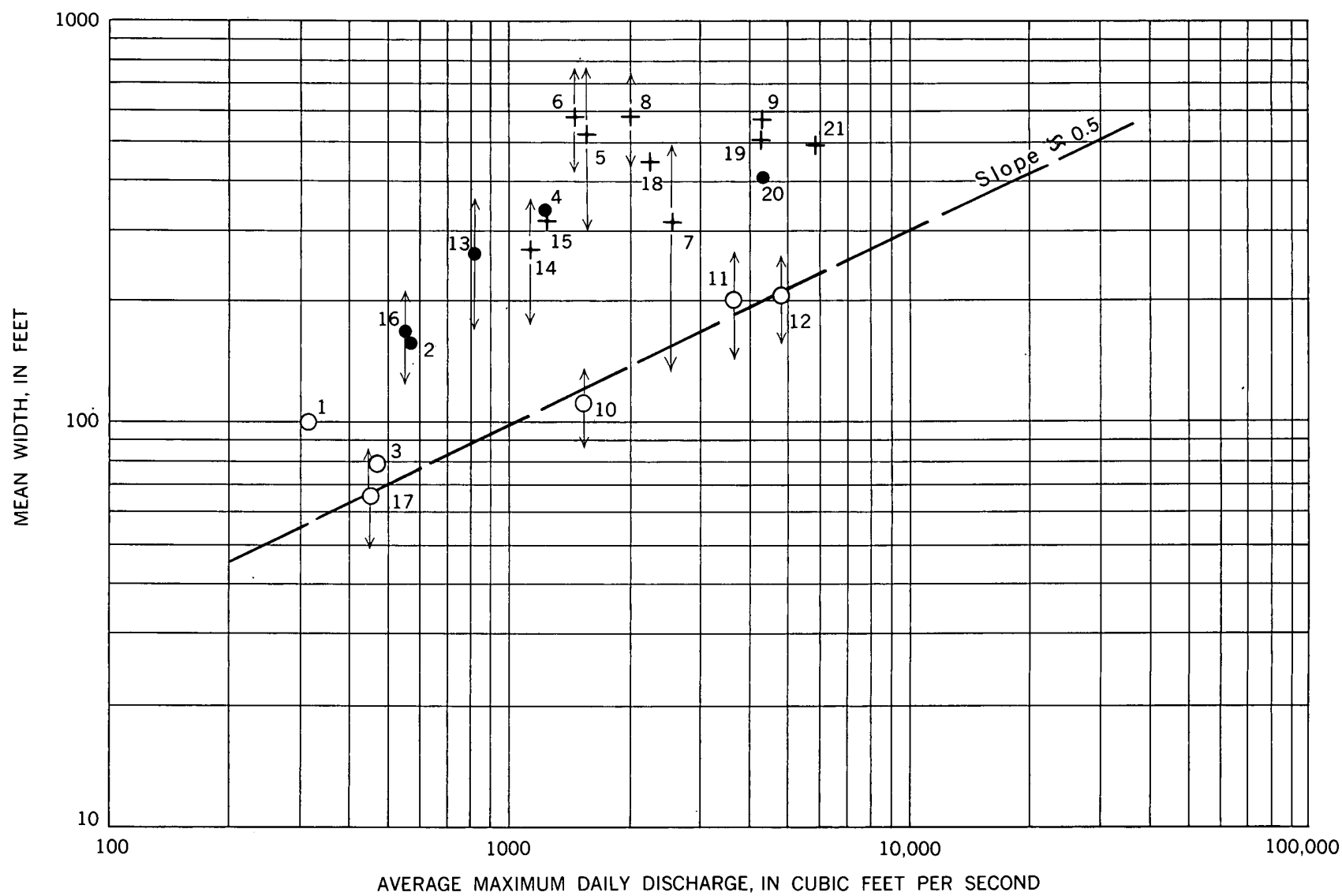

FIGURE 26.-Width in relation to mean annual discharge and average maximum daily discharge (approximately bank-full discharge) for different channel patterns. Numbers refer to gaging stations listed in table 2. 
discharge but also with increase in bank-full discharge relative to average discharge.

\section{BED MATERIAL AND SUSPENDED-SEDIMENT CONCENTRATION}

In the northern part of the Loup River basin, where the flow of the Loup Rivers is derived mainly from ground water rather than from surface runoff, the rivers derive most of their total sediment load from bank erosion. Any material supplied by surface runoff is fine- or meduim-grained sand because the ground is almost entirely mantled by dune sand. In the loessmantled southern part of the basin, surface runoff makes substantial contributions to streamflow, and the sediment supplied is mainly silt.

J. C. Busby (written communication, Nebraska Univ. 1950) investigated the bed material, particularly the sands, of the Middle Loup River. The bed material was sampled at depths ranging from 1 inch to 10 feet by driving an iron casing into the river bed at seven locations. Penetration by the casing into the bed at some of the sampling points was halted by coarse gravel or clay at a depth of about 5 feet, but the river bed at most points was free of gravel to a depth of at least 9 feet. In general, the median diameter of the sand increases somewhat as the depth below the surface of the stream bed increases. A typical increase is shown by the sampling of the Middle Loup River near Loup City in that the median diameter of bed material is about 200 microns in the first foot and about 400 microns in the ninth foot.

Busby computed the average median diameter for the first 3 feet in each cross section and plotted the results to show downstream changes. The averages were 0.27 millimeter at Thedford, 0.38 millimeter at Dunning, 0.25 millimeter at Walworth, 0.26 millimeter at Loup City, and 0.29 millimeter at Rockville. Very little sand coarser than 0.8 millimeter was found in any of the samples. In general, the bed material is well sorted, and the size distribution is only slightly skewed.

In their report on sediment transportation in the Middle Loup River at Dunning, Hubbel and Matejka (1959) discussed size analyses of bed material taken with a piston-type sampler from cores about 2 inches in diameter and about 6 inches in length. For the coarest of 187 samples analyzed, 80 percent of the material was finer than 4 millimeters and 27 percent was finer than 0.5 millimeter. The samples were collected at irregular intervals between September 1949 and September 1952.

Bed material has been sampled by the Geological Survey at four stations along the North Loup over periods ranging from 1 year at Cotesfield to 4 years at Burwell. For the South Loup River, bed material has been sampled only at St. Michael. Analyses of 24 samples collected by the Geological Survey during 1952 and 1953 indicate that the bed material of the South Loup is mainly fine- to medium-grained sand. Bed material of the South Loup is somewhat finer than that of the North Loup or Middle Loup, but all three rivers have sandy beds.

Averages of particle-size analyses of bed material from the Loup Rivers are shown in table 2. According to these analyses, most of the bed material of the Loup Rivers is medium- or fine-grained sand; there is little difference in size of bed material from one river to the next or from place to place along the same river.

Even where the Loup Rivers appear to be only slightly turbid, the suspended-sediment discharge is obviously a significant part of the total sediment discharge. The measured suspended-sediment discharge of the Middle Loup River at Dunning, where the river appears to be clear rather than muddy, averages about one-half of the total sediment discharge as measured at the turbulence flume (Hubbell and Matejka, 1959). Average suspended-sediment concentrations, in parts per million, were computed for each station by J. C. Mundorff of the Quality of Water Branch in Lincoln, Nebr. The South Loup River, which exhibits the most consistently meandering pattern, also has the highest suspended-sediment concentration. The average amount of clay (particles less than $0.004 \mathrm{~mm}$ in diameter) in the suspended sediment of the South Loup River at Cumro is about 24 percent, whereas the average amount for stations on the North Loup and Middle Loup is about 9 percent.

Schumm (1963, p. 1094) suggested that the silt-clay content of the bed and banks may be representative of the type of sediment load transported by a stream. The higher the percentage of total sediment load transported as wash load (silt and clay), the higher is the silt-clay content of bed and banks and the more sinuous is the stream likely to be. This suggestion seems valid and it is supported by comparison of the South Loup with the North Lnup and Middle Loup. Unfortunately, information on total sediment load is not available for most rivers.

The braided pattern is sometimes attributed to an excess of total load supplied to the stream-that is, to a supply of sediment that exceeds the capacity of the stream. The capacity of a stream is difficult to determine either by theory or by measurement. An excess of total load might be indicated by aggradation, and no excess of total load might be indicated by degradation. Geological evidence indicates that the Loup Rivers are slowly degrading. 


\section{WATER TEMPERATURE}

Hubbell (1960, p. 22) discussed the significant influence of water temperature on the hydraulics of the Middle Loup River at Dunning. Dune heights on the river bed become distinctly lower as water temperature decreases, and the bed is smoothest at water temperatures near $32^{\circ} \mathrm{F}$. Small sediment discharges and large flow resistances are associated with high temperatures whereas large sediment discharges and small flow resistances are associated with low temperatures. Hubbell also noted that the shallowest depths, narrowest widths, and highest velocities are associated with the lowest temperatures.

Figures 27 shows the relation of suspended-sediment concentration to water temperature and discharge at sections A, E, and B on the Middle Loup at Dunning. Data from Hubbell and Matejka (1959) were grouped according to temperature and discharge, and means of the groups were plotted. Means of water temperature applied to measurements grouped according to successive $10^{\circ} \mathrm{F}$ temperature intervals, beginning with the interval $30^{\circ}-40^{\circ} \mathrm{F}$. Within each temperature interval, means of mean suspended-sediment concentration were based on measurements grouped according to discharge. For example, a mean was computed for all suspended-sediment concentrations listed for discharges of 350-399 $\mathrm{cfs}$ at water temperatures of $40^{\circ}$ $49^{\circ}$ F. For a given discharge range, suspended-sediment concentration decreases sharply as temperature increases.

Figure 28 shows the relation of velocity to water temperature and discharge at sections $\mathrm{A}$ and $\mathrm{E}$. Means of the variables were grouped as described for figure 27. The decrease in velocity with increase in temperature accounts for part of the scatter of points in figure 15, for which temperature was not taken into account.

For the Middle Loup at Dunning, temperature has a significant effect on suspended-sediment concentration and velocity as well as an effect (probably indirect) on bed form; however, these effects do not necessarily apply to streams in general. Because much of the suspended sediment in the Middle Loup is fine sand, increase in viscosity with decrease in temperature has a significant effect on the vertical distribution of suspended sediment. For streams whose suspended sediment is mostly silt and clay, increase in viscosity has less effect on vertical distribution of suspended sediment. The change in bed form of the Middle Loup is probably related to a slight change in velocity through a critical value, above which dunes are built and below which dunes are flattened. For other streams, change in temperature might not cause velocity to change through this critical value.

A measurable effect of temperature on channel pattern and slope might be expected because of the significant influence of temperature on Loup River hydraulics. The measurements at sections $\mathrm{A}$ and $\mathrm{E}$ on the Middle Loup at Dunning were analyzed to detect any effect of temperature on effective width, effective area, or slope. The number of measurements made at similar discharges for the whole range of water temperatures was insufficient for any definite conclusions to be drawn. However, both effective

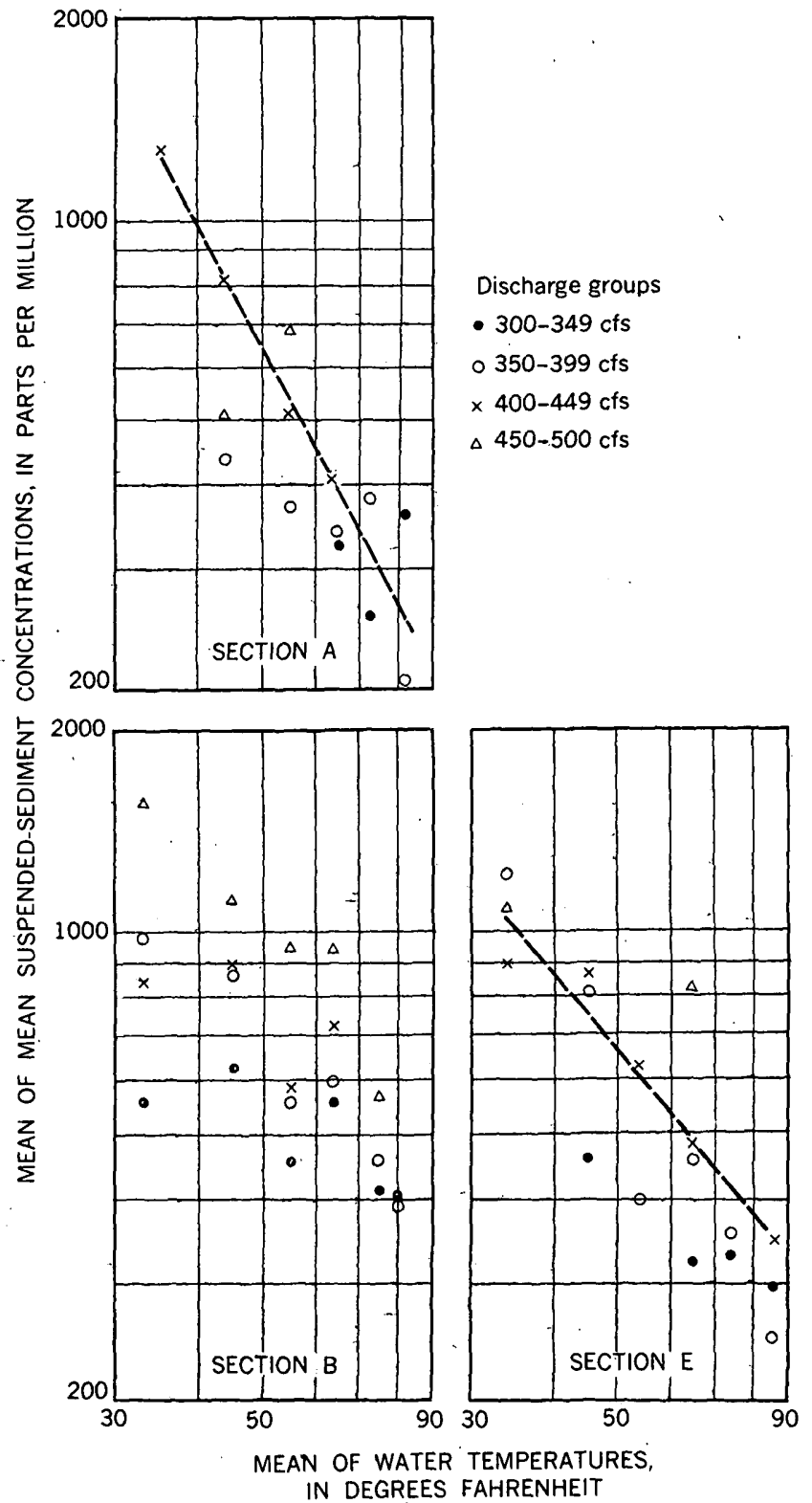

Figdre 27.-Suspended-sediment concentration in relation to temperature and discharge, sections $A, E$, and $B$, Middle Loup River at Dunning, Nebr. 


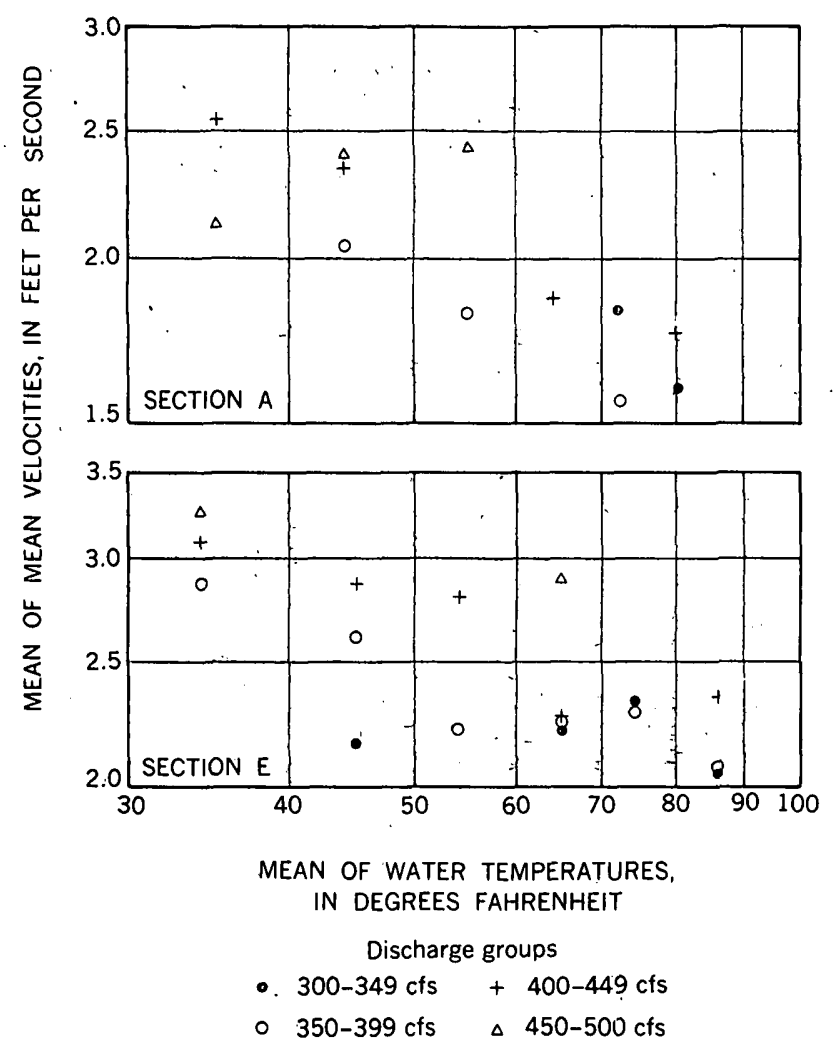

Fravro 28.-Velocity in relation to temperature and discharge, sections $\mathbf{A}$ and $\mathbf{E}$, Middle Loup River at Dunning, Nebr.

width and effective area show a general tendency to increase as temperature increases. At section $\mathbf{A}$, for discharges in the range of $400-449 \mathrm{cfs}$, mean effective width increases by 20 percent as water temperature increases from $35^{\circ}$ to $65^{\circ} \mathrm{F}$, and mean effective area increases by 30 percent. At section $\mathrm{E}$, for discharges in the range of $350-399 \mathrm{cfs}$, mean effective width does not change as temperature increases from $34^{\circ}$ to $74^{\circ} \mathrm{F}$, but effective area increases by 21 percent. Changes in local slope could not be related to changes in water temperature. In spite of the influence of temperature on width at section A. there is nevertheless a significant correlation of width to effective area, mean velocity, and maximum depth. (See fig. 15.)

\section{LONGITUDINAL RIVER SLOPE AND VALLEY SLOPE}

Inspection of figures 8,9 , and 10 shows that the longitudinal river profiles of the North, South, and Middle Loup Rivers are nearly straight except for some steepening in the upper reaches and some flattening in the lower reaches: River profiles of the North Loup and Middle Loup are similar in slope, but in valley profile the Middle Loup is slightly steeper than the North Loup. The general river slope of the South Loup (0.0011 ft per $\mathrm{ft}$ ) is somewhat gentler than that of the Middle Loup ( $0.00125 \mathrm{ft}$ per $\mathrm{ft})$. The general valley slope of the South Loup $(0.0018 \mathrm{ft}$ per $\mathrm{ft})$ is steeper than that of either the Middle Loup or North Loup. General straightness of the river profiles is attributed mainly to the straightness of the predetermined slope over which the rivers flow-the slope of the Great Plains.

Because of the near constancy of slope that accompanies a significant variation in discharge and channel pattern, no good correlation of slope with discharge and channel pattern would be expected. However, river slopes of the 9,600-foot reaches at gaging stations were measured on topographic maps and plotted against bank-full discharge (fig. 29). The plot shows that the slopes of most meandering reaches are less than the slopes of most braided reaches of similar discharge. The points for both meandering and braided reaches represent an insufficient range in slope and discharge for any general relations to be established. Also, channel width should be taken into account simultaneously with the other variables. Indeed, analysis of channel characteristics of the Middle Loup at Dunning indicates that local slope shows little or no correlation with any variable except width.

For a given discharge and size of bed material, braided reaches of rivers in general probably have steeper channel slopes and greater effective widths than meandering reaches. Lane (1957) plotted slopedischarge relations for meandering sandbed streams, for braided sandbed streams, and for streams in gravel. $\mathrm{He}$ proposed that, for streams in each of these categories, slope varies inversely as the fourth root of average discharge. Also, meandering sandbed streams have lower slopes than braided sandbed streams of the same average discharge. Leopold and Wolman (1957) plotted channel slope against bank-full discharge for rivers that represent a wide range of discharges and bed-bank materials. A line, whose slope varies inversely as the 0.44 power of discharge, separates meandering streams from braided streams on their plot; and meandering streams have lower slopes than braided streams of similar bank-full discharge.

Lane (1957, p. 36) discussed the influence of valley slope on channel pattern. According to one viewpoint, a river meanders on a steep slope to reduce channel slope to an equilibrium value; therefore, the steeper the valley slope, the more sinuous the channel. Lane argued against this viewpoint; he maintained that steep valley slopes promote the braided pattern and that low valley slopes promote the meandering pattern. The lower the valley slope, the more sinuous the stream is likely to be, except that the sinuosity may be again reduced on very low slopes. 


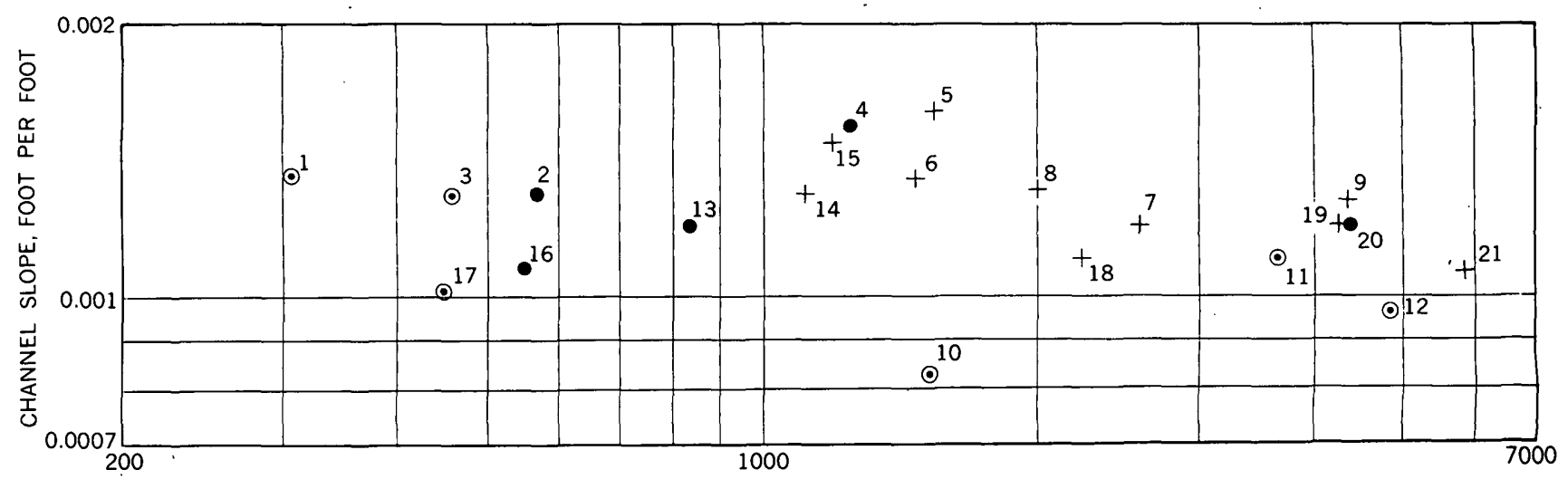

AVERAGE MAXIMUM DAILY DISCHARGE, IN CUBIC FEET PER SECOND

$+\quad$ Braided reach, total B. I. $\geq 1.5$

- Reach having B. I. $<1.5$, S. I. $<1.3$

$\odot \quad$ Meandering reach, S. I. $\geq 1.3$

Figure 29.- Reach slope in relation to the average maximum dally discharges for meandering and braided reaches. Numbers refer to gaging stations listed in table 2.

Experiments were done by Friedkin (1945, p. 10), to investigate the effect of valley slope on sinuosity. Within the range of slopes used in the experiments (0.006-0.009), sinuosity (and also the length and width of individual bends) increased as valley slope increased. However, the rate of increase in sinuosity was much reduced as the slopes became higher, and further increase in valley slope would perhaps have resulted in a decrease in sinuosity.

No generalities about the relation between valley slope and channel pattern are valid without the specification of other variables, of which bank erodibility, bed material, and discharge are probably the most significant. Under suitable conditions, streams will meander on steep slopes. For example, Leopold and Wolman (1960, p. 774) described a meandering channel having a slope of 0.023 and a discharge of about 2.4 cfs that was carved in glacier ice by streams of melt water flowing on the glacier surface. Dury (1959) described meandering gullies on a steep-sided "spoilheap." Relations between discharge and bank erodibility that are favorable for development of the meandering pattern probably cause development of maximum sinuosity at some optimum value of valley slope and cause a decrease in sinuosity at slopes both greater and smaller than this optimum value.

The reach of the South Loup that is on the steepest segment of the longitudinal valley profile (fig. 10) has the lowest sinuosity index. Elsewhere, the valley slope is nearly constant, but different reaches have considerably different sinuosities. The differences in sinuosity are attributed to local differences in bank erodibility. For a given valley slope, river slope necessarily decreases as sinuosity increases. Because the valley slope of the South Loup is nearly constant upstream from the steep segment of its profile, the river slope upstream from this segment decreases as sinuosity index increases.

\section{REFERENCES CITED}

Condra, G. E., Reed, E. C., and Gordon, E. D., 1950, Correlation of the Pleistocene deposits of Nebraska: Nebraska Geol. Survey Bull. 15A, p. 1-2.

Dury, G. H., 1959, The face of the earth: Baltimore, Md., Penguin Books, 223 p.

Friedkin, J. F., 1945, A laboratory study of the meandering of alluvial rivers: Vicksburg, Miss., U.S. Waterways Expt. Sta., $40 \mathrm{p}$.

Frye, J. C., Leonard, A. B., and Swineford, Ada, 1956. Stratigraphy of the Ogallala formation (Neogene) of northern Kansas: Kansas Geol. Survey Bull. 118, p. 1-92.

Hubbell, D. W., 1960, Investigations of some sedimentation characteristics of sand-bed streams, Progress reports : U.S. Geol. Survey open-file rept., 78 p., 15 figs.

Hubbell, D. W., and Matejka, D. Q., 1959, Investigations of sediment transportation, Middle Loup River at Dunning, Nebraska: U.S. Geol. Survey Water-Supply Paper 1476, $123 \mathrm{p}$. 
Lane, E. W., 1957, A study of the shape of channels formed by natural streams flowing in erodible material: U.S. Army Corps of Engineers, Missouri River Div., Omaha, Nebr., Sediment Ser. 9, 106 p., 15 figs.

Iueopold, L. B., and Maddock, Thomas, Jr., 1953, The hydraulic geometry of stream channels and some physiographic implications: U.S. Geol. Survey Prof. Paper $252,57 \mathrm{p}$.

Leopold, L. B., and Wolman, M. G., 1957, River channel patterns-braided, meandering, and straight: U.S. Geol. Survey Prof. Paper 282-B, 85 p.

1960, River meanders: Geol. Soc. America Bull., v. 71, p. 769-794.

Miller, J. P., 1958, High mountain streams-effect of geology on channel characteristics and bed material: New Mexico Inst. Mining and Technology Mem. 4, $53 \mathrm{p}$.

Miller, R. D., and Scott, G. R., 1955, Sequence of alluviation along the Loup Rivers, Valley County area, Nebraska: Geol. Soc. America Bull., v. 66, p. 1431-1448.
Miller, R. D., and Scott, G. R., 1961, Late Wisconsin age of terrace alluvium along the North Loup River, central Nebraska-a revision: Geol. Soc. America Bull., v. 72, p. 1283-1284.

Mitchell, W. D., 1957, Flow duration of Illinois streams: Springfield, Illinois Dept. Public Works and Buildings, Div. Waterways, $189 \mathrm{p}$.

Rubey, W. W., 1952, Geology and mineral resources of the Hardin and Brussels quadrangles (in Illinois): U.S. Geol. Survey Prof. Paper 218, 179 p.

Schumm, S. A., 1960, The effect of sediment type on the shape and stratification of some modern fluvial deposits: Am. Jour. Sci., v. 258, p. 177-184.

1963, Sinuosity of alluvial rivers of the Great Plains: Geol. Soc. America Bull., v. 74, p. 1089-1100.

Simith, H. T. U., 1955, Use of aerial photography for interpretation of dune history in Nebraska, U.S.A.: Internat. Congr., 4th, Rome-Pisa 1953, Assoc. for Study of the Quaternary, $7 \mathrm{p}$. 